\title{
PURIFICAÇÃO PARCIAL DE ELICITORES PRESENTES EM Saccharomyces cerevisiae: ATIVIDADE COMO INDUTORES DE RESISTÊNCIA EM PEPINO (Cucumis sativus) CONTRA Colletotrichum lagenarium E DA SÍNTESE DE GLICEOLINAS EM SOJA (Glycine max)
}

\section{ELAINE REGINA GODOY LABANCA}

Dissertação apresentada à Escola Superior de

Agricultura "Luiz de Queiroz", Universidade de São Paulo, para obtenção do título de Mestre em Agronomia, Área de concentração: Fitopatologia.

PIRACICABA

Estado de São Paulo - Brasil

Maio - 2002 


\section{PURIFICAÇÃO PARCIAL DE ELICITORES PRESENTES EM Saccharomyces cerevisiae: ATIVIDADE COMO INDUTORES DE RESISTÊNCIA EM PEPINO (Cucumis sativus) CONTRA Colletotrichum lagenarium E DA SÍNTESE DE GLICEOLINAS EM SOJA (Glycine max)}

\section{ELAINE REGINA GODOY LABANCA}

Engenheiro Agrônomo

Orientador: Prof. Dr. SÉRGIO FLORENTINO PASCHOLATI

Dissertação apresentada à Escola Superior de

Agricultura "Luiz de Queiroz", Universidade de São Paulo, para obtenção do título de Mestre em Agronomia, Área de concentração: Fitopatologia.

PIRACICABA

Estado de São Paulo - Brasil

Maio - 2002 


\section{Dados Internacionais de Catalogação na Publicação (CIP) DIVISÃO DE BIBLIOTECA E DOCUMENTAÇÃO - ESALQ/USP}

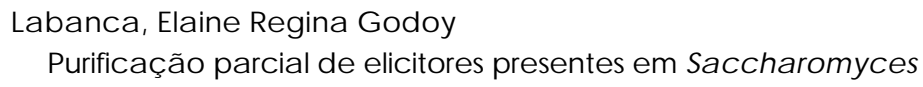
sa tivus) contra Colletotric hum lagena rum e da síntese de gliceolinas em soja (Glycine max) / Ela ine Regina Godoy Labanca. - - Piracicaba, 2002.

$107 \mathrm{p}$.

Dissertação (mestrado) - - Escola Superior de Agricultura Luiz de Queiroz, 2002.

Bibliografia.

1. Fitoalexinas 2. Pepino 3. Peroxidase 4. Saccharomyces 5. Soja I. Título

CDD 635.63

\section{"Permitida a cópia total ou parcial deste documento, desde que citada a fonte - $\mathrm{O}$ autor'}


Ao André, ao Guilherme e ao Felipe Aos meus pais 


\section{AGRADECIMENTOS}

Ao professor Sérgio F. Pascholati pelo acolhimento, e orientação.

Aos colegas do Laboratório de Fisiologia e Bioquímica Fitopatológica - ESALQ/USP: André, Ana Carolina, Célia, Eduardo, Renata, Robson e, em especial: Júlio, Nélson e Nívea.

A Silvia, do Laboratório de Epidemiologia, pelas muitas horas no leitor de área foliar.

Ao amigo César Ricardo Silva (Instituto de Química da Universidade Estadual de Campinas) pela análise espectromética.

A Fundação de Amparo à Pesquisa do Estado de São Paulo (FAPESP) pelo apoio financeiro ao projeto. 


\section{SUMÁRIO}

Página

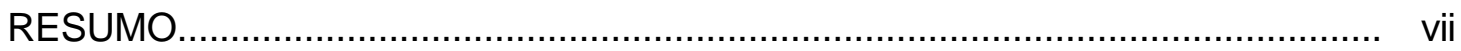

SUMMARY

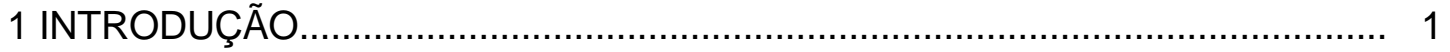

2 REVISÃO DE LITERATURA............................................................... 3

2.1 Aspectos gerais da indução de resistência.................................................... 3

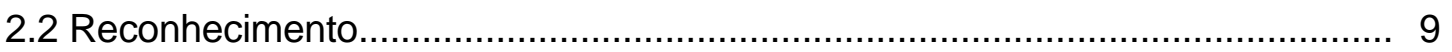

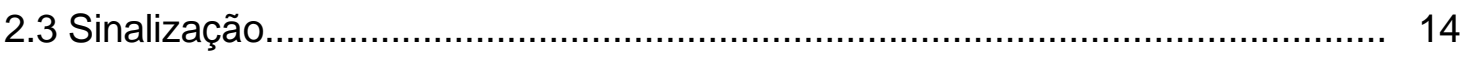

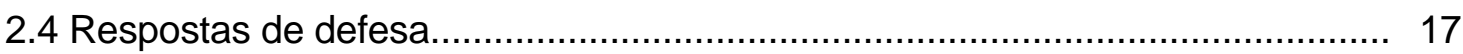

2.4.1 Explosão oxidativa e reação de hipersensibilidade.................................... 20

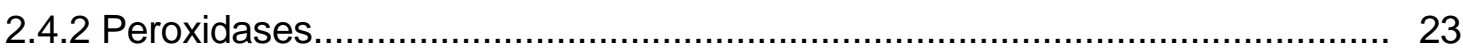

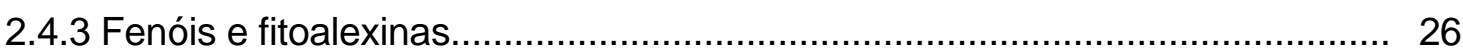

2.5 Saccharomyces cerevisiae e a indução de resistência.................................... 32

3 MATERIAL E MÉTODOS.......................................................................... 36

3.1 Extração e purificação dos elicitores.............................................................. 36

3.2 Determinação do conteúdo de carboidratos e proteínas................................... 38

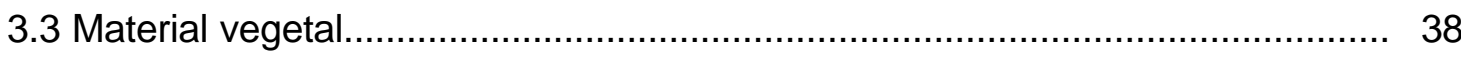

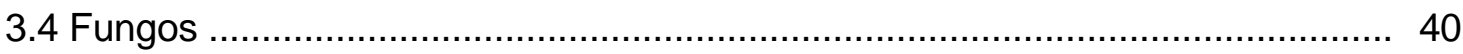

3.5 Pepino - Produção das plantas, tratamento e inoculação................................ 40

3.6 Determinação da concentração de fenóis livres e ligados................................ 42

3.7 Determinação da atividade de peroxidases.................................................... 43

3.8 Soja - Produção das plantas, tratamento e inoculação...................................... 43 
3.9 Bioensaios com cotilédones de soja........................................................ 45

3.10 Teste de fungitoxidez in vitro ......................................................... 45

3.11 Caracterização espectrofotometrica/ espectrometrica dos elicitores................ 46

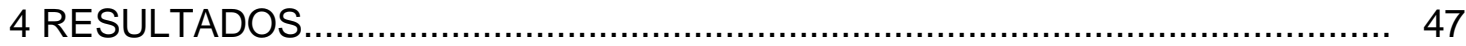

4.1 Purificação dos elicitores............................................................................. 47

4.2 Ensaios de proteção com pepino.............................................................. 50

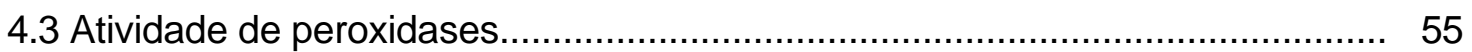

4.4 Concentração de fenóis livres e ligados....................................................... 56

4.5 Bioensaios com cotilédones de soja..................................................... 57

4.6 Ensaios de proteção com plantas de soja.................................................... 59

4.7 Testes de fungitoxidez in vitro................................................................. 61

4.8 Caracterização espectrofotometrica/ espectrometrica dos elicitores................ 63

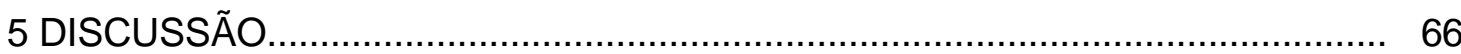

5.1 Métodos para extração dos elicitores........................................................... 66

5.2 Indução de resistência em pepino............................................................. 68

5.3 Acúmulo de fenóis ............................................................................ 70

5.4 Atividade de peroxidases...................................................................... 72

5.5 Testes de fungitoxidez in vitro............................................................... 74

5.6 Indução de resistência e de fitoalexinas em soja............................................ 75

5.7 Caracterização espectrofotometrica/ espectrometrica dos elicitores................. 78

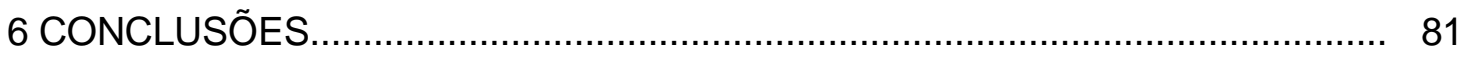

ANEXO

REFERÊNCIAS BIBLIOGRÁFICAS.............................................................. 84

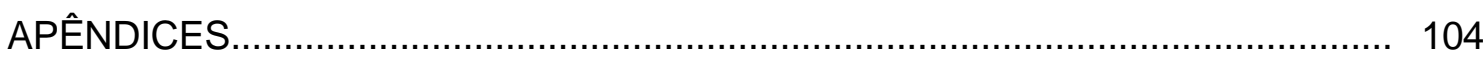




\title{
PURIFICAÇÃO PARCIAL DE ELICITORES PRESENTES EM Saccharomyces cerevisiae: ATIVIDADE COMO INDUTORES DE RESISTÊNCIA EM PEPINO (Cucumis sativus) CONTRA Colletotrichum lagenarium E DA SÍNTESE DE GLICEOLINAS EM SOJA (Glycine max)
}

\author{
Autora: ELAINE REGINA GODOY LABANCA \\ Orientador: Prof. Dr. SÉRGIO FLORENTINO PASCHOLATI
}

\section{RESUMO}

A indução de resistência em plantas contra fitopatógenos é um método alternativo de controle de doenças, o qual envolve a ativação de mecanismos de resistência latentes da planta. Hoje no mercado existem poucos produtos que atuam segundo este princípio. Na busca de novas moléculas que possam ser utilizadas em campo, diversos compostos de origem microbiana, com capacidade de estimular uma ou mais respostas de defesa, já foram isolados e caracterizados. A Saccharomyces cerevisiae é uma levedura capaz de induzir resistência e elicitar respostas de defesa em algumas plantas. Com o objetivo de extrair da levedura um ou mais compostos capazes de induzir o acúmulo de fitoalexinas em cotilédones de soja e na proteção dessa leguminosa contra Microsphaera diffusa (agente causal do oídio da soja) e de pepino contra Colletotrichum lagenarium (agente causal da antracnose do pepino), células em suspensão foram autoclavadas. Os compostos assim extraídos foram inicialmente separados através de precipitação etanólica. Em seguida, foram 
realizadas cromatografias de troca iônica e de afinidade para separar as frações com maior poder elicitor das de baixo poder elicitor. $A$ fração não adsorvida àresina $D E A E-$ Celulose foi a que induziu maior acúmulo de fitoalexinas. No entanto, nenhum dos preparados testados foi capaz de conferir proteção a plantas de soja contra M. diffusa. Já no caso de pepino, plântulas tratadas com as frações resultantes da cromatografia de afinidade apresentaram reduções entre 50 e $70 \%$ de área lesionada causada por C. lagenarium e aumento na atividade de peroxidases. Extratos incorporados à meio de cultivo não apresentaram efeito inibitório sobre o crescimento e esporulação de $C$. lagenarium. Com base nesses resultados, concluímos que existe na parede da levedura compostos capazes de induzir resistência local em pepino contra $C$. lagenarium, sendo que pelo menos um destes compostos é um carboidrato, contendo provavelmente manana e glucosamina. 


\title{
PARTIAL PURIFICATION OF ELICITORS FROM Saccharomyces cerevisiae: ROLE AS RESISTANCE INDUCERS IN CUCUMBER (Cucumis sativus) AGAINST Colletotrichum lagenarium AND AS INDUCERS OF GLYCEOLLIN SYNTHESIS IN SOYBEAN (Glycine max)
}

\author{
Author: ELAINE REGINA GODOY LABANCA \\ Adviser: Prof. Dr. SÉRGIO FLORENTINO PASCHOLATI
}

\section{SUMMARY}

The acquired resistance of plants to pathogens is an alternative method to control diseases which includes the activation of resistance mechanisms in the plants. A few products already commercially available have their action based upon this mechanism. In the search for novel molecules that can be used under field conditions, many compounds from microbes with the ability to stimulate one or more defense responses were already isolated and characterized. Saccharomyces cerevisiae is an yeast with the ability to induce defense responses and resistance in some plants. A suspension of cells from the yeast was autoclaved with the purpose of extracting one or more compounds with the ability to induce the accumulation of phytoalexins in soybean cotyledons and to protect soybean plants against Microsphaera diffusa (causal agent of powdery mildew) and plants of cucumber against Colletotrichum lagenarium (causal agent of anthracnose). The compounds extracted by this method were 
separated using ethanolic precipitation. After this step, the fractions of higher elicitation activity were separated from those of lower one by using ion exchange cromatography and affinity cromatography. The non-adsorbed fraction to DEAE-Cellulose was the one that induced the highest accumulation of phytoalexins. However, none of the fractions were able to protect soybean plants from $M$. diffusa. In the case of cucumber, seedlings treated with the fractions from affinity chromatography were able to reduce disease symptoms caused by $C$. lagenarium by 50 to $70 \%$ and to increase the activity of peroxidases. Extracts that were incorporated into growing media did exhibit any inhibitory effect on in vitro growth and sporulation of $C$. lagenarium. According to these results, it is possible to conclude that there are compounds in the cell walls of the yeast that are able to induce local resistance to $C$. lagenarium in cucumber and that at least one of these compounds is a carbohydrate that likely contains mannan and glucosamine. 


\section{INTRODUÇÃO}

Na natureza, a ocorrência de doenças em plantas é uma exceção. A maior parte dos encontros entre plantas e microrganismos resulta em uma relação incompatível ou seja, não há manifestação de doença. Para que ocorra a doença é necessário um patógeno virulento, uma planta suscetível e um ambiente favorável (Agrios, 1997). Um dos primeiros eventos que ocorre no contato planta-microrganismo é o reconhecimento de um pelo outro. O malogro da infecção pode ser atribuído, pelo menos em parte, ao reconhecimento do possível patógeno pela planta e a ativação de mecanismos de defesa contra o invasor.

O reconhecimento planta-patógeno ocorre normalmente pela interação de uma molécula elicitora do patógeno ou da planta (liberada por ação do patógeno) e de um receptor protéico presente na membrana celular da planta (Cervone et al., 1989, Hahn, 1996; Métraux, 2001; Umemoto et al., 1997). A natureza das moléculas elicitoras é variável sendo mais comum a ocorrência de carboidratos, glicoproteínas, proteínas e lipídios (Ricci et al., 1993; Hahn et al., 1993). A origem das moléculas elicitoras também é variável. Lipopolissacarídeos extracelulares de bactérias, glicoproteínas da parede celular de fungos patogênicos, carboidratos da parede celular de fungos não patogênicos, e proteínas de filtrado de culturas de fungos não patogênicos são alguns exemplos de elicitores purificados ou parcialmente purificados capazes de ativar mecanismos de defesa de plantas (Coventry \& Dubery, 2001; Hahn \& Albersheim, 1978; Koch et al., 1998; Schaffrath et al., 1995; Sejalon-Delmas et al., 1997).

O tratamento de plantas com essas moléculas elicitoras pode levar não apenas a uma resposta de resistência, mas a uma expressão sincronizada de diversos mecanismos de defesa, culminando com o que é chamado de indução de resistência. $\mathrm{O}$ fenômeno de indução de resistência é caracterizado pela transformação de uma relação originalmente compatível entre planta e patógeno numa relação 
incompatível. Um exemplo disso é o indutor de resistência, Messenger ${ }^{\circledR}$, lançado recentemente, e indicado para proteção de diversas plantas contra doenças de origem bacteriana, viral, fúngica, nematóides e insetos (Eden Bioscience, 2001) . O produto é formulado a base de uma proteína da bactéria Erwinia amylovora, agente causador do "fogo bacteriano" em pereira e macieira.

A capacidade de Saccharomyces cerevisiae induzir resistência em plantas contra fitopatógenos já é conhecida. A ação protetora se deve à ativação de mecanismos de defesa das plantas e também à antibiose (Pascholati, 1998). Em trabalho recente, Wulff \& Pascholati (1999) realizaram a purificação parcial e caracterização bioquímica de um elicitor glicoprotéico presente na parede celular da levedura e capaz de induzir a síntese de fitoalexinas em mesocótilos estiolados de sorgo. Hahn e Albersheim (1978), também trabalhando com a levedura, purificaram um carboidrato capaz de induzir a síntese de fitoalexinas em tecido de soja. Segundo os últimos autores citados, esse carboidrato guarda grande semelhança com outro carboidrato, extraído da parede celular de hifas de Phytophthora megasperma f.sp. glycinea, o qual é capaz de induzir a chamada "explosão oxidativa" (produção de espécies ativas de oxigênio, entre elas $\mathrm{H}_{2} \mathrm{O}_{2}$ ) em tecidos de pepino (Svalheim \& Robertsen, 1993). A produção de peróxido de hidrogênio é importante nas reações de defesa da planta, sendo essa atribuída aos seguintes fatos: (1). ação como sinalizador para outras respostas de defesa (Chamnongpol et al., 1998); (2). participação em reações catalizadas por peroxidases que levam a polimerização de fenóis e a formação de lignina (Strack, 1997); (3). participação em reações catalizadas por peroxidases que levam a formação de ligações cruzadas de glicoproteínas ricas em hidroxiprolina e ao fortalecimento da parede celular vegetal (Tenhaken et al., 1995) e (4). toxidez direta sobre patógenos (Mauch-Mani \& Métraux, 1998).

Partindo do princípio que existem moléculas elicitoras na parede celular de $S$. cerevisiae, capazes de induzir respostas de defesa em soja e pepino, é possível que estes compostos induzam resistência nestas plantas. Dessa maneira, este trabalho teve como objetivo isolar e caracterizar frações de uma suspensão autoclavada de células de $S$. cerevisiae, capazes de elicitar a síntese de fitoalexinas em soja, e interferir nas interações soja $x$ Microsphaera diffusa e pepino $x$ Colletotrichum lagenarium. 


\section{REVISÃO DE LITERATURA}

\subsection{Aspectos gerais da indução de resistência}

Com toda a competitividade e globalização que vêm ocorrendo hoje, é cada vez mais necessário adequar os meios de produção de modo a obter produtos e serviços que atendam aos desejos do consumidor, que sejam "ecologicamente corretos" e que tragam retorno financeiro ao produtor.

No mercado de commodities, como é o de produtos agrícolas, é imperiosa a busca de formas de produção que aumentem a produtividade sem aumentar excessivamente o custo, permitindo um bom retorno ao produtor. Uma das causas de perda de produção no campo é a ocorrência de doenças. Para seu controle milhares de dólares são gastos anualmente com produtos químicos, no Brasil, principalmente fungicidas.

O controle químico de doenças vêm se mostrando eficaz. No entanto, alguns problemas associados a ele vem sendo constantemente questionados pelo meio científico e pela sociedade.

O desenvolvimento de populações de patógenos resistentes a produtos químicos, como aconteceu com o benomyl na década de 70 (Staub, 1991), além de tornar mais difícil o controle da doença, leva a grandes perdas tanto por parte da indústria de pesticidas como por parte do agricultor. Outro ponto questionável ligado ao uso de produtos químicos é o desbalanço ecológico que esses podem provocar, visto atingirem não só o patógeno mas também outros organismos. O próprio aplicador de pesticidas, no Brasil, recebe freqüentemente doses elevadas de produtos químicos que acabam por depauperar sua saúde. Também tem sua saúde comprometida aquele consumidor que, inadvertidamente, se alimenta de vegetais ou grãos com resíduos de agroquímicos. Hoje, a população mundial, principalmente a européia, está 
mais atenta a esses problemas, e vem exigindo produtos que, além de terem qualidade, não tenham agredido o meio ambiente durante sua produção nem tampouco contenham resíduos tóxicos.

Além das opções alternativas clássicas de controle de doenças, como o controle biológico e a pré-imunização (Kimati \& Bergamin Filho, 1995), a indução de resistência (resistência sistêmica adquirida: RSA) vem se firmando como uma opção ecológicamente correta e economicamente viável.

O fenômeno da RSA já é conhecido desde o começo do século passado, tendo, como marco inicial, o trabalho desenvolvido por Chester, em 1933 (Moraes, 1998). A partir desse trabalho, muitos outros foram realizados na busca de produtos de defesa, em plantas, com função semelhante a de anticorpos (Lucas, 1999). Todos fracassaram. Hoje é sabido que os produtos de defesa produzidos pelas plantas não têm nenhuma semelhança com anticorpos.

A partir da década de 60 , os trabalhos se tornaram mais consistentes. Em 1961, Ross demonstrou que plantas de fumo submetidas a uma infecção prévia com o vírus do mosaico do fumo ("tobacco mosaic virus" - TMV) se tornavam resistentes a uma nova infecção do vírus. Um ano antes, Cruickshank e Mandryk obtiveram plantas de fumo resistentes ao mofo azul pela inoculação das hastes das plantas com Peronospora tabacina (Lucas, 1999).

A partir daí as pesquisas na área de indução de resistência proliferaram, sendo que hoje há inúmeros trabalhos sendo constantemente publicados em periódicos da área agrícola e biológica.

O potencial para uso de indutores de resistência no controle de doenças não chamou a atenção apenas da comunidade acadêmica, mas também da área comercial. Atualmente, existem cinco indutores de resistência no mercado mundial: o Oryzemate ${ }^{\circledR}$, o Bion ${ }^{\circledR}$, o Messenger ${ }^{\circledR}$, o Oxycom ${ }^{\mathrm{TM}}$ e o Elexa ${ }^{\circledR}$, sendo que os quatro últimos receberam registro entre 1996 e 2001 . O Oryzemate ${ }^{\circledR}$ (probenazole) é um produto para proteção do arroz contra a brusone que já conta com mais de 20 anos de mercado no Japão e sem que haja um único relato de surgimento de resistência em populações de Pyricularia grisea. Segundo Uehara ${ }^{1}$, há 3 anos o produto se firmou

1 UEHARA, F. (Syngenta Crop Protection Japan Agricultural Research Station Technical Dept.). Comunicação pessoal, 1999. 
como líder de mercado, para o segmento de arroz no Japão. Além do arroz esse produto é usado em algumas culturas hortícolas, mostrando-se efetivo, não só para o controle de fungos e bactérias, mas também para o controle de viroses (Koganezawa et al., 1998). O Bion ${ }^{\circledR}$ (acibenzolar S-metil, ASM) foi lançado em 1996 na Alemanha. Hoje, já tem registro em diversos países, inclusive no Brasil. A comercialização do Bion ${ }^{\circledR}$ é feita em formulações em que o ASM é o único produto ativo ou ainda em formulações onde há um fungicida conjugado. No caso de formulações em que o ASM é o único princípio ativo, o produto é recomendado em parceria com fungicidas. Isso provavelmente se deve ao fato de que o uso de um indutor de resistência, junto com um fungicida, apresenta efeitos sinérgicos no controle das doenças-alvo (Hammerschmidt, 1999a; Molina et al., 1998). O ASM é um análogo do ácido salicílico (AS) e age na cascata de sinais, um dos eventos que leva à RSA (Hammerschmidt et al., 2001; Métraux, 2001; Oostendorp et al.; 2001). $O$ ingrediente ativo do Messenger ${ }^{\oplus}$ é uma proteína, produzida por um gene $h r p$, da bactéria fitopatogênica Erwinia amylovora. $\bigcirc$ Elexa $^{\circledR}$, além de ingredientes inertes, contém um carboidrato, a quitosana, extraído do exoesqueleto de crustáceos. Tanto a proteína hrp do Messenger $^{\circledR}$ como a quitosana do Elexa ${ }^{\circledR}$ agem ligando-se a receptores existentes na membrana celular de plantas, mimetizando o fenômeno de reconhecimento que ocorre em uma interação incompatível entre planta e patógeno (Eden Bioscience, 2001; SafeScience, 2001). Já o Oxycom ${ }^{\mathrm{TM}}$ é formado pela combinação de dois compostos, o primeiro é uma mistura de nutrientes e o segundo uma mistura de ácido peracético, ácido acético e $\mathrm{H}_{2} \mathrm{O}_{2}$. $\mathrm{O}$ produto é capaz de aumentar a atividade de enzimas importantes ligadas a RSA, como a fenilalanina amônia-liase (FAL), chalcona sintase e peroxidases (PO) e proteger plantas contra nematóides e fungos (Kim et al., 2001).

Além dos indutores comerciais citados anteriormente, diversos agentes vêm sendo estudados como possíveis elicitores de respostas de defesa ou indutores de resistência. Esses agentes podem incluir um produto químico, como, entre outros, o ácido salicílico (Siegrist et al., 1994; Spletzer \& Enyedi, 1999), o ácido $\beta$-amino butírico (BABA) (Jakab et al., 2001), etefon (Jacobs et al, 1999), e o metil salicilato (Shulaev et al, 1997), o estresse de natureza biótica (Chamnongpol et al., 1998) ou abiótica (Moran \& Cipollini, 1999), um patógeno avirulento (Ogallo \& McClure, 1996), parte de um patógeno, como uma glicoproteína (Costet et al., 1999) ou um carboidrato estrutural (Andreu et al. 1998; Hahn \& Albersheim, 1978), um organismo não patogênico, como 
as bactérias promotoras de crescimento (Mauch-Mani \& Métraux, 1998; Ramammoorthy et al. 2001; Zehnder et al., 2001) ou a levedura $S$. cerevisiae (Pascholati, 1998). Além do uso em campo, alguns indutores de resistência, como a luz UV, têm também potencial para uso em pós-colheita (Stevens et al., 1999).

Em uma relação incompatível planta-patógeno, a combinação de barreiras químicas e estruturais, pré e pós-formadas, impede o sucesso do patógeno. Para a formação das chamadas barreiras pós-formadas, a planta deve: (1). reconhecer o patógeno, (2). emitir um sinal primário (ou mensageiro), que desencadeia uma série de outros sinais, e (3). ativar genes ligados a defesa ou aumentar a atividade de enzimas importantes para reações de defesa (Honeé, 1999; van Loon \& van Strien, 1999). Havendo a ativação desses genes, ocorre a produção sincronizada, localizada e/ou sistêmica, de produtos que vão deter ou atrasar, a colonização pelo agente patogênico. Em uma relação compatível planta-patógeno, alguma das etapas do processo falha, seja pela falta de produção de compostos de defesa, pela desativação dos compostos de defesa ou pela ausência de um fator essencial ao patógeno no hospedeiro (Moraes, 1998).

A princípio, todas as plantas são capazes de expressar genes de resistência, desde que recebam o estímulo adequado (Tuzun, 2001). A indução de resistência busca transformar uma relação compatível planta-patógeno em uma relação incompatível. Para tanto é necessário interferir em uma das três etapas citadas no parágrafo acima e ativar, corretamente, o sistema de defesa. Havendo a ativação do sistema de defesa ocorre uma série de alterações bioquímicas, muitas das quais ainda não são completamente compreendidas. Os primeiros eventos desencadeados são: alteração no fluxo de íons através da membrana citoplasmática $\left(\mathrm{Ca}^{2+}, \mathrm{K}^{+}\right.$e $\left.\mathrm{H}^{+}\right)$, alteração da concentração do cAMP, constantes fosforilações e desfosforilações de proteínas reguladoras e a explosão oxidativa (Leite et al., 1997; Low \& Schroeder, 1997). Como conseqüência destas primeiras alterações, o pH celular e a atividade de certas enzimas são modificados, o que resulta na ativação imediata de determinados genes de defesa e na manutenção de outros genes em estado de alerta (estado de competência ou 'primming'). Quando um patógeno entra em contato com a planta, os genes em estado de alerta são ativados, levando àsíntese de novos compostos e ao aumento da atividade de enzimas importantes para a defesa (como a fenilalaninaamonialiase - FAL e peroxidases) (Conrath et al., 2001). A produção de compostos 
tóxicos e a formação de barreiras estruturais, de modo coerente, faz com que a infecção seja retardada.

A indução de resistência em plantas contra patógenos muitas vezes é comparada com a vacinação em vertebrados. No entanto, ao contrário da vacinação, 0 fenômeno de RAS é inespecífico. Na RSA, inúmeros compostos, desde enzimas hidrolíticas, fenóis de ação fungitóxica a até proteínas capazes de impedir a replicação de RNA viral podem ser produzidas como resposta a um mesmo estímulo (Fauth et al., 1996, Kästner et al., 1998; Murphy et al., 2001; Siegrist et al., 1994). Portanto, o uso de um mesmo indutor é capaz de conferir proteção a diferentes tipos de patógenos, como fungos, oomicetos, bactérias, virus e até nematóides (Godard et al.,1999; Görlach et al.,1996; Ishii et al., 1999; Oostendorp, 2001). Porém, cabe resaltar que muitas vezes a inespecificidade não é tão abrangente. O ASM, por exemplo, confere proteção a pepino contra Colletotricum lagenarium (Ishii et al., 1999), mas falha na proteção da mesma planta contra Sphaerotheca fuliginea (Wurms et al., 1999).

A orquestração da resposta de defesa, para ser efetiva, deve ser extremamente precisa. A simples presença de um ou mais compostos ligados à defesa, como fitoalexinas ou proteínas relacionadas a patogênese (proteínas-RP) não implica, necessariamente, no estabelecimento de um patossistema incompatível. A síntese de fitoalexinas, a reação de hipersensibilidade, a formação de papilas, a geração de espécies ativas de oxigênio (EAOs) e a produção de enzimas hidrolíticas ocorrem tanto em relações compatíveis, como em relações incompatíveis (Kogel \& Hückelhoven, 1999; Kombrink \& Schmelzer, 2001; Lo et al., 1999; Wurms et al., 1999). O que vai diferir uma relação incompatível da compatível não é a presença ou ausência de compostos relacionados àdefesa, mas sim a sua eficácia.

Como fica claro pela leitura dos parágrafos anteriores, o estabelecimento da RSA é um fenômeno multicomponente em que cada componente deve estar no local, quantidade e tempo precisos. Devido à complexidade das respostas de defesa é necessário que o tratamento indutor seja realizado algum tempo antes da chegada do patógeno. Esse tempo varia conforme o patossistema e o indutor. Com um intervalo de apenas $3 \mathrm{~h}$ entre o tratamento com ASM e a inoculação, plantas de pepino já manifestam resistência contra C. lagenarium (Ishii et al., 1999). No entanto, é necessário cerca de 1 semana de intervalo quando o tratamento indutor no pepino é realizado com o próprio patógeno (Dean \& Kuc, 1986). O período de proteção 
conferido pelo indutor também depende do patossistema e do indutor, podendo este ser tão longo quanto o período de cultivo (Görlach et al., 1996).

O clássico triângulo (ou tetraedro) da doença nos diz que não apenas a análise do patossistema é suficiente para inferir sobre o resultado de uma interação planta-patógeno (Agrios, 1997). O ambiente desempenha papel fundamental no metabolismo da planta, do patógeno e também nos eventos que ocorrem na interação dos dois organismos (Ellingboe, 2001). Sendo asssim, é de se esperar que a resistência induzida também seja modulada pelas condições ambientais.

O nitrogênio é um elemento capaz de interferir nas relações plantapatógeno, aumentanto ou diminuindo a severidade da doença conforme seus níveis no solo, na planta e a sua relação com o cálcio (Richard-Molard et al., 1999; Schober \& Vermeulen, 1999). Em parte, os efeitos do nitrogênio podem ser atribuídos à alteração na expressão de determinados genes dos patógenos. Genes hrp de bactérias são expressos em meio deficiente em nitrogênio, mas não o são em meio rico (Snoeijers et al., 2000). Condições de estresse, como o vento, levam ao aumento da atividade de peroxidases em pepino e estabelecimento de RSA (Moran \& Cipollini, 1999). O estresse abiótico também altera a expressão de quitinase em plantas tratadas com ácido $\beta$-aminobutírico (Jakab et al., 2001). A falta ou excesso de água e salinidade interferem no metabolismo das plantas, tornando-as, muitas vezes, mais suscetíveis a fitopatógenos e a insetos (Bostock, 1999; Farrar et al., 2000). A temperatura é um outro fator ambiental capaz de interferir na expressão de doenças: não é possível estabelecer RSA em Arabidopsis e fumo no inverno e, em temperaturas acima de $32^{\circ} \mathrm{C}$ não é verificada indução de resistência em fumo contra TMV (Cameron, 2000; Sticher et al., 1997). O aumento de suscetibilidade é reflexo da alteração do metabolismo das plantas e/ou do patógeno, ou seja, por algum motivo não há expressão plena das respostas de defesa. Daí surge a pergunta: será que uma condição de estresse pode anular o efeito de um indutor de resistência?

Em condições de campo as plantas estão sujeitas não só a estresse, mas também à ação de diversos organismos nocivos, sejam eles fitopatógenos ou insetos. O controle de doenças pelo uso de indutores de resistência como o ASM é dependente (pelo menos em parte) de uma via de sinalização que envolve o ácido salicílico (AS). Em vários casos esta via é capaz de inibir uma outra via, dependente de jasmonatos (JA) (Bostock, 1999; Heil, 2001). A produção de inibidores de proteinases, 
muito importante para a resistência de plantas a insetos mastigadores, é dependente de JA (Sticher et al., 1997). Assim sendo, nos casos em que a via dependente de AS inibe a dependente de JA, é esperado um aumento de suscetibilidade a insetos mastigadores em plantas tratadas com um indutor de RSA.

Muitos aspectos da sinalização, transdução de sinais e expressão de genes relacionados a defesa, que ocorrem durante o estabelecimento de RSA, ainda não são conhecidos. As pesquisas avançam rápido. Novos elicitores, comerciais ou não, assim como plantas transgênicas que expressam constitutivamente genes relacionados a defesa vêm sendo desenvolvidos. A possibilidade de proteger uma planta sem agredir o meio ambiente abre um novo leque no controle de doenças. No entanto, a influência do ambiente e a possibilidade de indução de suscetibilidade a pragas ou a outras doenças que não a alvo devem ser avaliados no desenvolvimento de um novo produto, ou de estratégias de controle.

\subsection{Reconhecimento}

Para que haja uma resposta de defesa por parte da planta é necessário, primeiramente, que a planta reconheça o patógeno. Este reconhecimento normalmente se dá por meio da ligação de um elicitor a um receptor presente na membrana plasmática. A partir desta ligação ocorre a sinalização e a síntese de compostos de defesa (Figura 1).

Há alguns anos atrás, os elicitores eram definidos como sendo moléculas capazes de induzir a síntese de fitoalexinas em tecido vegetal. Atualmente, elicitor é definido como uma molécula capaz de induzir qualquer resposta de defesa (Graham, 1995). Assim_sendo, os termos elicitor e indutor podem ser usados como sinônimos.

O reconhecimento do patógeno ou de um elicitor por uma planta é essencial para a maioria dos casos de resistência inespecífica e para muitos casos de indução de resistência. No entanto, é bom salientar que em determinadas relações incompatíveis e na indução de resistência com certos indutores (como o ASM) não há envolvimento da etapa de reconhecimento no estabelecimento de respostas de defesa (Heath, 2001a). 

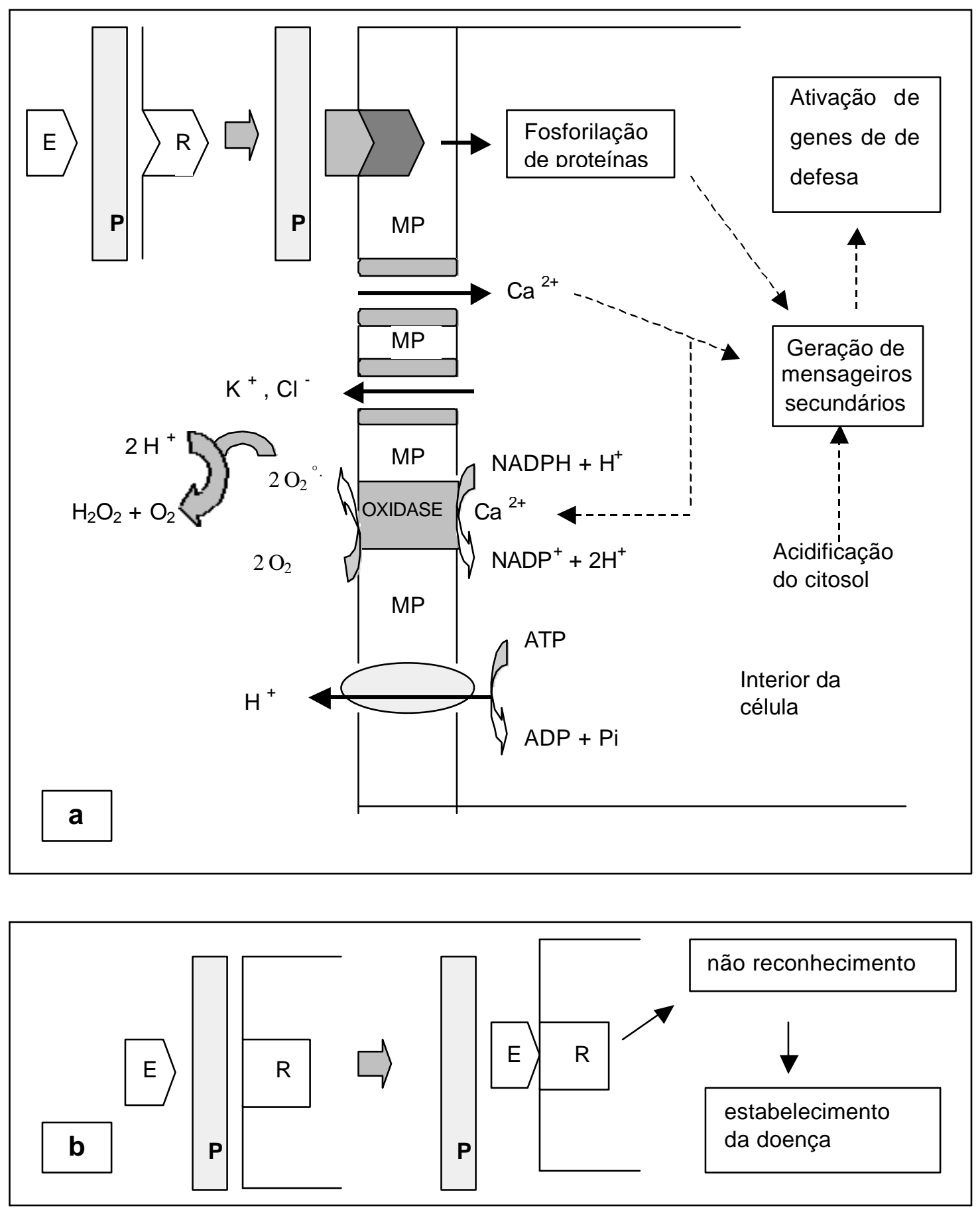

Figura 1 - Esquema simplificado (a). das etapas de reconhecimento, sinalização e respostas de defesa em uma relação incompatível; (b). não reconhecimento - relação incompatível (adaptado de Leite et al., 1997; Ricci, 1997). $E$ = elicitor; $R=$ receptor; $P=$ parede celular; $M P=$ membrana plasmática. 
A etapa de reconhecimento envolve a ligação de um elicitor a um receptor presente na célula vegetal . Normalmente, o receptor é de natureza protéica e pode estar localizado tanto na membrana plasmática como no interior da célula vegetal. No caso da maioria dos fungos e nematóides, os receptores estão localizados na membrana plamática. Já para o caso de vírus e muitas bactérias, os receptores estão no interior da célula, seja no citoplasma ou até no núcleo (Hutcheson, 1998). Não existem muitos dados a respeito do modo de como é realizada a ligação entre o elicitor e o receptor, mas, se houver semelhança com o reconhecimento em mamíferos, a ligação receptor-elicitor pode ser multivalente. Neste caso, um elicitor pode se ligar a mais de um receptor ou a mais de um sítio de um mesmo receptor (Bertozzi \& Kiessling, 2001).

A maior parte dos elicitores é de origem biótica, derivados de um microrganismo ou de uma planta. No entanto, estresses abióticos como, por exemplo, ferimentos, podem liberar moléculas que vão agir como sinalizadores ou mesmo elicitores, sendo portanto, considerados como elicitores abióticos (Fauth et al., 1996).

Elicitores bióticos podem ser isolados tanto a partir de tecido vegetal como de fungos, bactérias ou vírus (Andreu et al., 1998; Hutcheson, 1998; Slováková et al., 2000; Wei et al, 1992). Na maior parte dos casos, estes elicitores purificados são proteínas, carboidratos ou glicoproteínas (Hahn, 1996; Ricci, 1997) que têm a capacidade de transformar uma relação compatível numa relação incompatível (Schaffrath et al., 1995).

O grau de especificidade dos elicitores varia conforme sua fonte. Elicitores produzidos por genes avr são os mais específicos, seguindo a teoria gene-agene. Exemplo disto é o caso da proteína AVR9 produzida por Cladosporium fulvum e capaz de induzir diversas respostas de defesa apenas em variedades de tomate que contêm o gene de rersistência Cf9. Raças virulentas não produzem elicitores ou os elicitores produzidos não são reconhecidos devido àausência do gene de resistência no hospedeiro (van den Ackerveken \& de Wit, 1995). O elicitor AVR9 pode se ligar à membrana celular de outras plantas que não o tomate. No entanto, nestes casos, não ocorre nenhuma resposta de defesa (Kooman-Gersmann et al.,1996).

Bem menos específicos que os elicitores AVR encontramos as elicitinas. As elicitinas são proteínas extracelulares produzidas por diferentes espécies 
fitopatogênicas de Phytophthora capazes de induzir (ou elicitar) respostas de defesa em grande gama de plantas (Ricci, 1997).

Ainda dentro dos elicitores protéicos encontramos as harpinas. As harpinas são pequenas proteínas produzidas por bactérias apenas quando há expressão de um gene hrp e são capazes de induzir respostas de defesa, como a reação de hipersensibilidade em não hospedeiros do patógeno (Hutcheson, 1998; Wei et al., 1992). Uma harpina de E. amylovora vem sendo usada comercialmente como um indutor de resistência com o nome de Messenger ${ }^{\circledR}$ (Eden Bioscience, 2001).

Parte dos elicitores protéicos, como os referidos acima, não exibem atividade enzimática e, em muitos casos, a exposição ao calor não altera sua atividade como elicitor (Davis et al, 1998; Wei et al., 1992; Wulff \& Pascholati, 1999). Isto é um forte indicativo de que a seqüência de aminoácidos é mais importante do que a estrutura terciária da molécula. Por outro lado, alguns elicitores protéicos dependem não só da estrutura terciária, mas também da estrutura quaternária da molécula para serem ativos (Hutcheson, 1998). Cervone et al. (1989) isolaram de feijão um elicitor protéico capaz de inibir a ação de poligalacturonase fúngica. A poligalacturonase degrada substâncias pécticas da parede celular vegetal, facilitando a colonização pelo patógeno. O inibidor da poligalacturonase retarda a ação da enzima, gerando apenas moléculas com alto grau de polimerização que agem como elicitores, induzindo respostas de defesa na planta. Moléculas pequenas geradas na ausência do inibidor não têm ação elicitora. Os inibidores de enzimas se encaixam nas enzimas, dependendo, portanto, de sua conformação espacial para apresentarem atividade.

Fato interessante a respeito dos elicitores é que muitos deles não necessitam de toda a sua estrutura para serem ativos. Algumas glicoproteínas necessitam apenas da porção protéica ou da porção glicosilada para induzirem respostas de defesa (Guzzo, 1989; Schweizer et al, 2000; Wulff \& Pascholati, 1999). Em outros casos, a alteração da molécula elicitora pela retirada de ramificações ou de outros grupamentos pode manter intacta, aumentar ou diminuir sua atividade elicitora (Basse et al., 1992; Ricci et al., 1993). O elicitor glicoprotéico isolado a partir de micélio de Pyricularia grisea necessita apenas da porção glicosilada para ser ativo. No entanto, o tratamento com tripsina (uma enzima proteolítica) aumenta o poder elicitor do composto (Schaffrath et al., 1995), o que ilustra a complexidade das relações elicitorplanta. 
Em casos mais drásticos, a alteração da composição de um elicitor pode até mesmo transformá-lo em supressor. A clivagem enzimática de uma invertase de levedura é capaz de produzir uma mistura heterogênea de glicopeptídeos capazes de induzir respostas de defesa em células de tomate. No entanto, a ação da endo- $\beta-N$ acetilglucosaminidase sobre os elicitores leva àliberação de oligossacarídeos capazes de suprimir a ação elicitora (Basse et al., 1992). Outro fato que chama a atenção a respeito da estrutura de elicitores, principalmente carboidratos, é a importância do grau de polimerização para a atividade elicitora. Freqüentemente, apenas oligômeros dentro de uma faixa estreita de grau de polimerização são ativos (Svalheim \& Robertsen, 1993; Séjalon-Délmas et al., 1997; Slováková et al., 2000).

Diversos carboidratos com atividade elicitora não específica já foram isolados da parede celular fúngica (Schaffrath et al., 1995; Schweizer et al, 2000; Hahn \& Albersheim, 1978), muitos dos quais são compostos comuns, como glucanas, mananas e oligomeros formados por $\mathrm{N}$-acetilglucosamina e que estão presentes constitutivamente na parede celular dos fungos. A presença destes compostos em diversos fungos e seu poder elicitor leva a crer na possibilidade de que a ação de enzimas vegetais, como a quitinase e a $\beta-1,3$ glucanase, possa liberar da parede do patógeno estes compostos, os quais ativam o sistema de defesa da planta (Hammerschmidt, 1999a).

Se por um lado glucanas extraídas da parede celular de patógenos podem ter ação elicitora, por outro lado esta mesma classe de carboidratos pode agir como supressora, como é o caso de glucanas do micélio de Phythophthora infestans. Glucanas isoladas a partir de uma raça pouco virulenta do fungo não alteram as respostas de defesa induzidas por ácido eicosapentaenóico. Já as glucanas isoladas a partir de raças mais virulentas suprimem estas respostas de defesa (Andreu et al., 1998).

A interação entre fungo e planta é um processo muito ativo e durante este processo há constante síntese de glucanas, mananas e outros elicitores presentes na parede celular fúngica. Por exemplo, foi isolado da parede micelial de Phytophthora parasitica var. nicotianae um elicitor glicoprotéico cuja cinética de síntese é diferente em relações compatíveis e em relações incompatíveis. Em relações incompatíveis, a sua síntese ocorre a partir de 48 h após a inoculação, enquanto que, em relações 
compatíveis a síntese só se dá em estádios mais avançados da infecção (SéjalonDélmas et al., 1997). O atraso na síntese do elicitor permite ao fungo se estabelecer e causar a doença, já que a planta não o reconhece.

Elicitores podem ser extraídos de microrganismos ou plantas por diversos métodos, como a hidrólise e a solubilização em água usando ou não calor (Guzzo, 1989; Slováková et al., 2000; Schweizer et d, 2000). De modo geral, a purificação segue etapas que incluem precipitação etanólica, cetônica ou com sulfato de amônio e uma sequência de cromatografias (Hahn \& Albersheim, 1978; Koch et al., 1998; Schaffrath et al., 1995; Wulff \& Pascholati, 1999). A obtenção de um elicitor puro pode ter várias finalidades, entre as quais o estudo de sinalização e a busca de um produto que possa ser usado como indutor de resistência comercial, como foi o caso da harpina de $E$. amylovora. Um dos fatos que torna importante o uso de elicitores purificados é a possível presença de supressores em extratos brutos, capazes de interferir com a ação do elicitor (Shiraishi et al., 1997; Wulff \& Pascholati, 1999).

\subsection{Sinalização}

Algum tempo depois de haver o reconhecimento, a planta passa a manifestar as respostas de defesa. No entanto, para que ocorram estas respostas, é necessário haver a geração de sinais primários, que agiriam em cascata e de sinais translocáveis que causariam a ativação de genes relacionados à defesa, tanto local como sistemicamente (Figura 1). A natureza do sinalizador primário não é conhecida. É pouco provável que este sinalizador seja uma molécula orgânica, pois para sua síntese

ou liberação, seria necessário um outro sinal. É possível que o sinalizador primário seja um sinal elétrico que poderia, por exemplo, agir liberando uma molécula sinalizadora compartimentalizada (Kuc, 1995).

Antes da geração de um sinal primário e após a ligação do elicitor com o receptor, um dos eventos que provavelmente ocorre é a alteração da conformação do receptor, o que leva à exposição de um sítio de ligação para a proteína G. A ligação da proteína $\mathrm{G}$ ao receptor aumenta a afinidade da primeira pelo GTP, o que leva àsua ativação e causa a dissociação de suas sub-unidades. Isto traz, como consequência, a 
ativação de proteínas, como fosfolipases, canais de íons, adenil ciclase e receptores de quinases (Leite et al., 1997; Low \& Schroeder, 1997).

Algumas fosfolipases estão envolvidas, entre outras coisas, na ativação de quinases de proteínas moduladas por cálcio. A fosforilação de proteínas citoplasmáticas por quinases pode levar ao estímulo de uma oxidase de mebrana envolvida na geração do íon superóxido, que, por sua vez, inicia a explosão oxidativa (Tenhaken et al., 1995). A explosão oxidativa é um evento importante no desenvolvimento da reação de hipersensibilidade e de outras respostas de defesa (Chamnongpol et al., 1998; Costet et al., 1999; Greenberg, 1996; Kogel \& Hückelhoven, 1999).

Embora a sinalização não seja completamente compreendida, ao que parece as etapas envolvidas não seguem uma linha reta que termina na ativação de genes de defesa. É provavel que existam bifurcações na cascata sinalizadora e que estas bifurcações levem a diferentes respostas de defesa. $O$ trabalho conduzido por Koch et al. (1998) ilustra este aspecto. Estes autores utilizaram inibidores da fosfolipase $\mathrm{C}$ em cultura de células de cenoura elicitadas com uma proteína fúngica. Os inibidores da enzima bloquearam a via dos fenilpropanóides sem afetar a reação de hipersensibilidade. Paralamente a isto, foi realizado tratamento de cultura de células, não elicitadas, com ativadores da proteína G. O último tratamento teve, como conseqüência, o estímulo da reação de hipersensibilidade sem que a via dos fenilpropanóides fosse afetada.

Os eventos de sinalização descritos nos parágrafos anteriores levam à produção de mensageiros secundários (EAOs, $\mathrm{Ca}^{2+}$, quinases de proteínas, jasmonatos, ácido salicílico, entre outros), o que ocasiona a transcrição de genes de defesa e o conseqüente estabelecimento da resposta de defesa (Leite et al, 1997).

Mensageiros como o ácido salicílico (AS) e os jasmonatos (JA) são de importância fundamental para a sinalização, sendo que cada um destes atua em uma via sinalizadora diferente (Bostock, 1999; Hammerschmidt, 1999a; Mauchi-Mani \& Métraux, 1998). Embora as vias dependentes de JA e AS sejam as mais discutidas, existem indícios da existência de outras vias, que podem até ser independentes de AS e de JA (Mauchi-Mani, citado por Oostendorp et al., 2001; van Loon \& van Strien, 1999). Acredita-se que haja uma intercomunicação entre as duas vias e, pelo menos em Arabidopsis, é sabido que as duas vias convergem pela dependência do gene npr1 
(Métraux, 2001; van Loon \& van Strien, 1999, van Loon et al., 2001). As duas rotas podem ser tanto excludentes como se manifestar concomitantemente (Bostock et al, 2001; Knoester et al., 1999).

Quando ocorre a indução de resistência pela via dependente de AS, uma das primeiras alterações manifestadas é o acúmulo do próprio AS nos tecidos vegetais (Costet et al, 1999; Repka et al., 2001). O fato ocorre devido ao aumento da atividade de enzimas da via dos fenilpropanóides, como a FAL, através da qual o AS é sintetizado (Métraux, 2001; Moraes, 1998; Sticher \& Métraux, 2000). Embora seja sabido que o AS não é o sinal móvel para a RSA (Costet et al., 1999; Moraes, 1998), diversos trabalhos mostram a importância do acúmulo do AS na ativação de respostas de defesa (Costet et al, 1999; Shulaev et al., 1997; Fauth et al, 1996).

O aumento da concentração de AS nos tecidos vegetais leva a aumento da resistência não só a fúngos e bacterias, mas também a vírus. No entanto, ao que parece, a cascata sinalizadora dependente de AS tem uma bifurcação. Um dos braços levaria àativação de genes que expressam proteínas como a RP1 e confeririam resistência a fungos, enquanto o outro braço levaria à ativação de uma oxidase mitocondrial alternativa, capaz de controlar os níveis de EAOs e que mediaria a resistência a vírus (Murphy et al., 2001).

Na maior parte dos trabalhos que demonstraram a importância do AS no estabelecimento da RSA, foram usadas plantas transgênicas para a produção de salicilato hidroxilase (plantas NahG) (Moraes, 1998; Sticher et al., 1997). A enzima impede o acúmulo de AS pela transformação deste em catecol. Considerando que o AS seja produzido na via dos fenilpropanóides e que, em plantas NahG, o AS seja transformado em catecol, é lógico pensar que as reações bioquímicas possam ser desviadas para produzir mais AS e que a produção de outros compostos seja prejudicada. Com esta linha de raciocínio, Cameron (2000) alerta para a possibilidade da incapacidade de plantas NahG em estabelecerem RSA não estar ligada diretamente ao AS, mas sim ao mal funcionamento da via dos fenilpropanóides, provocado pela retirada do AS e pela falta de outros compostos relacionados a defesa produzidos nesta mesma via.

$\mathrm{Na}$ via de sinalização dependente de JA não há a necessidade de acúmulo de AS, já que plantas NahG podem estabelecer resistência induzida mediada por JA (RSI) (van Loon et al., 2001). Trabalhos mostram que a aplicação de JA ou metil 
jasmonatos (MeJA) leva ao estabelecimento de RSI e que isto depende não só do JA ou do MeJA, mas também da resposta da planta ao etileno. Plantas que têm a síntese de etileno comprometida podem expressar RSA, mas não a RSI (Knoester et al., 1999; Kozlowski et al., 1999).

É comum encontrar revisões de literatura sobre indução de resistência que associam a RSA com a síntese de proteínas-RP e com o acúmulo de AS e a RSI com a síntese de defensinas, de tioninas e de inibidores de proteinase (Hammerschmidt, 1999a; Mauchi-Mani \& Métraux, 1998; Sticher et al., 1997). Ao que parece, há uma tendência em dividir as respostas de defesa induzidas pela RSA daquelas induzidas pela RSI. No entanto, resultados de pesquisas mostram que tanto o tratamento com um indutor de RSI, como as PGPR (rizobactérias promotoras de crescimento vegetal), como o tratamento com indutores de RSA podem levar ao mesmo tipo de respostas, como aumento de atividade da FAL, de peroxidases, da polifenoloxidase, da quitinase e da síntese de fenóis tóxicos (Chen et al., 2000; Kozlowski et al., 1999; Ongena et al., 2000; Ramamoorthy et al., 2001).

Hoje ainda existem muitas perguntas sobre os mecanismos de sinalização que levam ao estado de resistência induzida. A dependência de moléculas sinalizadoras (SA, JA ou outras) varia de caso para caso, conforme a combinação planta, indutor e patógeno e, tanto uma via como a outra, pode levar à resistência contra fungos, bactérias e vírus.

Antes de concluir o tópico sinalização, é importante salientar que a presença do sistema de sinalização intacto é importante não só para o estabelecimento de resistência induzida, mas também para a ação de fungicidas. O bloqueio de respostas de defesa em plantas de Arabidopsis interfere no controle químico de Peronospora tabacina. Por outro lado, o uso de um fungicida em conjunto com o ASM têm efeito sinérgico no controle de doenças (Molina et al., 1998).

\subsection{Respostas de defesa}

A etapa seguinte à sinalização é a manifestação de respostas de defesa. Normalmente estas respostas são divididas em barreiras estruturais e em 
barreiras químicas e podem ser resultado da ativação de genes de defesa ou do aumento da atividade de determinadas enzimas (Pascholati \& Leite, 1995).

A primeira barreira que um fungo encontra na planta é a cutícula. As cutinases produzidas por patógenos degradam a cutina, facilitando a penetração. A cutina presente na cutícula tem composição bastante complexa e, aparentemente, a indução de resistência é capaz de alterar sua composição, tornando-a mais resistente àdegradação enzimática (Huang \& Kuc, 1995).

Vencendo a cutícula, o fungo encontra a parede celular vegetal, que, assim como a cutícula, pode ser penetrada tanto por ação mecânica como por ação enzimática. No caso particular de pepino a fortificação da parede celular vegetal, obtida por tratamento com indutores de resistência, é responsável pelo fracasso de um grande número de tentativas de penetração de fungos. Em hipocótilos de pepino tratados com o ácido 2,6-dicloroisonicotínico (DCIA), a redução na penetração chega a ser de quase 100 \% em relação a hipocótilos não tratados (Fauth et al, 1996).

Estudos citológicos e histológicos demonstram que as alterações ocorridas em plantas com resistência induzida podem variar. Stein et al. (1993) verificaram que a indução de resistência em pepino através de inoculação controlada com Colletotrichum lagenarium não causa alterações citológicas qualitativas, mas sim, quantitativas. Já o uso de Milsana ${ }^{\circledR}$, também em pepino, provoca alterações qualitativas como formação de papilas, aposições de parede e acúmulo de compostos fenólicos, assim como modificações de estruturas do patógeno não observadas em patógenos presentes em tecidos não tratados com o indutor (Wurms et al., 1999). A mesma gama de respostas foi verificada em plantas de tomate tratadas com glucanas, quitina e laminarina e em plantas de ervilha, tratadas com um fungo endofítico. $O$ interessante nestes casos é que o patógeno, ou o fungo endofítico, penetram na planta tratada. No entanto, o desenvolvimento do fungo fica restrito æ̀s células da epiderme e suas estruturas sofrem alterações drásticas, inviabilizando a infecção (Benhamou \& Garand, 2001; Benhamou \& Lafontaine, 1995).

Fungos inoculados em plantas tratadas com ativadores de resistência apresentam germinação normal dos esporos com a emissão do tubo germinativo, formação de apressório e da hifa de penetração. No entanto, a penetração não ocorre normalmente. Muitas hifas de penetração são aprisionadas por papilas ou têm seu desenvolvimento retardado por aposições de parede, em ambos os casos impregnadas 
por compostos fenólicos. Outro fator estrutural que contribui para o insucesso da infecção é a fortificação da parede celular por meio de ligações cruzadas de glicoproteínas ricas em hidroxiprolina ou pelo aumento da lignificação (Agrios, 1997; Wurms et al., 1999).

Além das barreiras estruturais, diversas barreiras químicas também são formadas quando ocorre a indução de resistência. A indução de resistência leva à ativação de uma série de genes, conhecidos como genes-RSA. Esses genes codificam proteínas que têm atividades diversas e agem, em conjunto, para restringir a invasão do patógeno. Entre essas proteínas estão aquelas relacionadas a patogênese (proteínas-RP) e enzimas do metabolismo secundário vegetal.

As proteínas-RP são um grupo de enzimas sintetizadas em resposta à infecção ou a outras situações de estresse. Atualmente, essas proteínas estão agrupadas em 14 famílias, sendo que algumas têm atividade conhecida e outras não (van Loon \& van Strien, 1999).

Entre as proteínas-RP mais pesquisadas estão as quitinases e as $\beta$ 1,3 glucanases. Essas duas enzimas têm atividade hidrolítica, quebrando polímeros estruturais presentes na parede dos patógenos (Andreu et al., 1998; Lorito et al., 1993; Walton, 1997). A modificação genética de plantas para expressão constitutiva dessas proteínas faz com que a resistência contra infecções seja aumentada (Coventry \& Dubery, 2001; Evans \& Greenland, 1998; Honée, 1999; Lorito et al., 1998). Além disso, a atividade dessas enzimas é aumentada quando plantas são tratadas com elicitores de respostas de defesa ou indutores de resistência (Kästner et al., 1998; Görlach et al., 1996; Jacobs et al., 1999; Slováková et al., 2000; Schweizer et al., 2000). O incremento na atividade dessas enzimas e a restrição de patógenos, tanto em plantas modificadas geneticamente como em plantas tratadas com elicitores, leva a crer que as proteínasRP desempenham papel importante na contenção de infecções.

As respostas de defesa comentadas acima são apenas alguns dos mecanismos de proteção utilizados pelas plantas, sendo difícil avaliar o quanto cada uma contribui para o estado de resistência induzido. Uma das primeiras respostas de defesa manifestadas em relações incompatíveis é a explosão oxidativa que desempenha papel importante no estabelecimento da reação de hipersensibilidade (HR). A HR por sua vez é freqüentemente associada com a resistência induzida, sendo que, sem HR, não há resistência sistêmica induzida (Costet et al., 1999). 
Entre as reações bioquímicas de defesa freqüentemente verificadas em plantas de pepino tratadas com elicitores de respostas de defesa ou indutores de resistência temos: ocorrência de explosão oxidativa (Svalheim \& Robertsen, 1993), aumento na atividade da peroxidases e de enzimas hidrolíticas (Dalisay \& Kuc, 1995a,1995b; Moran \& Cipollini, 1999; Slóváková et al., 2000) e acúmulo de fitoalexinas fenólicas (Daayf et al., 1995, Daayf et al. 1997; Fawe et al., 1998). O aumento da lignificação (Stein et al., 1993), a explosão oxidativa, a HR, as peroxidases e os fenóis (incluindo fitoalexinas) estão bastante relacionados e serão discutidos, a seguir, em tópicos separados.

\subsubsection{Explosão oxidativa e reação de hipersensibilidade}

As espécies ativas (ou reativas) de oxigênio (EAOs) são um importante mecanismo de defesa das plantas e são geradas em relações compatíveis (de modo transiente) e incompatíveis (de modo duradouro) planta-patógeno, no local da tentativa de penetração, e durante o estabelecimento da RSA, na chamada explosão oxidativa. As EAOs são relacionadas principalmente com o enrijecimento da parede celular, devido ao aumento da lignificação e à formação de ligações cruzadas por glicoproteínas ricas em hidroxiprolina. No entanto, também têm papel importante na regulação de genes de defesa (incluindo aqui as enzimas antioxidantes), no estabelecimento da reação de hipersensibilidade, na peroxidação de lipídios e pela sua ação antimicrobiana direta (Chamnongpol et al., 1998; Greenberg, 1996; Low \& Schroeder, 1997; Ricci, 1997; Tenhaken, 1995)

Nos segundos ou minutos que se seguem ao reconhecimento ou a indução de resistência, é observado aumento na concentração de espécies ativas de oxigênio. As EAOs mais importantes biologicamente são os radicais livres superóxido e oxidrila, e o $\mathrm{H}_{2} \mathrm{O}_{2}$ (Leite et al., 1997). O ânion superóxido é gerado pela reação: NADPH

$+\mathrm{O}_{2} \rightarrow \mathrm{NADP}^{+}+\mathrm{H}^{+}+\mathrm{O}_{2}^{-}$, mediada por uma oxidase de membrana e logo depois convertido em $\mathrm{H}_{2} \mathrm{O}_{2}$ pela ação da enzima superóxido dismutase (Leite et al., 1997; Tenhaken et al., 1995). $\mathrm{O} \mathrm{H}_{2} \mathrm{O}_{2}$, por sua vez, dá origem ao $\mathrm{OH}^{\circ}$. As EAOs são altamente reativas e tóxicas (tanto a microrganismos quanto à célula vegetal), sendo 
rapidamente retiradas do meio pelas enzimas antioxidantes, como a glutationa-Stransferase e a glutationa peroxidase (Kombrink \& Schmelzer, 2001; Tenhaken et al., 1995 ).

A explosão oxidativa é regulada pela fosforilação e desfosforilação de proteínas reguladoras, é estimulada pelo AS, e ocorre em duas fases (Becker et al., 2000; Fauth et al., 1996; Repka et al., 2001; Siegrist et al, 1994; Tenhaken et al., 1995). A primeira fase da explosão oxidativa ocorre em segundos ou minutos após o contato com o elicitor, dura cerca de 30 min e é induzida em relações incompatíveis, compatíveis ou por elicitores purificados. A segunda fase ocorre de 1 a $3 \mathrm{~h}$ após a elicitação e, na maior parte dos casos, só ocorre em relações incompatíveis. A explosão oxidativa só é eficiente na restrição do patógeno quando ocorre em duas fases. Um bom exemplo é o gene de resistência Pto de tomate, que codifica uma quinase de proteína. $\mathrm{Na}$ ausência deste gene, plantas de tomate não apresentam a segunda fase da explosão oxidativa, não manifestam HR e são suscetíveis ao patógeno Pseudomonas syringae pv. tomato (Low \& Shroeder, 1997).

$\mathrm{O}$ padrão de produção de $\mathrm{H}_{2} \mathrm{O}_{2}$ durante a explosão oxidativa é, aparentemente, função do estímulo inicial. O tratamento de hipocótilos de pepino com oligogalacturonídios leva a um pico de produção de $\mathrm{H}_{2} \mathrm{O}_{2}$ após 8-10 h de incubação. $\mathrm{O}$ mesmo tratamento quando realizado com oligo- $\beta-$ glucanas de Phytophthora megasperma f. sp. glycinea atinge um pico após $6 \mathrm{~h}$ de incubação, sendo a concentração máxima atingida apenas $10-15 \%$ daquela atingida pelo tratamento com oligogalacturonídios (Svalheim \& Robertsen, 1993). Os autores do trabalho atribuem a diferença no padrão de produção do peróxido à possibilidade de diferentes elicitores ativarem diferentes rotas de sinalização ou de biossíntese da molécula.

Os eventos que levam ao estabelecimento de respostas de defesa ocorrem de modo cronológico e sincronizado. É perfeitamente plausível supor que, ocorrendo a explosão oxidativa, o primeiro efeito das EAOs seja a toxidez direta sobre o patógeno. Caso esse efeito não seja capaz de conter a invasão, poderá retardá-la e permitir a formação de outras barreiras, como o enrijecimento da parede celular que ocorre algum tempo após o início da explosão oxidativa (Svalheim \& Robertsen, 1993). A explosão oxidativa e o fortalecimento da parede celular contribuem para frear 0 avanço do patógeno. O patógeno que conseguir sobrepujar estas barreiras poderá se 
ver cercado por uma camada de células mortas, o que é conhecido como reação de hipersensíbilidade.

A HR é um tipo de morte celular programada que ocorre, por exemplo, em resposta à tentativa de penetração de um patógeno avirulento. A HR pode ser caracterizada por diversas alterações citológicas, entre as quais: movimentação do núcleo em direção ao patógeno; fragmentação de DNA; condensação do núcleo e citoplasma; degradação do núcleo; granulação do citoplasma; ativação da troca de íons $\mathrm{K}^{+} / \mathrm{H}^{+}$através da membrana e colapso da célula (Agrios, 1997; Greenberg, 1996; Koch et al, 1998). A morte das células que cercam o patógeno teoricamente mataria o invasor por inanição. No entanto, não há nenhuma prova definitiva de que a HR restrinja o desenvolvimento do patógeno e, no caso particular de viroses, evidências mostram que a HR não é suficiente para conter o avanço do vírus (Kombrink \& Schmelzer, 2001; Murphy et al., 2001).

Embora a HR seja considerada como uma das respostas de defesa mais importantes da célula vegetal, outros mecanismos de defesa, como a síntese de proteínas-RP e de outras proteínas do metabolismo secundário, podem ocorrer sem que ocorra HR (Costet et al., 1999; Schweizer et al., 2000). Costet et al. (1999) verificaram que tecido vegetal infiltrado com um elicitor em dose que não provoca HR apresenta resistência adquirida contra patógeno. No entanto, a $5 \mathrm{~mm}$ do local onde ocorreu a infiltração o tecido não apresenta resistência, levendo a crer que a HR é necessária para a geração de um sinalizador e para o estabelecimento da RSA.

É comum associar a HR com a geração de EAOs e, embora se saiba que as EAOs não sejam suficientes para ativar a HR, acredita-se que esses possam agir em conjunto com outros fatores ativando a HR. Em cevada com RSA ativada ocorre o acúmulo de $\mathrm{O}_{2}{ }^{-}$em cloroplastos de células do mesófilo, mas não nas células da epiderme que sofreram HR. O fato confirma a hipótese de que as EAOs isoladamente não são capazes de induzir a HR (Kogel \& Hückelhoven, 1999).

Sumarizando o que já foi apresentado, a HR é importante para o estabelecimento da RSA (talvez até indispensável) e as EAOs estão ligadas a manifestação da $\mathrm{HR}$. A geração de $\mathrm{H}_{2} \mathrm{O}_{2}$, entre outras EAOs, faz necessária a ação de enzimas antioxidantes, como as peroxidases, o que além, de limitar os danos causados pelas EAOs, também pode gerar outras respostas de defesa. 


\subsubsection{Peroxidases}

As peroxidases (PO) são glicoproteínas capazes de catalisar um grande número de reações. Entre as reações que catalizam estão a produção de $\mathrm{H}_{2} \mathrm{O}_{2}$, a formação de lignina (Griesebach, 1981; Strack, 1997); incorporação de glicoproteínas ricas em hidroxiprolina à parede celular (Tenhaken et al., 1995) e destruição peroxidativa do ácido indolilacético e de outros reguladores de crescimento (Barz \& Köster, 1981).

As diversas reações catalisadas por peroxidases ocorrem em diferentes locais da célula, sendo esperado, portanto, que a localização das enzimas seja função da reação que catalisam. A formação de lignina e a geração de $\mathrm{H}_{2} \mathrm{O}_{2}$ ocorrem próximo a parede celular. As peroxidases envolvidas nestas reações ocorrem comumente ligadas a parede celular (Strack, 1997).

A geração de $\mathrm{H}_{2} \mathrm{O}_{2}$, assim como de outras EAOs, ocorre no metabolismo normal das células vegetais e pode ser potencializada frente a estresse biótico ou abiótico. As peroxidases, junto com outras enzimas, como a superóxido dismutase e a catalase, atuam sobre as EAOs de modo a livrar a célula de seu efeito deletério (Tuzun, 2001). Assim sendo, é comum verificar aumento na atividade destas enzimas não só quando as plantas são injuriadas por um patógeno, mas também quando as plantas são expostas a outros tipos de estresse (Jagtap \& Bhargava, 1995; Peixoto et al., 1999).

Para os fitopatologistas o interesse maior no estudo das peroxidases envolve o papel que elas desempenham na restrição de um patógeno. $O$ aumento da atividade de peroxidases é observado quando ocorre uma infecção (Kofalvi \& Nassuth, 1995; Ray \& Hammerschmidt, 1998). Esse aumento de atividade é maior, normalmente, em cultivares resistentes (Gowda et al., 1989) ou em plantas tratadas com indutores de resistência do que em relações compatíveis (Chen et al., 2000; Moran \& Cipollini, 1999; Oliveira, 1994; Roncato \& Pascholati, 1998; Slováková et al., 2000). No entanto, essas enzimas não têm uma relação direta com o estabelecimento da RSA. Plantas de tomate transformadas para expressão de uma peroxidase de pepino tiveram um grande aumento na atividade das enzimas. No entanto, não foi verificado aumento de resistência dessas plantas a patógenos (Ray et al., 1998). Dalisay \& Kuc (1995a, 1995b) demostraram que as peroxidases não tem relação direta 
com a RSA em pepino e, portanto, não podem ser usadas como um marcadores de resistência.

Embora as peroxidases não possam ser utilizadas como marcadores de resistência, a alteração na sua atividade ou no perfil eletroforético de suas isoformas é um indício de metabolismo alterado. A alteração de metabolismo em organismos vivos raramente é pontual, já que as diversas rotas metabólicas interagem. Uma das funções das peroxidases é a formação da lignina pela polimerização de fenóis (Figura 2). Assim sendo, é esperado que alterações na atividade de peroxidases envolvam também alteração na atividade de outras enzimas presentes na mesma rota metabólica. Devido a estes fatos, as peroxidases são usadas em estudos de indução de resistência, não como um marcador, mas sim como uma das muitas respostas de defesa manifestadas pelas plantas.

Uma das mais importantes respostas de defesa, pelo menos em pepino, expressa durante a RSA, é a lignificação (Nicholson \& Hammerschmidt, 1992). O processo da lignificação é iniciado pela migração de vesículas armazenadoras de fenóis no sentido da parede celular. Ao chegarem à parede, ocorre a descompartimentalização dos fenóis, muitos dos quais ocorrem na forma glicosilada. No momento da descompartimentalização, através de reação enzimática, a porção glicosídica é separada da porção fenólica. Os fenóis livres podem sofrer oxidação, ligação à parede celular ou serem polimerizados. $\mathrm{A}$ ação do $\mathrm{H}_{2} \mathrm{O}_{2}$, catalizada por uma peroxidase, sobre os alcoóis 4-coumaril, coniferil e sinapil leva à geração de radicais livres e àformação de lignina. Paralelo a formação da lignina, alguns fenóis (ferulato, cafeato, sinapato) ligam-se àparede celular servindo como uma ponte de ligação entre a lignina e a parede celular (Grisebach, 1981; Strack, 1997).

A deposição de lignina e outros fenóis na parede celular e até em papilas torna essas estruturas mais resistentes à penetração fúngica. Oliveira (1994) mostrou que a formação de lignina em hipocótilos de Mimosa scabrella, induzida por fungo não patogênico, é precedida pelo aumento da atividade de peroxidases, que ocorre entre 30 e $48 \mathrm{~h}$ após a inoculação. Entre 12 e 48 h após a inoculação ocorre a germinação do fungo, formação de apressório e início da penetração, fenômenos que, por si só, são suficientes para desencadear respostas de defesa. $O$ estudo com fungos endofíticos e com um mutante de $C$. lagenarium deficiente em melanina, mostrou que $o$ 


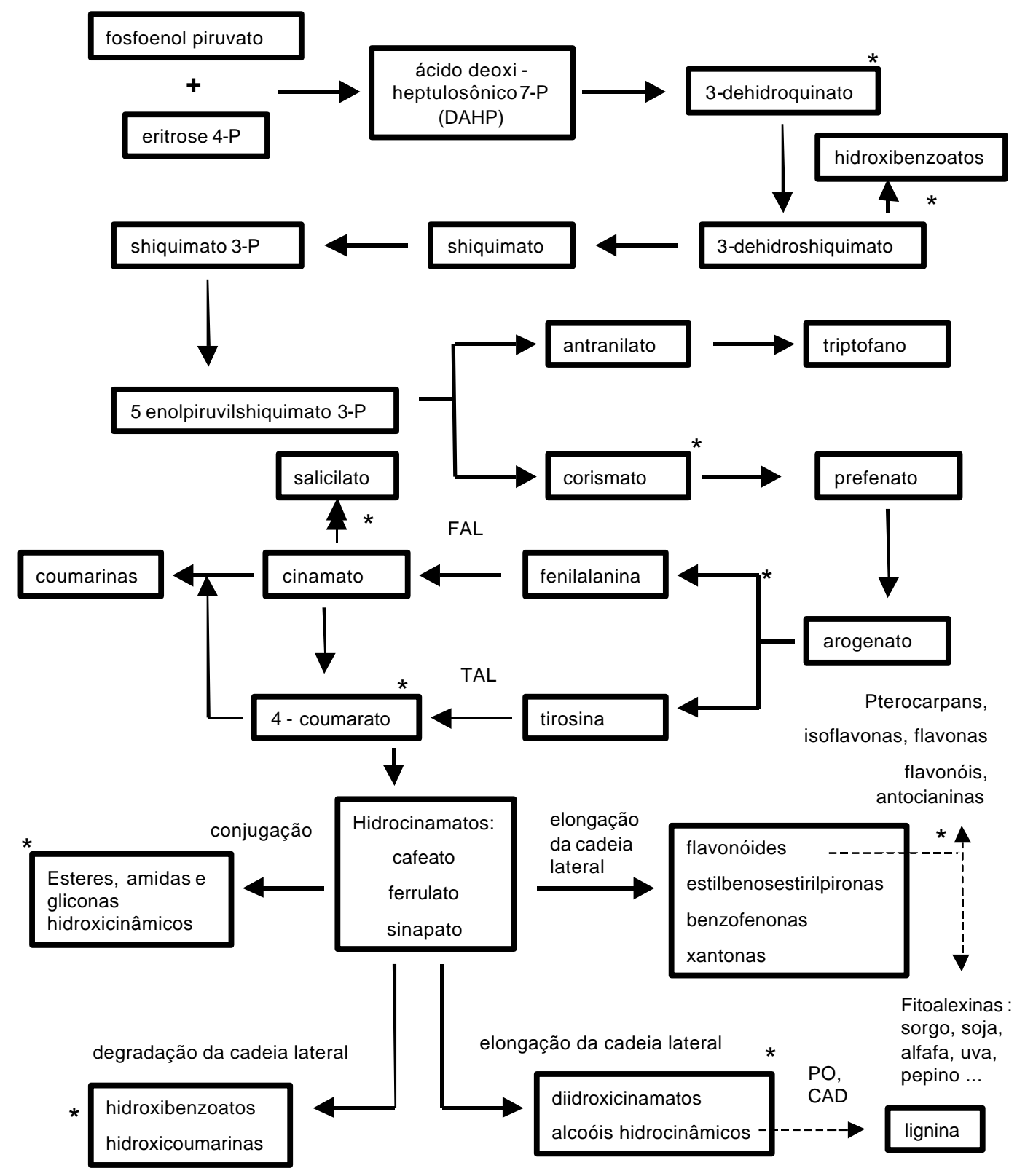

Figura 2 - Esquema da via do shiquimato (adaptado de Strack, 1997). * Saída de intermadiário ou produtos para formação de outros compostos ou alimentação de outras vias. $F A L=$ fenilalanina amônia-liase; $\mathrm{TAL}=$ tirosina amônia-liase; $\mathrm{PO}=$ peroxidase; $\mathrm{CAD}=$ álcool cinamil desidroaenase. 
simples crescimento desses fungos sobre a superfície da planta já é suficiente para a manifestação de respostas de defesa (Behnamou \& Garand, 2001; Kästner et al., 1998). Para serem efetivas, as respostas de defesa devem seguir uma determinada ordem cronológica (Pascholati \& Leite, 1995). Dessas respostas, a formação de papilas, aposições em parede e lignificação devem ocorrer antes ou, concomitantemente, àpenetração. Como peroxidases são envolvidas na formação de lignina, é esperado também que o aumento na sua atividade ocorra em até 48 h após a inoculação.

\subsubsection{Fenóis e fitoalexinas}

Quimicamente falando, fenóis são compostos formados por um anel benzeno ao qual é ligado pelo menos um grupamento hidroxila. Os fenóis produzidos pelas plantas apresentam grande diversidade estrutural e funcional (Hagerman \& Butler, 1991). Nem todos os fenóis têm função conhecida, sendo que alguns deles parecem ser simples intermediários do metabolismo normal das plantas (Beckman, 2000). Entre as funções conhecidas de alguns fenóis está a defesa da planta contra a invasão de patógenos (Nicholson \& Hammerschmidt, 1992).

Os compostos fenólicos são sintetizados normalmente pelas plantas através da via do acetato/malonato, do acetato/mevalonato e do shiquimato (Figura 2). Embora as rotas de produção de fenóis sejam classificada como metabolismo secundário, sua importância é fundamental para o metabolismo vegetal. Além dos fenóis, os aminoácidos aromáticos fenilalanina, tirosina e triptofano também são produzidos pela via do shiquimato. Ao que parece, a produção de aminoácidos para a síntese protéica e dos fenilpropanóides, embora envolva a mesma rota biossintética, ocorre em locais diferentes da célula. A síntese de aminoácidos para a produção de proteínas ocorre principalmente em cloroplastos e a síntese de aminoácidos para a produção dos fenilpropanóides ocorre no citosol (Strack, 1997).

Os fenóis são produzidos em células especializadas distribuídas pelos tecidos, ao acaso ou em locais estratégicos. As enzimas dessa síntese são associadas ao retículo endoplasmático, o que permite que, logo após a produção, esses compostos sejam armazenados em vesículas, na sua forma original ou glicosilada. A 
compartimentalização é fundamental para o funcionamento das células, pois os fenóis são tóxicos e devem ser mantidos na sua forma reduzida. A descompartimentalização de fenóis pode levar àsua rápida oxidação, pela ação de peroxidases, em resposta a uma infecção. Fenóis que se mantem livres no citoplasma podem ter ação tóxica tanto sobre patógenos como sobre a própria célula vegetal e contribuir para a reação de hipersensibilidade (Hrazdina, 1994; Isaac, 1992).

Além de causar a liberação de compostos altamente tóxicos, a descompartimentalização e a oxidação de fenóis são capazes, também, de mediar a conversão de triptofano para ácido indolilacético (AIA). Com isso, o balanço AIA/citocinina fica alterado e, pode ter como consequência, o crescimento lateral de células e a formação de tiloses (Beckman, 2000). As tiloses agem como barreira estrutural, bloqueando vasos do xilema e impedindo a movimentação de alguns patógenos (Agrios, 1997; Pascholati \& Leite, 1995).

Como já citado anteriormente, os fenóis vêm sendo considerados como compostos que fazem parte do arsenal de defesa das plantas, podendo contribuir para o isolamento de um patógeno, ainda no sítio de infecção. Ao que parece, o acúmulo de fenóis ocorre seguindo duas etapas. A primeira etapa, que leva ao acúmulo dos fenóis ao redor do sítio de infecção, é rápida e não envolve síntese protéica. A segunda etapa envolve a síntese de compostos de ação mais específica, como, por exemplo, as fitoalexinas, em células que cercam o sítio de infecção (Nicholson \& Hammerschmidt, 1992).

Muitos dos fenóis produzidos pelas plantas têm ação fungitóxica direta. A catequina, produzida por folhas de morango, em resposta à inoculação com um isolado não patogênico de Alternaria alternata, é capaz de impedir a formação normal da hifa de penetração do patógeno virulento e inibir a manifestação dos sintomas de pinta-preta (Yamamoto et al., 2000). Já epicatequina, presente em frutos imaturos de abacate, é capaz de inibir a ação de uma liase do pectato produzida por Colletotrichum gloeosporioides. A inibição da enzima está, provavelmente, ligada a resistência dos frutos imaturos àantracnose (Wattad et al., 1994).

O acúmulo de fenóis em tecidos vegetais depende do patossistema, do nível de resistência do hospedeiro e, no caso de resistência induzida, do indutor. Segundo Stermer (1995) o estabelecimento da RSA não é acompanhada por alteração na concentração de fenóis, exceto por uma queda drástica após a infecção. No 
entanto, Siegrist et al. (1994) verificaram que hipocótilos de pepino tratados com um inditor de resistência e inoculados com $C$. lagenarium apresentam aumento na concentração de fenóis ligados à parede celular, informação aparentemente contraditória àanterior.

Estudos citológicos freqüentemente localizam compostos fenólicos em tecidos resistentes que foram desafiados por um patógeno (Benhamou \& Garand, 2001; Benhamou \& Lafontaine, 1995; Wurms et al., 1999). Tal acúmulo ocorre não só na parede, mas também em papilas e aposições, tornando-as mais resistentes à degradação fúngica.

Se, em alguns casos, a participação de fenóis na resposta de defesa de plantas contra patógenos é questionável, em outros casos é incontestável. Certos casos de resistência em milho são bons exemplos da importância dos fenóis. A resistência a Cochliobolus heterostrophus em plantas de milho portadoras do gene rhm envolve, quase que exclusivamente, fenilpropanóides (Nicholson \& Hammerschmidt, 1992). Plantas de milho e sorgo resistentes a Peronosclerospora sorghi apresentam não só diferenças quantitativas, mas também qualitativas em seus conjuntos de fenóis (Anwar et al., 1995).

Enzimas como a álcool cinamil desidrogenase (CAD), a FAL e as peroxidases (Figura 2) desempenham papel importante na via dos fenilpropanóides e, por isso, são bastante estudadas. Em algumas plantas, a FAL ocorre como um conjunto de isoenzimas, em outras como uma única enzima. A atividade ou síntese das isoformas da FAL pode ser aumentada pelo tratamento com elitores e inibida por fenóis, sendo que a resposta varia de isoforma para isoforma (Jorrin \& Dixon, 1990). Fato interessante é que o tratamento com elicitor pode levar a uma forte indução da via dos fenilpropanóides, com aumento marcante da atividade da FAL, mesmo em células sofrendo morte celular (HR) (Koch et al., 1998).

O aumento da atividade da FAL é freqüentemente associado ao aumento da concentração de fenilpropanóides. Um exame rápido da Figura 2 faz acreditar que o aumento na atividade da FAL deve ter como conseqüência aumento também na atividade da CAD e da PO. O aumento na atividade da CAD em trigo infectado pelo vírus do mosaico da estria do trigo (WSMV - "wheat streak mosaic virus") é acompanhado pelo aumento na concentração de fenóis livres e ligados. No entanto, a atividade da FAL se mantém inalterada (Kofalvi \& Nassuth, 1995). Em 
tecidos de sorgo tratados com elicitores extraídos de Saccharomyces cerevisiae é observado aumento na síntese de fitoalexinas fenólicas (cuja produção é dependente da via dos fenilpropanóides) (Wulff \& Pascholati, 1999) e alterações de peroxidases (Roncato \& Pascholati, 1998). No entanto, o mesmo tipo de tratamento não leva a aumento na síntese da FAL (Kamida et al., 2000).

Se o aumento da atividade de uma enzima da via dos fenilpropanóides resultasse em aumento das demais enzimas, todo aumento de atividade poderia ter como resultado final um aumento na lignificação, o que não é verdade (Kofalvi \& Nassuth, 1995). Em todas as rotas metabólicas são produzidos intermediários que alimentam outras vias. No caso dos fenilpropanóides, o aumento da FAL leva a aumento da síntese de fenilalanina que, por sua vez, pode levar a aumento da concentração de coumarato. O coumarato pode tanto continuar na via dos fenilpropanóides e levar a incremento na síntese de lignina (associado a aumento na atividade da $\mathrm{PO}$ ), como pode ser desviado para a produção de hidroxibenzoatos, flavonóides ou outros fenóis (Figura 2).

A lignina é um polímero fenólico formado pela condensação, ao acaso, de alcoóis cinâmicos (Hagerman \& Butler, 1991). O início da formação da lignina ocorre pela ligação de hidroxicinamatos, através de esterificação, a sítios específicos de polissacarídeos da parede primária. Estes hidroxicinamatos servem como uma âncora para a lignina. A oxidação de alcoóis hidroxicinâmicos, mediada por peroxidases, leva àformação de radicais livres que rapidamente sofrem polimerização e se ligam uns aos outros, ao acaso, formando a lignina (Strack, 1997).

$\mathrm{O}$ aumento da lignificação torna a parede celular mais resistente à ação de patógenos e é considerada como componente fundamental da resistência induzida em cucurbitáceas (Nicholson \& Hammerschmidt, 1992). Como mencionado anteriormente, os alcoóis hidroxicinâmicos são polimerizados ao acaso para a formação da lignina e em tecidos com resistência induzida ocorre uma alteração qualitativa dos fenóis formados. Portanto, é de se esperar que não só a quantidade de lignina formada mas também a qualidade desta tenha papel importante nas reações de defesa.

Como pode ser observado nos parágrafos anteriores, os fenóis produzidos pelas plantas têm papel importante na defesa, pela formação de barreiras bioquímicas ou de barreiras estruturais. Existe um grande número de fenóis, de baixo 
peso molecular, produzidos em resposta àinfecção ou ao estresse, que fazem parte de um grupo de compostos, com atividade antimicrobiana, conhecidos como fitoalexinas. Embora a maior parte das fitoalexinas seja formada por compostos fenólicos, existem até fitoalexinas inorgânicas. As fitoalexinas são conhecidas desde a década de 40 . No entanto, ainda não foi estabelecido seu papel, definitivamente, como composto de defesa (Hammerschmidt, 1999b).

O estudo das fitoalexinas é um pouco mais complexo que o estudo de, por exemplo, proteínas-RP. As proteínas são sintetizadas tendo como base um molde, sendo, portanto, produtos diretos de um gene. Já as fitoalexinas são sintetizadas através de diversos passos metabólicos que envolvem uma série de enzimas. Sendo assim, abordagens que são usadas para o estudo de enzimas, como o uso de plantas transgênicas, não são facilmente aplicadas ao estudo de fitoalexinas (Hammerschmidt, 1999b; Heath, 2001b).

Estudos citológicos capazes de determinar o local, a quantidade e o momento da síntese de fitoalexinas são fundamentais para a definição do papel destes compostos na defesa. As fitoalexinas produzidas quando tecidos de sorgo são inoculados com um patógeno (luteolidinina, metoxiluteolidinina, éster do ácido caféicoarabinosil 50-apigeninidina e apigeninidina) são coloridas e se prestam bem para esse tipo de estudo. A síntese dessas fitoalexinas ocorre em inclusões citoplasmáticas próximas ao local da tentativa de penetração do fungo. Essas inclusões se movem em direção ao sítio de infecção e despejam seu conteúdo no citoplasma, interferindo com o desenvolvimento do patógeno (Snyder \& Nicholson, 1990). A síntese das fitoalexinas ocorre em ordem cronológica, tanto em relações compatíveis como em relações incompatíveis entre sorgo e C. sublineolum (Lo et al., 1999; Wharton \& Nicholson, 2000). Na relação incompatível, as quatro fitoalexinas são produzidas na fase de préinfecção (formação da vesícula de infecção). Já na relação compatível, a síntese de fitoalexinas ocorre somente no início da fase de infeç̧ão (formação das hifas primárias) e não há produção de luteolidinina nem de metoxiluteolidinina, que são as fitoalexinas de maior poder fungitóxico e as primeiras a serem sintetizadas (Lo et al., 1999; Wharton \& Nicholson, 2000). Assim sendo, não basta apenas que o sorgo sintetize fitoalexinas, mas sim que sintetize todas as fitoalexinas na quantidade, tempo e local adequados para que elas, junto com outros compostos defesa, ajam para restringir o desenvolvimento de um patógeno. 
Bagas de uva submetidas a tratamento com luz ultravioleta, são capazes de produzir duas fitoalexinas: o revasterol e o pterostilbeno. Do mesmo modo que o sorgo, as duas fitoalexinas diferem em fungitoxidez, momento e quantidade em que são sintetizadas (Sarig et al, 1997). No caso do sorgo e de uva, tanto cultivares resistentes como suscetíveis são capazes de acumular fitoalexinas. Já culturas de células de macieira resistente a Venturia inaequalis, tratadas com elicitor fúngico, apresentam a produção de seis compostos fenólicos que não são produzidos por cultivar suscetível. Um destes compostos é produzido na forma glicosilada e é mantido em alta concentração até $96 \mathrm{~h}$ após a elicitação. Esse composto foi identificado como malusfuran e classificado como uma fitoalexina (Hrazdina et al., 1997).

Em algumas culturas a infecção por Meloidogyne é capaz de levar a aumento na expressão de fusarioses, no caso de infecções mistas. O fato era, inicialmete, relacionado com a abertura de uma porta de entrada pelo nematóide para o fungo. Hoje é sabido que a predisposição à doença envolve fatores muito mais complexos que a simples facilitação da entrada do fungo. Estudos realizados com Meloidogyne sp. e Fusarium udum levam a crer que a fitoalexina cajanol tem papel importante nesta interação. A inoculação de uma cultivar de feijão-guandu resistente ao fungo com o nematóide leva à supressão da síntese da fitoalexina e à suscetibilidade a F. udum (Marley \& Hillocks, 1994).

O estabelecimento de RSA em pepino é normalmente ligado à atividade de $\beta$ 1-3 glucanases, quitinases e peroxidases e ao aumento da lignificação. Nos últimos anos, uma série de estudos envolvento a indução de resistência em pepino contra Sphaeroteca fuliginea detectou a síntese de conjugados fenólicos fitotóxicos. Entre esses fenóis, dois foram identificados como fitoalexinas: o éster metílico do ácido $\rho$-coumarico e a rhamnetina. $\mathrm{Na}$ indução de resistência de pepino contra S. fuliginea os fenóis, aparentemente, têm papel muito mais importante do que as enzimas hidrolíticas (Daayf et al., 1995; Daayf et al., 1997; Fawe et al., 1998; Wurms et al., 1999).

Sumarizando o que já foi apresentado sobre fenóis e fitoalexinas, temos que em algumas relações, como as descritas acima, os fenóis e as fitoalexinas têm papel fundamental. No entanto, em outras relações, o papel desses compostos ainda carece de estudos. 


\subsection{Saccharomyces cerevisiae e a indução de resistência}

A S. cerevisiae é um ascomiceto leveduriforme, ou seja o crescimento da colônia se dá por brotação das células, não existindo micélio (Agrios, 1997; Isaac, 1992). A levedura é amplamente distribuida na natureza, sendo comumente encontrada na superfície de frutos.

Um dos tipos de resistência expressa pelas plantas é a chamada resistência básica (ou não específica). Esse tipo de resistência confere proteção contra uma grande gama de patógenos potenciais, dos quais a espécie da planta é não hospedeira. A resistência básica consiste na presença de várias barreiras químicas ou estruturais, pré-existentes ou que podem ser induzidas por vários organismos. Essas barreiras têm a capacidade de impedir a penetração e colonização pelo microrganismo (Heath, 1995; Heath, 2001a).

Organismos não patogênicos, habitantes da superfície vegetal, têm a capacidade de crescer, se multiplicar e até de penetrar nas primeiras camadas de células de um órgão vegetal, sem causar doença (Behnamou \& Garand, 2001). A doença não ocorre porque a planta é capaz de reconhecer o organismo e gerar respostas de defesa.

Alguns estudos apontam para a possibilidade da levedura $S$. cerevisiae induzir mecanismos de defesa não específicos (Behnamou \& Lafontaine, 1995; Hahn \& Albersheim, 1978; Roncato \& Pascholati, 1998; Wulff \& Pascholati, 1999). É muito provável que a resistência induzida por S. cerevisiae esteja ligada à presença de determinados carboidratos e glicoproteínas presentes em sua parede celular (Hahn \& Albersheim, 1978; Wulff \& Pascholati, 1999)

A parede da levedura é formada basicamente por polissacarídeos e proteínas, com a seguinte distribuição aproximada, em peso: $50 \% \beta-1,3$-glucanas, $10 \% \beta-1,6$ - glucanas, $40 \%$ manoproteínas e $1-3 \%$ quitina (Lipke \& Ovalle, 1998). As manoproteínas são localizadas na superfície da parede celular e apresentam carga devido àpresença de fósforo (Cabib et al., 1982).

Noventa por cento da quitina está presente na cicatriz originada pela divisão celular. A quitina da levedura é um polímero de $\mathrm{N}$-acetilglucosamina (em ligação $\beta-1,4)$ que ocorre na sua forma $\alpha$, sendo de difícil extração. A extração química 
de glucanas pode ser feita por por tratamento com ácido, a quente, e com base. Já as mananas são facilmente extraídas por autoclavagem (Cabib et al., 1982).

As $\beta-1,6$ glucanas são responsáveis pela ligação das manoproteínas e da quitina às $\beta-1,3$ glucanas (Kollár et al., 1997). De um modo simplificado, a parede da levedura pode ser dividida conforme a Figura 3.

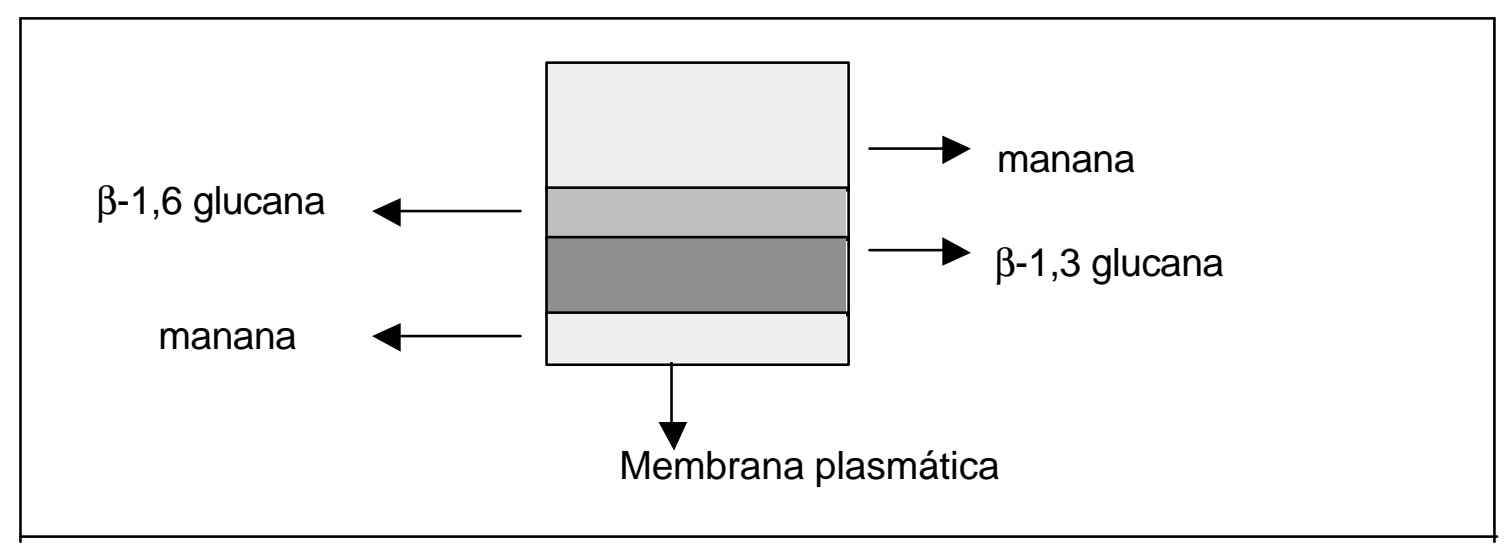

Figura 3 - Esquema da distribuição de polissacarídeos na parede celular de Saccharomyces cerevisiae (adaptado de Cabib et al., 1982).

As manoproteínas são formadas pela incorporação de manose em cadeia linear por ligações glicosídicas $\beta-1,6$ e em ramificações com ligações $\beta-1$,2. A ligação entre o polissacarídeo e a porção protéica se dá através da incorporação de duas moléculas de $\mathrm{N}$-acetilglucosamina, conforme a Figura 4.

A autoclavagem de células de $S$. cerevisiae leva a liberação de diversos polímeros e oligômeros com massa molecular, carga e conteúdo de açúcares e de proteínas bastante variavel. Wulff \& Pascholati (1999) extraíram desse modo uma glicoproteína carregada negativameente $(\mathrm{em} \mathrm{pH} 8)$, cuja porção protéica é importante para a indução da síntese de fitoalexinas em mesocótilos de sorgo.

Outros autores, usando a levedura, puderam induzir resistência em diversas plantas, conforme o Quadro 1. Os dados apresentados nesse quadro, junto com o que foi comentado anteriormente, levam a crer que existam na parede celular da levedura elicitores capazes de induzir resistência em plantas contra patógenos. 
(M-M-M-M-M $)_{\mathrm{n}}-\mathrm{M}-\mathrm{M}-\mathrm{M}-\mathrm{M}-\mathrm{M}-\mathrm{NAcGlc}$ - NAcGlc-Asn-PEPTÍDIO-Ser ou Thr

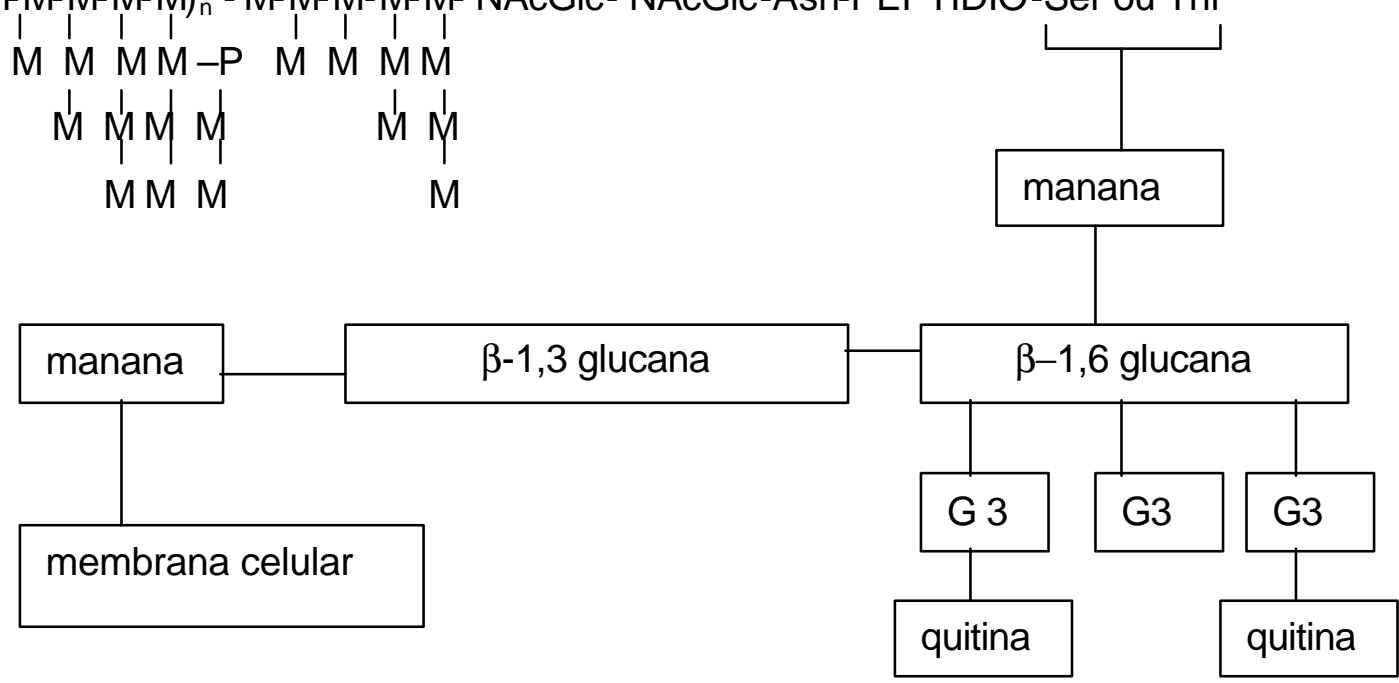

Figura 4 - Estrutura de uma manoproteína de Saccharomyces cerevisiae e suas ligações com outros polissacarídeos. $\mathrm{M}=$ manose; $\mathrm{P}=$ fósforo; $\mathrm{NAcGlc}=$ $\mathrm{N}$-acetilglucosamina; Asn = asparagina; Ser = serina; Thr = treonina; G3 = ramificações laterais de $\beta-1,3$ glucanas (adaptado de Cabib et al., 1982 e Kollár et al., 1997). 


\begin{tabular}{|c|c|c|}
\hline CULTURA & PATÓGENO & CONCLUSÖES \\
\hline & $\begin{array}{l}\text { C. graminicola } \\
\text { (in vitro) }\end{array}$ & $\begin{array}{l}\text { Inibição da germinação de conídios pelo extrato de } \\
\text { levedura e pelo filtrado do extrato. Redução do } \\
\text { crescimento micelial. }\end{array}$ \\
\hline & $\begin{array}{l}\text { E. turcicum } \\
\text { (in vitro) }\end{array}$ & $\begin{array}{l}\text { Inibição da germinação de conídios pela suspensão de } \\
\text { células da levedura e inibição parcial de germinação } \\
\text { de conídios pelo filtrado da suspensão. }\end{array}$ \\
\hline Milho & $\begin{array}{l}\text { C. graminicola } \\
\text { (in vivo - casa de } \\
\text { vegetação) }\end{array}$ & $\begin{array}{l}\text { Redução da germinação de conídios e de formação de } \\
\text { apressório. Redução da área foliar lesionada e de } \\
\text { número de lesões. Perda do poder de redução } 24 \mathrm{~h} \\
\text { após a aplicação da levedura. Autoclavagem leva à } \\
\text { perda total da capacidade inibitória. }\end{array}$ \\
\hline Milho & $\begin{array}{l}\text { E. turcicum } \\
\text { (in vivo - câmara } \\
\text { de crescimento) }\end{array}$ & $\begin{array}{l}\text { Redução da germinação de conídios e de penetração, } \\
\text { aumento na formação de apressórios. Redução no } \\
\text { tamanho das lesões e no número de lesões/planta. }\end{array}$ \\
\hline Sorgo & $\begin{array}{l}\text { C. graminicola } \\
\text { (in vivo - casa de } \\
\text { vegetação) } \\
\text { (in vivo - } \\
\text { campo) }\end{array}$ & $\begin{array}{l}\text { Plantas em casa de vegetação: Redução na } \\
\text { severidade da doença. Plantas em campo: Redução } \\
\text { no número de lesões e severidade da doença, quando } \\
\text { da aplicação da levedura antes ou após o patógeno. } \\
\text { Produção de grãos equivalente àdo sorgo tratado com } \\
\text { fungicida. }\end{array}$ \\
\hline Sorgo & $\begin{array}{l}\text { E. turcicum } \\
\text { (in vivo - campo) }\end{array}$ & $\begin{array}{l}\text { Atraso na manifestação dos sintomas, redução na } \\
\text { severidade da doença e produção de grãos } \\
\text { equivalente àdo sorgo tratado com fungicida. }\end{array}$ \\
\hline Eucalipto & $\begin{array}{l}\text { Botrytis cinerea } \\
\text { (in vivo - câmara } \\
\text { de crescimento) }\end{array}$ & Proteção de mudas. \\
\hline Maracujá & $\begin{array}{l}\text { Xanthomonas } \\
\text { campestris pv. } \\
\text { passiflora } \\
\text { (in vivo-casa } \\
\text { de vegetação) } \\
\end{array}$ & $\begin{array}{l}\text { Redução do número de lesões locais e infecção } \\
\text { sistêmica. Atraso na manifestação de sintomas. }\end{array}$ \\
\hline
\end{tabular}

Quadro 1 - Efeito de Saccharomyces cerevisiae sobre fitopatógenos na proteção de diversas plantas (adaptado de Pascholati, 1998). 


\section{MATERIAL E MÉTODOS}

\subsection{Extração e purificação dos elicitores}

A extração foi realizada pelo método descrito por Wulff \& Pascholati (1999). Uma suspensão de células de levedura (na proporção de $200 \mathrm{~g}$ do produto comercial - Fermento Biológico Fresco Fleishmann ${ }^{\circledR}$ - para volume final de $1 \mathrm{~L}$ de água destilada) foi autoclavada por $30 \mathrm{~min}$ a $121^{\circ} \mathrm{C}$ (1 atm). A suspensão resultante foi resfriada em banho de gelo e centrifugada a $4.500 \mathrm{~g}$ por $15 \mathrm{~min}$. Ao sobrenadante resultante (SSA) foi adicionado etanol lentamente, a $4^{\circ} \mathrm{C}$, na proporção de $1: 1(\mathrm{v} / \mathrm{v})$. Após 3 dias de repouso, a solução foi centrifugada a $20.000 \mathrm{~g}$ por $20 \mathrm{~min}$ e filtrada em membrana Millipore 0,45 $\mu \mathrm{m}$. O precipitado $(\mathrm{RC})$ foi ressuspenso em água e armazenado em congelador. O álcool foi retirado do sobrenadante (ECB) por evaporação a $48{ }^{\circ} \mathrm{C}$ sob pressão reduzida. O extrato aquoso resultante foi dialisado contra $12 \mathrm{~L}$ de água destilada, a $4^{\circ} \mathrm{C}$, por $44 \mathrm{~h}$ com cinco trocas de água. Após a diálise, o extrato bruto foi concentrado com polietilenoglicol (PEG) 20.000 ou por liofilização até volume final entre 40 e $50 \mathrm{~mL}$ (EC). A amostra concentrada foi armazenada em congelador. Em cada uma das etapas foi determinada a concentração de carboidratos redutores e de proteínas pelos métodos de Lever (1972) e Bradford (1976), respectivamente.

Cromatografia de troca-iônica - a coluna usada foi empacotada com a resina DEAE-Celulose (2,5 x $10 \mathrm{~cm})$, equilibrada com tampão Tris- $\mathrm{HCl} 0,01 \mathrm{M}(\mathrm{pH} 8,0)$. Amostras de $25 \mathrm{~mL}$ da preparação bruta (EC com concentração de carboidratos e de proteínas na faixa de $0,5-2,0 \mathrm{mg} / \mathrm{mL}$ ), foram aplicadas ao leito da coluna e eluídas, com o mesmo tampão de equilíbrio, a fluxo de $4 \mathrm{~mL} / \mathrm{min}$. Após a saída do material não adsorvido, o material adsorvido foi deslocado pelo uso de soluções de $\mathrm{NaCl}$, no 
tampão de equilíbrio, nas seguintes concentrações: $0,115 \mathrm{M}, 0,215 \mathrm{M}$ e 0,500 M. Foram coletadas amostras de $6 \mathrm{~mL}$. Para cada fração coletada, o conteúdo de carboidratos foi determinado pelo método de Lever (1972) e o de proteínas foi determinado através de leitura de absorbância a $280 \mathrm{~nm}$. As frações coletadas foram agrupadas conforme o conteúdo de carboidratos e de proteínas, formando seis novas frações, três delas contendo carboidratos e proteínas e três contendo apenas proteínas. Essas frações foram dialisadas contra $12 \mathrm{~L}$ de água destilada, a $4^{\circ} \mathrm{C}$ por $24 \mathrm{~h}$ (duas trocas de água). O material dialisado (membrana com corte para 12-14 $\mathrm{KDa}$ ) foi concentrado com o uso de PEG 20.000 ou por liofilização. O conteúdo de carboidratos e de proteínas foi determinado novamente para estas frações, usando os métodos já citados.

Cromatografia de afinidade - a coluna usada foi empacotada com a resina Concanavalina-A covalentemente ligada a Sepharose 4B (Con-A) $(13,6 \times 1,0$ $\mathrm{cm}$ ), equilibrada com tampão Tris- $\mathrm{HCl} 0,02 \mathrm{M}(\mathrm{pH} 7,4)$ contendo: 0,2 M NaCl; 0,001 M $\mathrm{CaCl}_{2} ; 0,001 \mathrm{M} \mathrm{MnCl}_{2}$ e 0,001 M MgCl (tampão Con-A) (Davis et al., 1998; McDougall, 1997; Guzzo, 1989; Hahn \& Albersheim, 1978; Pharmacia, 1991; Schaffrath et al., 1995). Amostras de 1,5 a $2,5 \mathrm{~mL}$ da fração DC1A (Figura 4) (com concentração de carboidratos na faixa de $0,5-2,5 \mathrm{mg} / \mathrm{mL}$ ), foram aplicadas ao leito da coluna e eluídas, com o mesmo tampão de equilíbrio, a fluxo de $0,5 \mathrm{~mL} / \mathrm{min}$. $O$ material não ligado foi eluído pelo uso de $50 \mathrm{~mL}$ do tampão Con-A. $O$ material ligado foi deslocado pelo uso de $50 \mathrm{~mL}$ de uma solução a $4 \%$ (p/v) de $\alpha$-D-manopiranosídio em tampão Con-A. Foram coletadas amostras de $4 \mathrm{~mL}$. Para cada fração coletada, o conteúdo de proteínas foi determinado através de leitura de absorbância a $280 \mathrm{~nm}$. Não foi possível determinar a concentração de carboidratos devido àpresença de $\alpha$-D-manopiranosídio na fração ligada. As frações coletadas foram agrupadas em duas novas frações: CA1 (não ligada) e CA2 (ligada). As duas novas frações foram dialisadas contra $7 \mathrm{~L}$ de água destilada, a $4^{\circ} \mathrm{C}$ por $24 \mathrm{~h}$ (duas trocas de água). O material dialisado foi concentrado por liofilização e a concentração de carboidratos e proteínas determinadas pelos métodos já citados.

Todo o material aplicado às colunas foi previamente filtrado em 
membrana Millipore 0,45 $\mu \mathrm{m}$ e deaerado, a vácuo, por 5 a 15 min. Após cada aplicação de amostra, as colunas foram regeneradas (Apêndice 1).

Em cada etapa da separação o poder elicitor das preparações (SSA, $E C, R C, D C 1 A, D C 1 B, D C 2, C A 1$ e CA2) foi confrontado em testes envolvendo cotilédones e/ou plantas de soja e de pepino. As frações que apresentaram o melhor desempenho seguiram para a etapa seguinte de separação.

As etapas gerais do processo de separação estão esquematizadas na Figura 5.

\subsection{Determinação do conteúdo de carboidratos e proteínas}

O conteúdo de carboidratos e proteínas foi determinado no sobrenadante da suspensão autoclavada de S. cerevisiae (SSA) e ao final de cada etapa de separação, segundo os métodos de Lever (1972) e Bradford (1976), tendo glucose e albumina de soro bovino (ASB), como padrões, respectivamente.

A curva padrão de proteínas foi determinada usando soluções de ASB nas concentrações de $0,3,6,9,12,15,18$ e $21 \mu \mathrm{g} / \mathrm{mL}$. A curva padrão de carboidratos foi determinada usando soluções de glucose nas concentrações de 0, 10, 20, 30, 40, 50, 60, e $70 \mu \mathrm{g} / \mathrm{mL}$ (Apêndice 2).

\subsection{Material vegetal}

Pepino (Cucumis sativus L.) - foram utilizadas sementes de pepino caipira, híbrido Guarani (AG 370), produzidas pela Seminis Vegetable Seeds do Brasil. As sementes utilizadas eram compostas por $90 \%$ de sementes de plantas fêmeas e $10 \%$ de sementes de polinizador e tratadas com Captan $\AA_{\text {. }}$.

Soja (Glycine $\max L$ ) - foi utilizado a cultivar IAC-8.2 cedida pelo Instituto Agronômico de Campinas. 


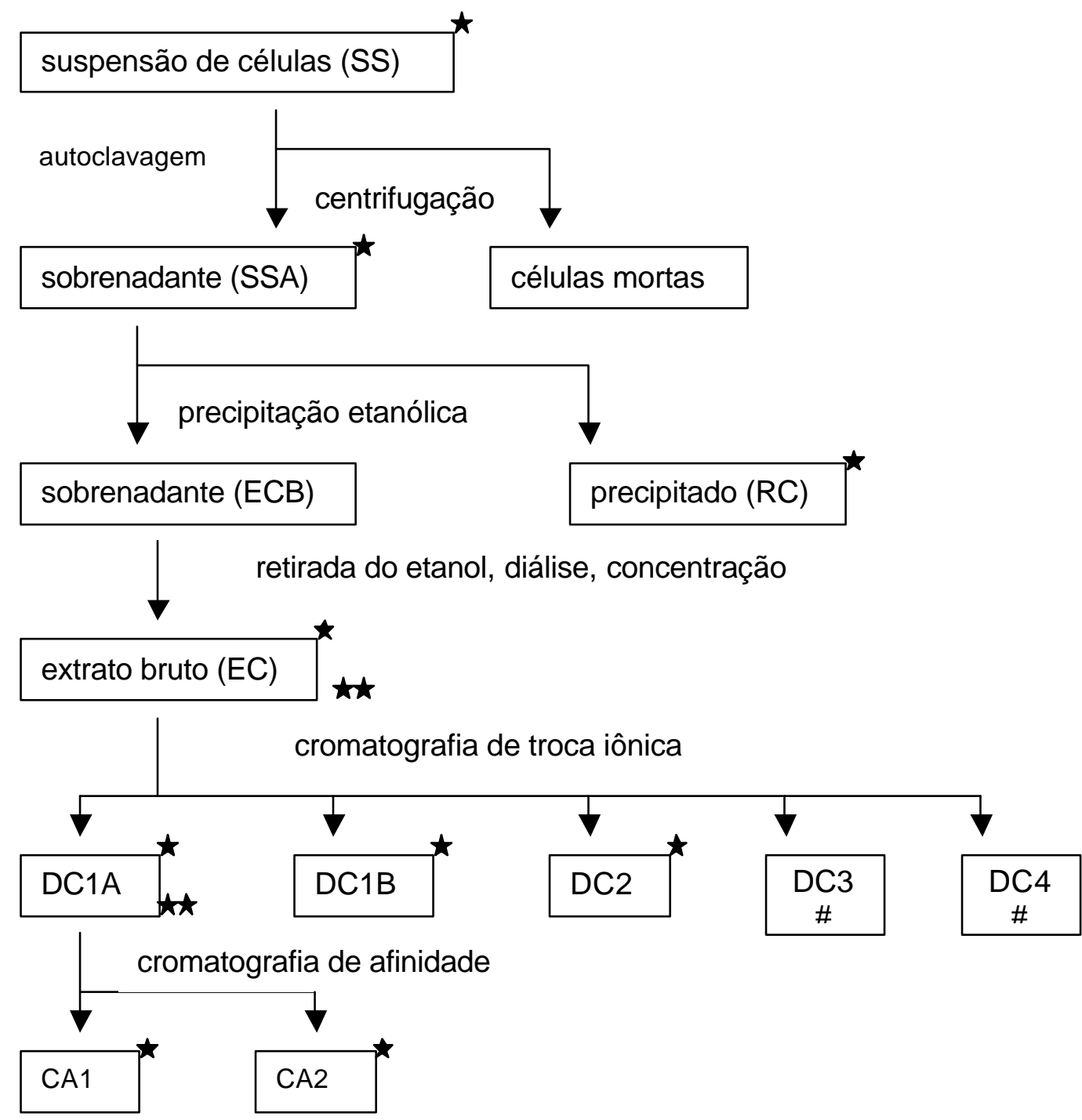

Figura 5 - Etapas gerais do processo de extração e separação de elicitores da parede celular de Saccharomyces cerevisiae. As frações marcadas com $\star$ foram utilizadas em testes com cotilédones e/ou plantas de soja e pepino. As frações marcadas com $\star \star$ foram as de maior poder elicitor nos testes com cotilédones e/ou plantas de soja e pepino e seguiram para a etapa seguinte de separação. As frações marcadas com \# não apresentavam concentração significativa de carboidratos e, por isso, não foram usadas nos testes de indução. 


\subsection{Fungos}

Colletotrichum lagenarium (Berk et Mont) - o fungo foi isolado a partir de lesões em fruto de pepino caipira comprado em Campinas-SP. O isolado foi mantido em meio de aveia (aveia em flocos finos), sob luz fluorescente constante à temperatura de $23^{\circ} \mathrm{C}$, em placa Pirex vedada com filme plástico. O fungo foi reisolado periodicamente de folhas de pepino infectadas, herbarizadas.

Microsphaera diffusa Cke. \& Pk.- o isolado foi obtido em campo comercial de soja em Holambra-SP e foi mantido em plantas de soja cv. IAC-8.2, envasadas e crescidas em casa de vegetação, sob condições ambientais.

\subsection{Pepino - Produção das plantas, tratamento e inoculação}

Suspensão de esporos de C. lagenarium - os conídios foram obtidos de colônias com 7 a 14 dias de idade. A superfície das colônias foi raspada suavemente com uma alça, assepticamente e, os conídios, suspensos em água. A suspensão foi filtrada em duas camadas de gaze e a concentração ajustada para $1 \mathrm{x}$ $10^{5}$ ou $5 \times 10^{4}$ conídios/mL (com auxílio de hematocitômetro) para inoculação de plântulas ou plantas, respectivamente. À suspensão de conídios foi adicionado Tween 20 na concentração de 0,10 ou $0,01 \%(v / v)$ conforme a inoculação fosse realizada em plantas ou plântulas. O inóculo obtido foi resultado de reisolamento do fungo, a partir de lesões em folhas de pepino.

Produção e inoculação de plantas de pepino - as sementes foram plantadas em bandejas contendo substrato agrícola Plant-mix e mantidas em casa de vegetação sob condições ambientais. Uma semana após o plantio as plantas foram transferidas para vasos, autoclavados, de $20 \mathrm{~cm}$ de diâmetro contendo solo também autoclavado. Com 14 dias de idade (primeira folha parcialmente expandida) as plantas foram tratadas com os preparados e 3 dias depois do tratamento foram inoculadas com a suspensão de esporos de $C$. lagenarium. A inoculação foi realizada no final da tarde, com auxílio de aspersor manual. As plantas inoculadas foram mantidas por $24 \mathrm{~h}$ em 
câmara úmida. Tanto as bandejas como os vasos foram mantidos em casa de vegetação em condições ambientais.

Produção e inoculação de plântulas de pepino - as sementes de pepino foram plantadas em bandejas contendo substrato agrícola Plant-mix e mantidas em câmara de crescimento sob regime de $16 \mathrm{~h}$ de luz (lâmpadas fluorescentes) e $8 \mathrm{~h}$ de escuro a $26^{\circ} \mathrm{C}$. Cinco dias após a semeadura (cotilédones com cerca de $1,5 \mathrm{~cm}$ ) as plântulas foram retiradas das bandejas e tiveram as raízes lavadas duas vezes com água. As plântulas foram tratadas com os preparados e transferidas para tubos de ensaio contendo $5 \mathrm{~mL}$ de água. Três ou sete dias após o tratamento, as plântulas foram inoculadas por imersão (5 s) em suspensão de conídios de $C$. lagenarium, e mantidas em câmara úmida por $24 \mathrm{~h}$. A partir do tratamento elicitor, a temperatura da câmara de crescimento foi reduzida para $23,5^{\circ} \mathrm{C}$.

Tratamento elicitor - a concentração dos preparados elicitores foi ajustada, com base nos carboidratos presentes (equivalentes de glucose $/ \mathrm{mL}$ ), de modo que todos os preparados de um mesmo experimento tivessem a mesma concentração. As plantas de pepino foram tratadas por imersão (5 s) da primeira folha verdadeira no preparado elicitor com gasto de $1,5 \mathrm{~mL}$ de preparado/planta. Já as plântulas foram tratadas, uma a uma, pela imersão ( $5 \mathrm{~s}$ ) dos cotilédones nos preparados elicitores, com gasto de $0,1 \mathrm{~mL}$ de preparado/plântula.

Desenho experimental - os ensaios com plantas e os ensaios com plântulas de pepino foram conduzidos com 5 repetições. No caso de plantas, cada repetição foi representada por 1 vaso contendo 4 plantas. Já no caso de plântulas, cada repetição foi composta por 4 tubos de ensaio (mantidos em uma mesma linha do suporte de tubos), cada qual com 1 plântula. As plântulas que formavam uma repetição eram inoculadas juntas. Cada experimento foi realizado duas vezes.

Avaliação dos sintomas - a avaliação foi realizada 7 ou 5 dias após a inoculação, conforme o ensaio fosse realizado com plantas ou plântulas de pepino. A severidade de antracnose foi determinada pela relação $\mathrm{cm}^{2}$ de área doente/ $\mathrm{cm}^{2}$ de área sadia das folhas ou cotilédones tratados. 
Em todos os ensaios com pepino, o Acibenzolar-S-metil foi usado como padrão de indução de resistência, na concentração de 50 ppm. Como controle foi utilizado água destilada.

\subsection{Determinação da concentração de fenóis livres e ligados}

Preparo e coleta das amostras - o tratamento elicitor foi realizado com a fração CA2 na concentração de $50 \mu \mathrm{g} / \mathrm{mL}$ de equivalentes de glucose. Tanto o tratamento elicitor como a inoculação bram realizados como descrito anteriormente para os testes com plântulas de pepino. As amostras foram coletadas imediatamente antes do tratamento elicitor (T0), três dias após o tratamento elicitor (imediatamente antes da inoculação -T1), 24, 48, 72 e 96 h após a inoculação (T2, T3, T4 e T5, respectivamente).

Determinação da concentração de fenóis - a determinação da concentração de fenóis livres e ligados foi realizada de acordo com o método descrito por Kofalvi \& Nassuth (1994). Três cotilédones de pepino, com cerca de 0,3 g, foram destacados das plântulas e imediatamente macerados em almofariz com nitrogênio líquido até a obtenção de um pó fino. Os fenóis foram extraídos com $4 \mathrm{~mL}$ de metanol $50 \%$ por $1,5 \mathrm{~h}$ a $80^{\circ} \mathrm{C}$. O extrato foi resfriado e centrifugado a $20.000 \mathrm{~g}$ por $15 \mathrm{~min}$ e o sobrenadante utilizado para a determinação de fenóis livres, pela reação de FolinCiocalteau. Ao precipitado formado na centrifugação foram adicionados $2 \mathrm{~mL}$ de $\mathrm{NaOH}$ $0,5 \mathrm{~N}$ para a saponificação de fenóis ligados à parede celular. Vinte e quatro horas após a adição da base a mistura foi neutralizada pela adição de $0,5 \mathrm{~mL}$ de $\mathrm{HCl} 2 \mathrm{~N} \mathrm{e}$ centrifugada a $20.000 \mathrm{~g}$ por $15 \mathrm{~min}$. O sobrenadante foi utilizado para a determinação de fenóis ligados pela reação de Folin-Ciocalteau. Cada tratamento foi composto por cinco repetições, sendo que cada repetição foi formada por três cotilédones de plântulas diferentes.

O teste de Folin-Ciocalteau foi realizado pela adição de $3 \mathrm{~mL} \mathrm{Na}_{2} \mathrm{CO}_{3}$ (2\%) a $150 \mu \mathrm{L}$ do extrato aquoso de cada amostra. Após $5 \mathrm{~min}$, foram adicionados $150 \mu \mathrm{L}$ do reagente de Folin-Ciocalteau, diluído em água, na proporção 1:1 (v/v). Após 
20 min, foi realizada a determinação da absorbância da solução, em espectrofotômetro, a $750 \mathrm{~nm}$. A concentração de fenóis foi expressa em equivalentes de ácido clorogênico $(\mathrm{mg})$ por $\mathrm{mg}$ de tecido fresco. A curva padrão de fenóis foi determinada usando soluções de ácido clorogênico nas concentrações de 0, 10, 20, 30, 40, 50, 100 e $150 \mu \mathrm{g} / \mathrm{mL}$ (Apêndice 2).

\subsection{Determinação da atividade de peroxidases}

Preparo e coleta das amostras - o preparo e a coleta do material para análise da atividade de peroxidases foram realizados do mesmo modo que o descrito para fenóis.

Determinação da atividade de peroxidases - a determinação foi realizada conforme descrito por Dalisay \& Kuc (1995b) e Roncatto \& Pascholati (1998). Três cotilédones de pepino, com cerca de 0,3 g, foram destacados das plântulas e imediatamente macerados em almofariz com nitrogênio líquido até a obtenção de um pó fino. A extração das enzimas foi realizada pela adição de $4 \mathrm{~mL}$ de tampão fosfato $0,01 \mathrm{M}(\mathrm{pH} 6,0)$ a $4^{\circ} \mathrm{C}$. O extrato foi centrifugado a $20.000 \mathrm{~g}$ por $25 \mathrm{~min}$ a $4^{\circ} \mathrm{C}$ e 0 sobrenadante foi coletado com auxílio de uma pipeta Pasteur. Em uma cubeta de vidro, com capacidade de $3 \mathrm{~mL}$, foram adicionados $2,9 \mathrm{~mL}$ de tampão de reação $(0,153 \mu \mathrm{L}$ de $\mathrm{H}_{2} \mathrm{O}_{2}, 0,125 \mu \mathrm{L}$ de guaiacol em $50 \mathrm{~mL}$ de tampão de extração) a 0,1 mL do extrato vegetal (sobrenadante). A reação foi seguida espectofotometricamente pela alteração na absorção a $470 \mathrm{~nm}$. A atividade específica da enzima foi expressa em $\Delta$ abs $470 \mathrm{~nm} \cdot \mathrm{min}^{-1} \cdot \mathrm{mg}^{-1}$ proteína. A concentração de proteínas no extrato vegetal foi determinada pelo método de Bradford (1976).

\subsection{Soja - Produção das plantas, tratamento e inoculação}

Produção e inoculação de plantas de soja - as sementes de soja foram plantadas em bandejas contendo substrato agrícola Plant-mix e mantidas em casa de 
vegetação sob condições ambientais. Uma semana após o plantio, as plantas foram transferidas para vasos, autoclavados, de $20 \mathrm{~cm}$ de diâmetro contendo solo também autoclavado (4 plantas por vaso). Uma semana após o transplantio foi realizado um desbaste, de modo que em cada vaso, fossem mantidas 2 plantas. As bandejas e as plantas foram mantidas em casa de vegetação, sob condições ambientais. As plantas fonte, nas quais foi mantido o inóculo de $M$. diffusa, foram mantidas em outra casa de vegetação, distante cerca de $100 \mathrm{~m}$ da primeira.

Tratamento elicitor - quatro semanas após o plantio, as duas folhas mais novas das plantas foram tratadas com as preparações elicitoras. $O$ tratamento foi realizado com uma gaze umedecida nas preparações e esfregada, levemente, nas folhas. Como controle foi utilizada água destilada. As preparações elicitoras foram diluídas de modo que a concentração de carboidratos fosse a mesma para todos os tratamentos a serem comparados.

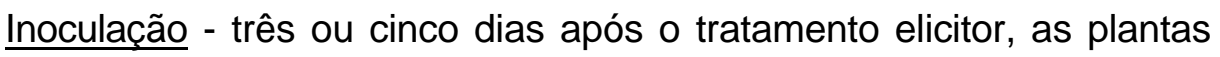
foram transferidas para a casa de vegetação que continha as plantas fonte. Um dia antes da inoculação, as plantas fonte foram agitadas, manualmente, de modo que os conídios velhos fossem dispersos. As plantas tratadas foram arranjadas ao redor dos vasos das plantas fonte, na proporção de 1 planta fonte para cada 6 plantas tratadas. Os vasos das plantas fonte foram mantidos cerca de $30 \mathrm{~cm}$ mais altos que os demais vasos, para que houvesse infecção natural. Após 3 dias, os vasos de plantas fonte foram mantidos a distância das plantas tratadas.

Desenho experimental - todos os ensaios realizados com soja foram conduzidos com pelo menos 5 repetições. Cada repetição era representada por 1 vaso contendo 2 plantas.

Avaliação dos sintomas - a avaliação foi realizada 12 dias após a inoculação. A severidade do oídio foi determinada pela relação $\mathrm{cm}^{2}$ de área doente/ $\mathrm{cm}^{2}$ de área sadia das duas folhas tratadas. 
Como controle, nos ensaios com soja, as plantas foram tratadas com água destilada.

\subsection{Bioensaio com cotilédones de soja}

Sementes de soja cv. IAC-8.2 foram plantadas em bandejas contendo solo autoclavado e mantidas em casa de vegetação. Os cotilédones de plantas com 9 dias de idade foram retirados das plântulas e lavados com água destilada várias vezes. A última lavagem dos cotilédones foi feita com água esterilizada. Na face abaxial dos cotilédones foi feito um corte superficial e, sobre esse corte, depositada uma gota de $75 \mu \mathrm{L}$ da preparação elicitora ou de água destilada. Os cotilédones foram arranjados em placas de petri (seis por placa) forradas com 3 discos de papel de filtro, umedecidos com água esterilizada. As placas (tampadas, mas não vedadas) foram mantidas a $26{ }^{\circ} \mathrm{C}$, no escuro. Após $20 \mathrm{~h}$, os cotilédones foram agitados com $10 \mathrm{~mL}$ de água destilada por 1 hora para a extração de gliceolinas. A solução foi filtrada em papel de filtro Whatman $n^{\circ} 41$ e a absorbância determinada em 285 nm (Hahn \& Albersheim, 1978). Cada ensaio foi conduzido com pelo menos cinco repetições e repetido pelo menos três vezes.

\subsection{Testes de fungitoxidez in vitro}

As frações EC e DC2 foram incorporadas a meio batata-dextrose-ágar, morno ao toque, de modo que a concentração de carboidratos no meio fosse de 200 e $50 \mu \mathrm{g} / \mathrm{mL}$ de equivalentes de glucose, respectivamente. Os preparados EC e DC2 foram esterilizados por filtragem em filtro de seringa Millipore $(0,2 \mu \mathrm{m})$. $\mathrm{O}$ meio foi vertido em placas de petri de vidro com $4 \mathrm{~cm}$ de diâmetro. Logo após o resfriamento do meio, discos com $0,35 \mathrm{~cm}$ de diâmetro foram transferidos de uma colônia de $C$. lagenarium com 14 dias de idade para as placas com meios recém vertidos. As placas foram vedadas e mantidas sob luz fluorescente constante a $23^{\circ} \mathrm{C}$. O ensaio foi conduzido com sete repetições. 
Medidas de crescimento micelial foram tomadas nos dois eixos das placas 2, 4, 5, 6 e 8 dias após a transferência dos discos. A área ocupada pelas colônias foi calculada com base na média de crescimento nos dois eixos. A velocidade de crescimento foi determinada para cada repetição e expressa em $\mathrm{cm}^{2} /$ dia.

No oitavo dia após a repicagem, foram adicionados $2 \mathrm{~mL}$ de água destilada a cada colônia. A superfície das colônias foi raspada, suavemente, com uma alça de vidro e as suspensões de esporos foram coletadas em tubos de ensaio. Cada amostra foi diluída 100 vezes para a determinação da concentração de esporos na suspensão (em hematocitômetro).

\subsection{Caracterização espectrofotometrica / espectrometrica dos elicitores}

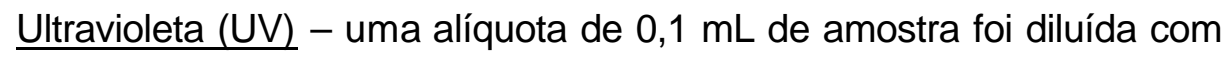
água em uma cubeta de quartzo de $1 \mathrm{~mL}$. A leitura de absorbância foi realizada de 340 a $190 \mathrm{~nm}$ em espectrofotômetro.

Infravermelho (IR) - um miligrama de amostra foi homogeneizado com $100 \mathrm{mg}$ de $\mathrm{KBr}$ e prensado para a formação de uma pastilha. O espectro na região do IR foi realizado no Instituto de Química (IQ) da Unicamp.

Ressonância magnético nuclear (RMN) - o espectro de ${ }^{13} \mathrm{C}$ foi obtido utilizando a freqüência de $125 \mathrm{MHz}$. A amostra foi dissolvida em água e o $\mathrm{CCl}_{4}$ foi usado como referência interna. Este espectro também foi obtido no IQ da Unicamp. 


\section{RESULTADOS}

\subsection{Purificação dos elicitores}

A autoclavagem e a retirada das células mortas levou à obtenção de uma solução amarelada (SSA). Após a precipitação etanólica, foi obtido um precipitado branco, pegajoso, de difícil solubilização em água $(\mathrm{RC})$. A solução etanólica reteve a cor amarelada que foi mantida após a evaporação do álcool. Após a diálise, a solução se tornou mais clara. A concentração de carboidratos e proteínas foi determinada em todas as etapas do processo (Tabela 1).

$\mathrm{Na}$ cromatografia de troca iônica da fração EC (Figura 6a), a maior parte da proteína aplicada a coluna (cerca de 90\%) foi adsorvida pela resina (Figura $6 b$ ). No que toca ao perfil de carboidratos eluídos, o $1^{\circ}$ e o $2^{\circ}$ picos (frações $D C 1 A$, DC1B e DC2) contribuiram, cada um, com cerca de $50 \%$ do total de carboidratos, sendo quase zero a concentração de carboidratos nas frações DC3 e DC4 (Figura 6c). O último pico, representado pela fração DC4, apresentou um máximo de absorção (a $280 \mathrm{~nm})$ 9,6 e 5,5 vezes maior que os máximos de absorção apresentados pelo $1^{\circ}$ e $2^{\circ}$ picos, respectivamente. Por estes dados era de se esperar que a participação de proteínas fosse maior na fração DC4 do que nas demais. No entanto, isso não é verdade. O último pico contribuiu com apenas $5 \%$ do total de proteínas (Figura 6b). As frações DC1A, DC1B e DC2 eram incolores, enquanto que as frações DC3A, DC3B e DC4 eram amareladas. As frações coloridas apresentavam um gradiente de tonalidade, sendo a fração DC3A a mais clara e a DC4 a mais escura.

$\mathrm{Na}$ cromatografia de afinidade apenas carboidratos, foram ligados à resina. A fração não ligada apresentou em sua composição cerca de $50 \%$ dos carboidratos e $100 \%$ das proteínas contidos na amostra DC1A, aplicada à coluna (Tabela 1). 
Tabela 1. Composição de cada uma das frações obtidas no processo de purificação, partindo de $206 \mathrm{~g}$ de levedura.

\begin{tabular}{|c|c|c|c|}
\hline & \multirow{2}{*}{ Fração } & \multicolumn{2}{|c|}{ Total na fração (mg) } \\
\hline & & Proteínas & Carboidratos \\
\hline \multirow{3}{*}{$\begin{array}{l}\text { Precipitação } \\
\text { etanólica }\end{array}$} & SSA & 468,5 & 544,3 \\
\hline & EC & 62,4 & 190,9 \\
\hline & $\mathrm{RC}$ & 78,5 & 49,4 \\
\hline $\begin{array}{l}\text { Diálise e } \\
\text { concentração } \\
\text { (da precipitação) }\end{array}$ & $\mathrm{EC}$ & 35,9 & 12,8 \\
\hline \multirow{6}{*}{$\begin{array}{l}\text { Cromatografia de } \\
\text { troca iônica } \\
\text { (CTI) }\end{array}$} & DC1A & 1,1 & 2,5 \\
\hline & DC1B & 1,5 & 3,0 \\
\hline & DC2 & 17,4 & 5,3 \\
\hline & DC3A & 5,6 & 0,2 \\
\hline & DC3B & 7,0 & 0,3 \\
\hline & DC4 & 1,7 & 0,2 \\
\hline $\begin{array}{l}\text { Diálise e } \\
\text { concentração } \\
\text { (da CTI) }\end{array}$ & DC1A & 0,7 & 1,6 \\
\hline \multirow{2}{*}{ 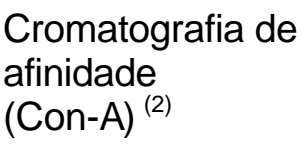 } & CA1 & 0,13 & 0,54 \\
\hline & CA2 & zero & 0,47 \\
\hline \multirow{2}{*}{$\begin{array}{l}\text { Diálise e } \\
\text { concentração } \\
\text { (da Con-A) }\end{array}$} & CA1 & 0,051 & 0,300 \\
\hline & CA2 & zero & 0,336 \\
\hline
\end{tabular}

(1) aplicação da fração EC àcoluna de troca iônica (35,9 mg de proteínas e 12,79 mg de carboidratos).

(2) aplicação da fração DC1A àcoluna de afinidade $(0,71 \mathrm{mg}$ de proteínas e 1,58 mg de carboidratos) 

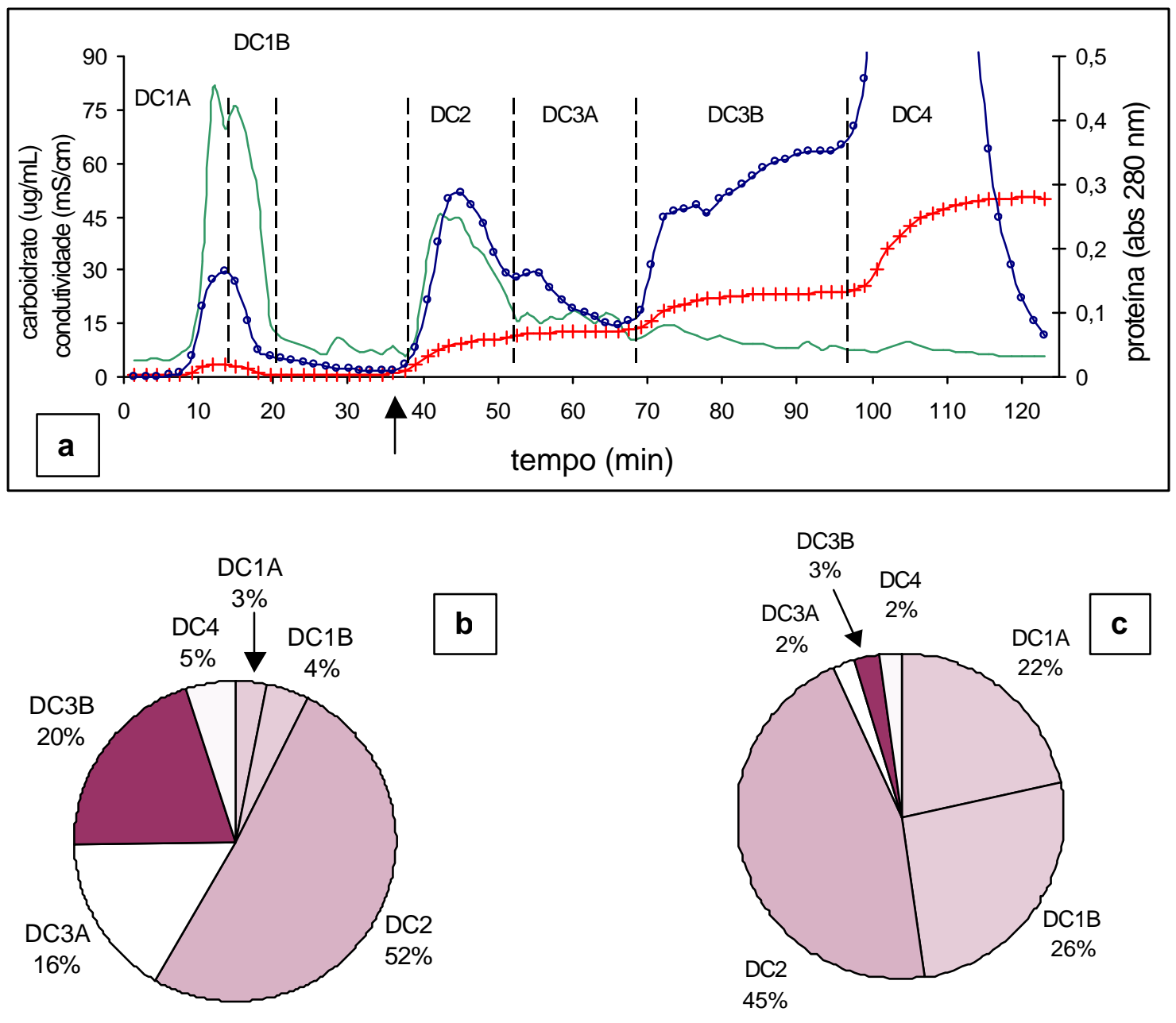

Figura 6 - (a). Cromatografia de troca iônica (CTI) da fração EC (sobrenadante dialisado da precipitação etanólica). Uma amostra de $25 \mathrm{~mL}$ foi aplicada ao leito da coluna empacotada com a resina DEAECelulose, equilibrada e eluída com tampão Tris- $\mathrm{HCl} 0,01 \mathrm{M}(\mathrm{pH} 8,0)$. Para eluição do material adsorvido à resina, foram usadas soluções de $\mathrm{NaCl}$ a $0,115 \mathrm{M}$ (30 min), 0,215 M (30 min) e 0,50 M (45 min). A seta indica o início da eluição com $\mathrm{NaCl}$. As frações coletadas foram reagrupadas, conforme o perfil de carboidratos e proteínas para formação de 5 novas frações: DC1A, DC1B, DC2, DC3A, DC3B e DC4. Carboidratos (-); proteínas (-o-); condutividade (+); (b). proteínas - distribuição percentual em cada fração da CTI; (c). carboidratos - distribuição percentual em cada fração da CTI. 
A liofilização da amostra CA2 produziu $10 \mathrm{mg}$ de um pó braanco de aparência cotonosa. O rendimento das etapas de purificação foi cerca de 0,005\% em peso (peso da fração CA2 x 100/ peso de levedura) e de 0,06\% em termos de carboidratos (mg de carboidratos na fração CA2 x 100/ mg carboidratos na fração SSA) (os demais rendimentos são apresentados no Anexo).

\subsection{Ensaios de proteção com pepino}

No primeiro ensaio de proteção, plantas de pepino foram tratadas com os preparados SS, SSA, EC e RC (o primeiro na concentração de $20 \mathrm{~g} / \mathrm{L}$ de levedura e os demais na concentração de $300 \mu \mathrm{g} / \mathrm{mL}$ de equivalentes de glucose). As plantas adultas tratadas com o preparado EC foram as que apresentaram menor severidade de antracnose. Nenhum dos outros preparados apresentou proteção significativa. Do mesmo modo, plântulas tratadas com SSA e SS, nas mesmas concentrações, também não apresentaram redução na severidade da doença (Tabela 2, Figura 7).

Tabela 2. Efeito do tratamento de plântulas de pepino com frações de Saccharomyces cerevisiae na manifestação de sintomas de antracnose.

\begin{tabular}{cc}
\hline Tratamento & $\begin{array}{l}\text { Severidade de antracnose em } \\
\text { plântulas (\% de área doente) }\end{array}$ \\
\hline Controle & $19,3 \pm 1,7$ \\
SS & $14,6 \pm 0,9$ \\
SSA & $13,0 \pm 1,3$ \\
\hline
\end{tabular}

As plântulas com 5 dias de idade tiveram seus cotilédones tratados água ou com: SS = suspensão de células de levedura $(20 \mathrm{~g} / \mathrm{L})$; SSA = sobrenadante da suspensão de células autoclavada e, inoculadas com suspensão de conídios de $C$. lagenarium $\left(1 \times 10^{5}\right)$. A severidade da doença, nos cotilédones, foi quantificada 5 dias após a inoculação Os valores representam a média de 5 repetições, seguidos por \pm erro padrão da média . Não houve diferença significativa entre as médias pelo teste $F$ a $5 \%$ de probabilidade. $\mathrm{CV}=20,54 \%$. 


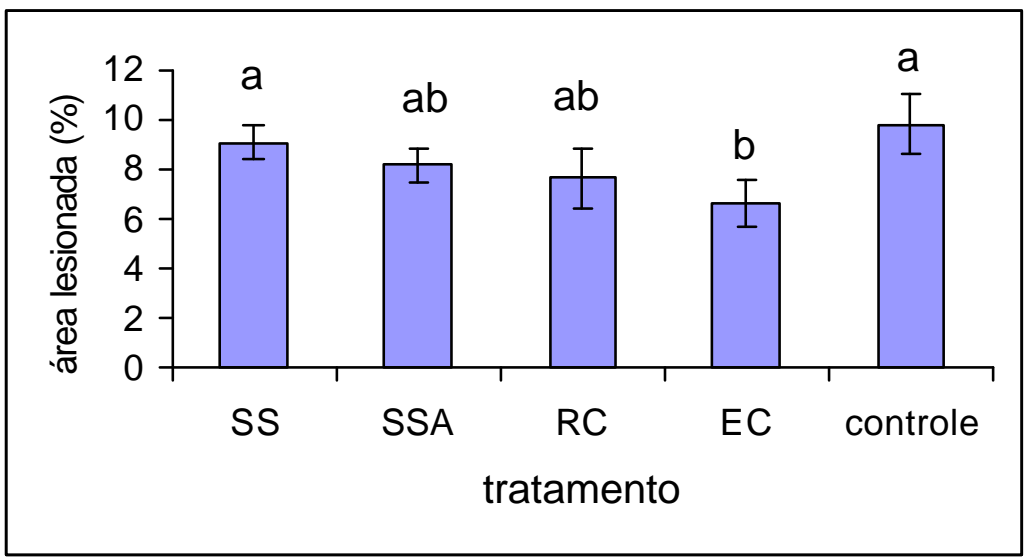

Figura 7 - Efeito do tratamento de plantas de pepino com frações de Saccharomyces cerevisiae na manifestação de sintomas de antracnose. As plantas com 14 dias de idade tiveram sua $1^{\circ}$ folha verdadeira tratada com água ou com: $\mathrm{SS}=$ suspensão de células de levedura $(20 \mathrm{~g} / \mathrm{L}) ; \mathrm{SSA}=$ sobrenadante da suspensão de células autoclavada; $\mathrm{EC}=$ sobrenadante da precipitação etanólica; $\mathrm{RC}$ = precipitado da precipitação etanólica. A concentração dos preparados foi ajustada para $300 \mu \mathrm{g} / \mathrm{mL}$ de equivalentes de glucose. Três dias após o tratamento, as plantas foram inoculadas com suspensão de conídios de $C$. lagenarium $\left(5 \times 10^{4}\right)$. A severidade da doença foi quantificada 7 dias após a inoculação. As barras representam a média de 5 repetições. Letras distintas acima das barras representam diferença significativa entre tratamentos pelo teste $\mathrm{F}$ a $5 \%$ de probabilidade. Cada barra representa a média de 5 repetições. CV $=26,41 \%$.

Em um segundo ensaio conduzido com plântulas de pepino, foram testadas 2 doses de carboidratos ( 200 e $400 \mu \mathrm{g} / \mathrm{mL}$ ) em equivalentes de glucose e dois intervalos de tempo entre o tratamento e a inoculação ( 3 e 7 dias). Foi possível observar que a fração EC conferiu maior proteção quando usada na dose mais baixa e que a proteção foi efetiva nos dois intervalos de tempo testados (Figura 8). 


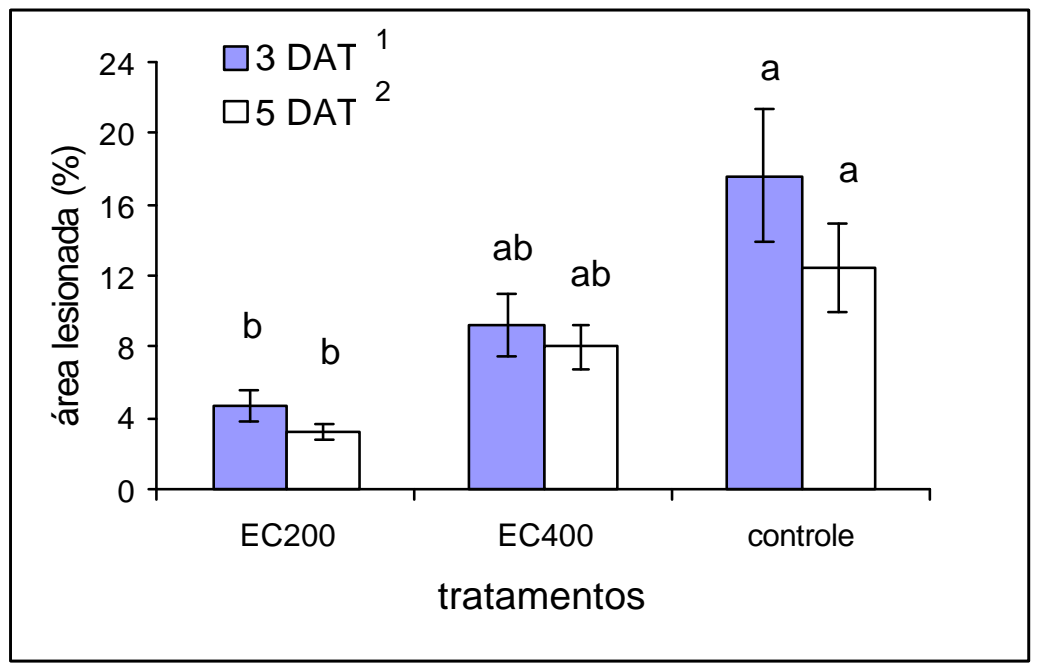

Figura 8 - Efeito do tratamento de plântulas de pepino com o preparado EC, obtido de Saccharomyces cerevisiae, em diferentes doses e intervalos de tempo entre o tratamento e a inoculação, na manifestação de sintomas de antracnose. As plântulas com 5 dias de idade tiveram seus cotilédones tratados com água ou com o sobrenadante da precipitação etanólica (EC). A concentração de EC foi ajustada para 200 ou $400 \mu \mathrm{g} / \mathrm{mL}$ de equivalentes de glucose. Três ou sete dias após o tratamento (3 DAT e 7 DAT, respectivamente) as plântulas foram inoculadas com suspensão de conídios de $C$. lagenarium $\left(1 \times 10^{5}\right)$. A severidade da doença foi quantificada 5 dias após a inoculação. Letras distintas acima de barras da mesma cor representam diferença significativa entre tratamentos pelo teste $\mathrm{F}$ a $5 \%$ de probabilidade. Cada barra representa a média de 5 repetições. (1). CV = $56,82 \%$; (2). CV = 44,55\%.

A fração EC, por ter maior poder de proteção (figura 7), foi fracionada por CTI originando três frações contendo carboidratos: DC1A, DC1B e DC2 (Figura 6a). Estas três frações foram confrontadas em testes de proteção com plântulas de pepino nas concentrações de 50 e $100 \mu \mathrm{g} / \mathrm{mL}$ em equivalentes de glucose. Das três frações, a DC1A foi a que apresentou maior poder de proteção, na concentração mais alta (Figura 9). 


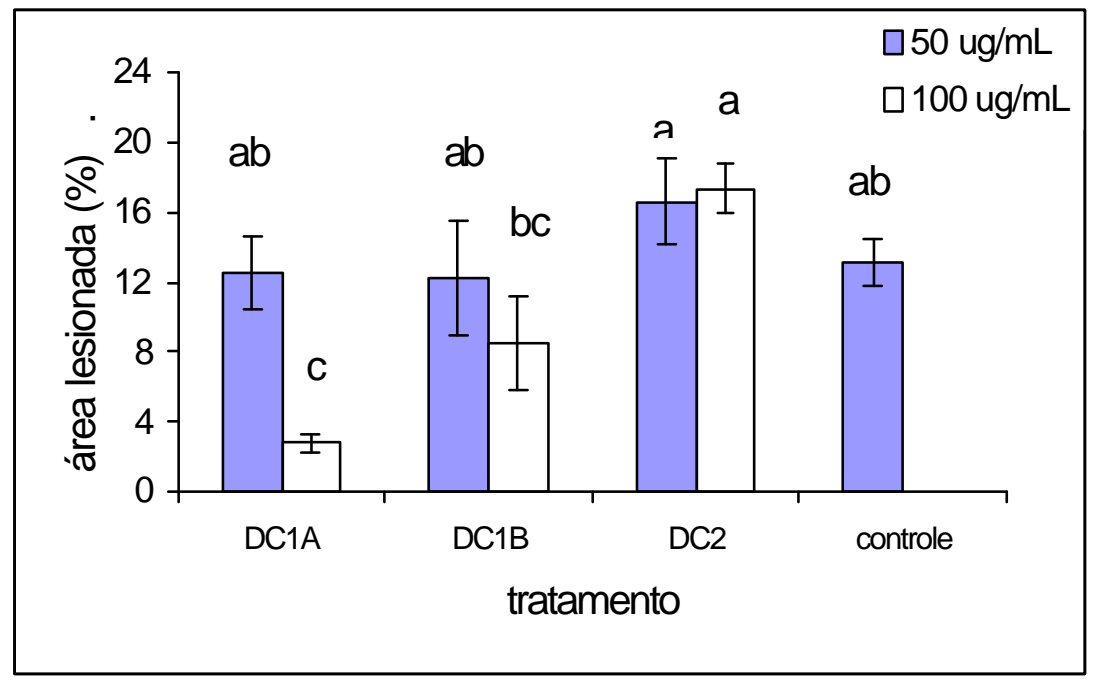

Figura 9 - Efeito do tratamento de plântulas de pepino com as frações de Saccharomyces cerevisiae resultantes da cromatografia de troca iônica, em 2 doses, na manifestação de sintomas de antracnose. As plântulas com 5 dias de idade tiveram seus cotilédones tratados com água ou com as frações da cromatografia de troca iônica que continham carboidratos em sua composição (DC1A, DC1B e DC2). A concentração das frações foi ajustada para 50 ou $100 \mu \mathrm{g} / \mathrm{mL}$ de equivalentes de glucose. Três dias após o tratamento as plântulas foram inoculadas com suspensão de conídios de $C$. lagenarium $\left(1 \times 10^{5}\right)$. A severidade da doença foi quantificada 5 dias após a inoculação. Letras distintas acima das barras representam diferença significativa entre tratamentos pelo teste $F$ a $5 \%$ de probabilidade. Cada barra representa a média de 5 repetições. $\mathrm{CV}=$ $36,15 \%$.

A fração DC1A foi separada por cromatografia de afinidade nas frações CA1 (não ligada a resina) e CA2 (ligada a resina). Em testes de proteção com plântulas de pepino, as 2 frações, na concentração de $50 \mu \mathrm{g} / \mathrm{mL}$ em equivalentes de glucose, foram capazes de reduzir a severidade de antracnose quando comparadas com o controle. No entanto, a proteção conferida pelo tratamento com as frações CA1 e CA2 não diferiram estatisticamente entre si (Figura 10). 


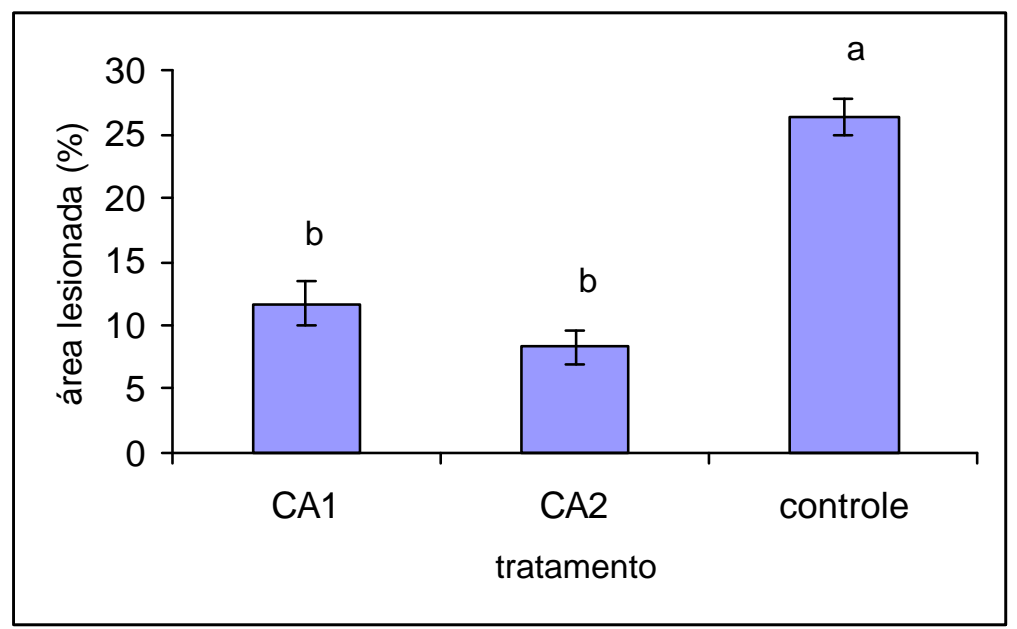

Figura 10 - Efeito do tratamento de plântulas de pepino com as frações de Saccharomyces cerevisiae resultantes da cromatografia de afinidade na manifestação de sintomas de antracnose. As plântulas com 5 dias de idade tiveram seus cotilédones tatados com água ou com as frações da cromatografia de afinidade (CA1 = fração não ligada e CA2 $=$ fração ligada). A concentração das frações foi ajustada para 50 $\mu \mathrm{g} / \mathrm{mL}$ de equivalentes de glucose. Três dias após o tratamento as plântulas foram inoculadas com suspensão de conídios de $C$. lagenarium $\left(1 \times 10^{5}\right)$. A severidade da doença foi quantificada 5 dias após a inoculação. Letras distintas acima das barras representam diferença significativa entre tratamentos pelo teste $F$ a $5 \%$ de probabilidade. Cada barra representa a média de 5 repetições. $\mathrm{CV}=$ $25,07 \%$.

O tratamento de plantas e plântulas de pepino com ASM levou a supressão completa dos sintomas da doença na época da avaliação. 


\subsection{Atividade de peroxidases}

Para análise da atividade de peroxidases, plântulas de pepino foram tratadas com a fração CA2 (50 $\mu \mathrm{g} / \mathrm{mL}$ em equivalentes de glucose) e inoculadas com C. lagenarium. No $2^{\circ}$ e $3^{\circ}$ dia após a inoculação (T3 e T4), as plântulas tratadas com CA2 apresentaram atividade da enzima estatisticamente superior a atividade apresentada pelas plântulas tratadas com água (Figura 11). Nos demais tempos, não houve diferença significativa na atividade de peroxidases das plantas tratadas e do controle.

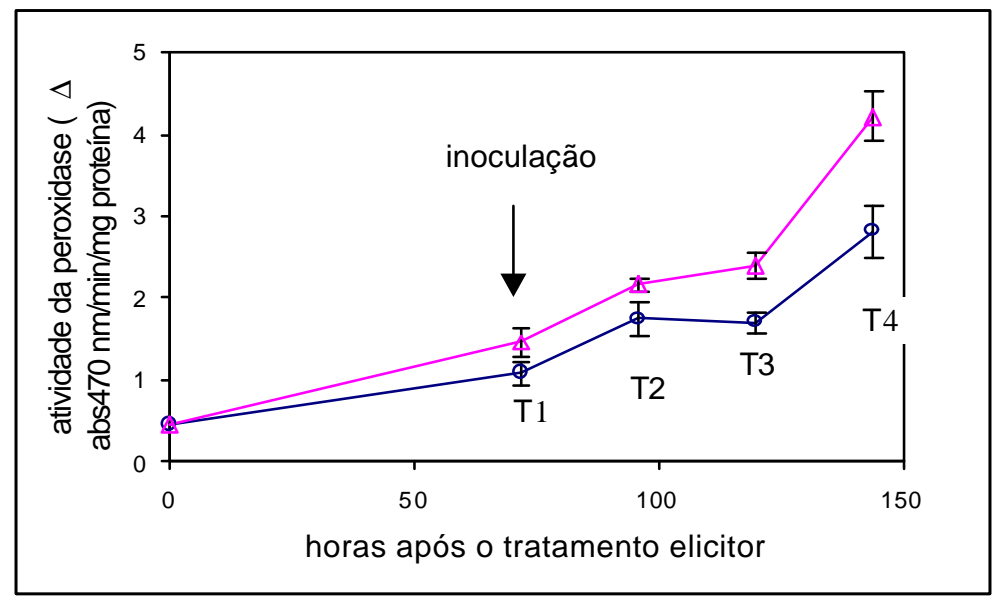

Figura 11 - Alteração na atividade da peroxidase resultante de tratamento elicitor. Os cotilédones das plântulas de pepino foram tratados com água (-o-) ou com a fração de Saccharomyces cerevisiae ligada a Con-A (CA2;- - -) e 3 dias depois inoculadas com Colletotrichum lagenarium. Amostras para análise da enzima foram retiradas imediatamente antes do tratamento (T0); $72 \mathrm{~h}$ após o tratamento (imediatamente antes da inoculação; T1); 24; 48; 72 e $96 \mathrm{~h}$ após a inoculação (T2, T3, T4 e T5; respectivamente). O ponto T5 (10,66 e 12,35 $\Delta$ abs $470 \mathrm{~nm} / \mathrm{min} / \mathrm{mg}$ de proteína para água e CA2, respectivamente) não é apresentado no gráfico. As barras representam \pm 0 erro padrão da média de 5 repetições. Apenas em T3 e T4 houve diferença significativa, entre o controle e o tratamento com CA2, pelo teste $\mathrm{F}$ a $5 \%$ de probabilidade. $\mathrm{CV}_{\mathrm{T} 1}=20,24 ; \mathrm{CV}_{\mathrm{T} 2}=19,45 ; \mathrm{CV}_{\mathrm{T} 3}=11,62 ; \mathrm{CV}_{\mathrm{T} 4}=14,31$; $\mathrm{CV}_{\mathrm{T} 5}=20,26 \%$. 


\subsection{Concentração de fenóis livres e ligados}

As plântulas foram tratadas e inoculadas do mesmo modo que aquelas utilizadas para determinação da atividade de peroxidases. Não houve diferença significativa, no conteúdo de fenóis livres nem ligados entre as plantas controle e as plantas tratadas (Tabela 3).

Tabela 3. Efeito do tratamento de plântulas de pepino com a fração de Saccharomyces cerevisiae ligada a Con-A (CA2) no acúmulo de fenóis livres e ligados.

Acúmulo de fenóis (mg eq. ácido clorogênico/mg tecido fresco)

\begin{tabular}{ccccccc} 
& \multicolumn{2}{c}{ Fenóis livres } & \multicolumn{3}{c}{ Fenóis ligados } \\
Tempo & Controle & CA2 & CV (\%) & Controle & CA2 & CV (\%) \\
\hline T0 & $0,88 \pm 0,04$ & & & $3,41 \pm 0,09$ & & \\
T1 & $0,74 \pm 0,05$ & $0,78 \pm 0,02$ & 10,33 & $2,12 \pm 0,09$ & $2,12 \pm 0,10$ & 14,54 \\
T2 & $0,81 \pm 0,12$ & $0,72 \pm 0,04$ & 29,91 & $2,13 \pm 0,10$ & $1,96 \pm 0,02$ & 6,77 \\
T3 & $0,67 \pm 0,04$ & $0,68 \pm 0,05$ & 18,29 & $2,20 \pm 0,08$ & $2,09 \pm 0,05$ & 7,97 \\
T4 & $0,64 \pm 0,06$ & $0,55 \pm 0,03$ & 20,41 & $1,74 \pm 0,08$ & $1,67 \pm 0,07$ & 10,6 \\
T5 & $0,86 \pm 0,07$ & $0,72 \pm 0,04$ & 12,54 & $1,88 \pm 0,07$ & $1,73 \pm 0,04$ & 5,39 \\
\hline
\end{tabular}

As plântulas com 5 dias de idade tiveram seus cotilédones tratados com água ou com a fração de $S$. cerevisiae ligada a Con-A (CA2; $50 \mu \mathrm{g} / \mathrm{mL}$ em equivalentes de glucose). Três dias após o tratamento as plântulas foram inoculadas com suspensão de conídios de C. lagenarium $\left(1 \times 10^{5}\right)$. Amostras para análise de fenóis foram retiradas imediatamente antes do tratamento (T0); $72 \mathrm{~h}$ após o tratamento (imediatamente antes da inoculação; T1); 24; 48; 72 e 96 h após a inoculação (T2, T3, T4 e T5; respectivamente). Os valores representam a média de 5 repetições seguidos por \pm erro padrão da média. Não houve diferença significativa entre 0 controle e as plantas tratadas com CA2 pelo teste $\mathrm{F}$ a $5 \%$ de probabilidade. 


\subsection{Bioensaios com cotilédones de soja}

O tratamento de cotilédones de soja com frações da parede de $S$. cerevisiae obtidas por autoclavagem levou ao acúmulo de gliceolinas. Estas fitoalexinas são incolores, e têm máximo de absorção em 285 nm, na região do ultravioleta (Figura 12).

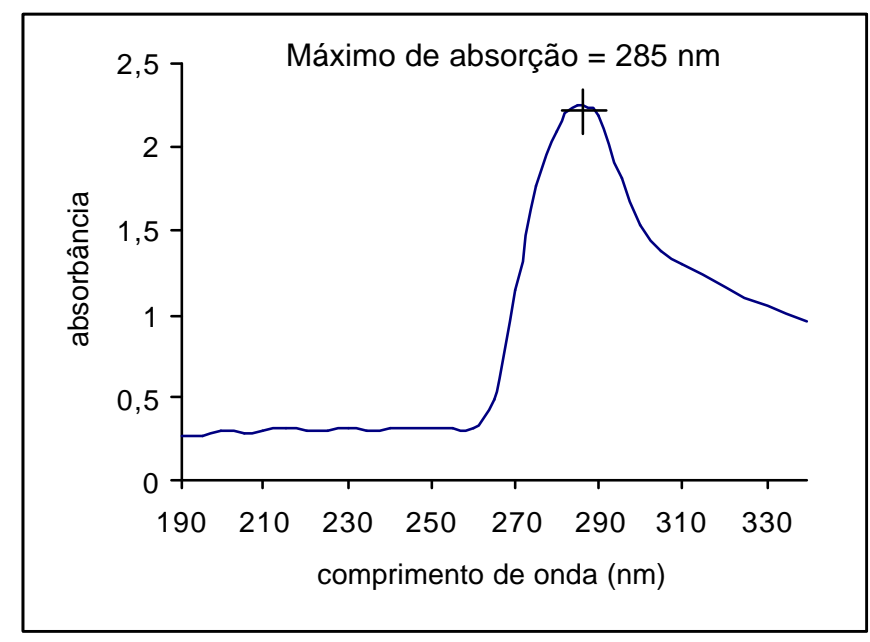

Figura 12 - Espectro na região do ultravioleta de gliceolinas extraídas de cotilédones de soja tratados com elicitores presentes na parede de Saccharomyces cerevisiae.

Nos testes conduzidos com cotilédones de soja, todos os preparados testados (na concentração de $100 \mu \mathrm{g} / \mathrm{mL}$ em equivalentes de glucose) foram capazes de induzir síntese de gliceolinas. A fração EC foi o preparado que apresentou maior poder elicitor (Figura 13). 


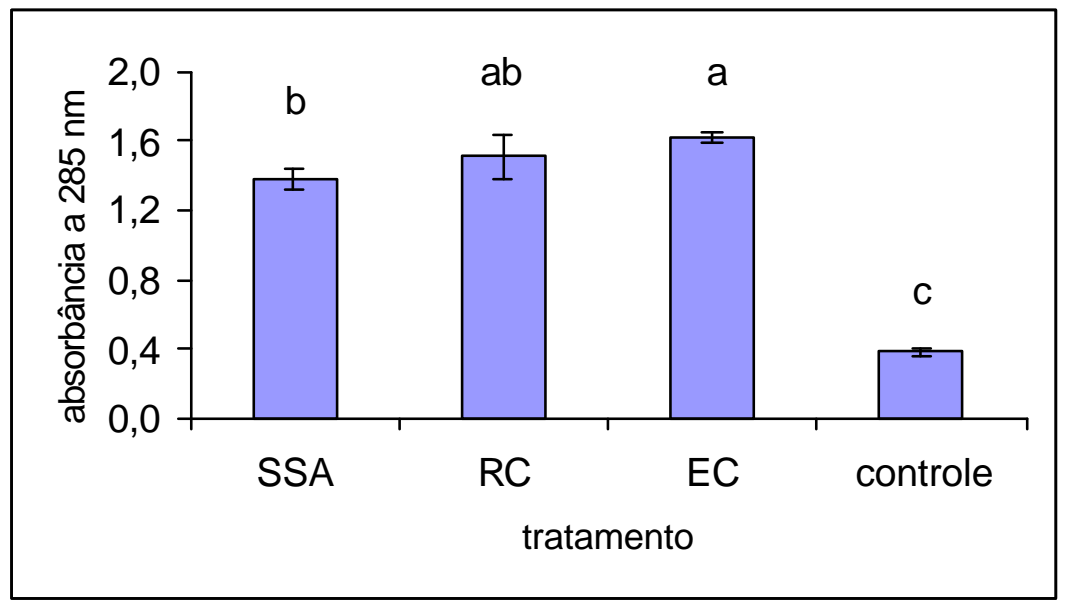

Figura 13 - Efeito do tratamento de cotilédones de soja com elicitores extraídos de Saccharomyces cerevisiae na produção de gliceolinas. Os cotilédones de plantas com 9 dias foram destacados e sobre um corte superficial na face abaxial dos cotilédones foram depositadas gotas de água ou dos seguintes preparados: SSA = sobrenadante da suspensão de células autoclavada; $\mathrm{EC}=$ sobrenadante da precipitação etanólica; $\mathrm{RC}=$ precipitado da precipitação etanólica. A concentração dos preparados foi ajustada para $100 \mu \mathrm{g} / \mathrm{mL}$ de equivalentes de glucose. Letras distintas acima das barras representam diferença significativa entre tratamentos pelo teste $\mathrm{F}$ a $5 \%$ de probabilidade. Cada barra representa a média de 5 repetições. $C V=11,05 \%$.

Para avaliar o efeito de doses de EC na síntese de gliceolina, foram realizados ensaios em que a dose de EC variou de 0 a $200 \mu \mathrm{g} / \mathrm{mL}$ de equivalentes de glucose. Quanto maior a dose, maior a síntese de gliceolina (Figura 14). 


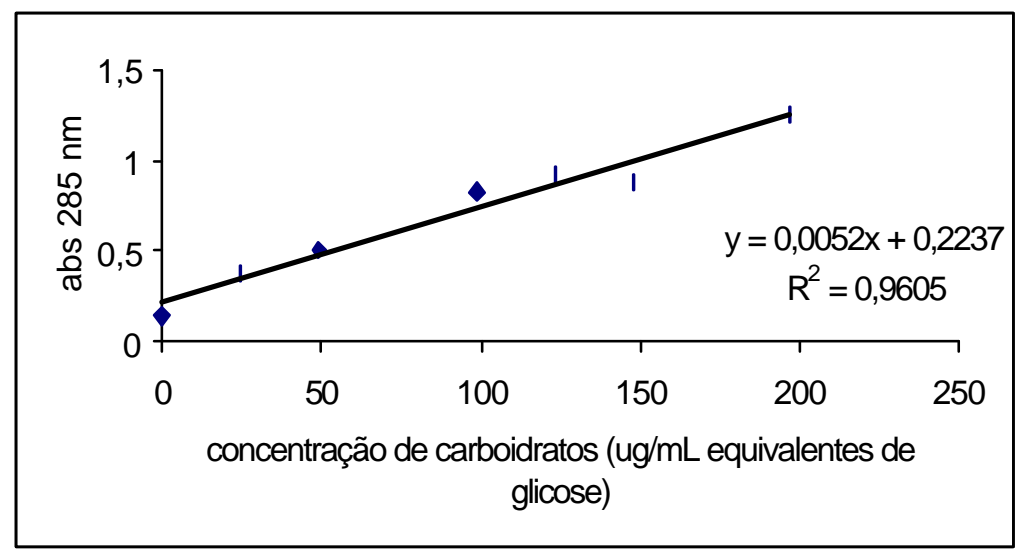

Figura 14 - Efeito de doses crescentes de carboidratos, presentes na fração EC de Saccharomyces cerevisiae, na síntese de gliceolina por cotilédones de soja.

A fração EC, por apresentar maior poder elicitor, foi fracionada por CTI originando três novas frações contendo carboidratos: DC1A, DC1B e DC2 (Figura 6a). As frações $\mathrm{DC1} A \mathrm{~A}$ e $\mathrm{DC1B}$ levaram à maior síntese de fitoalexinas do que o extrato bruto EC, sendo DC1B mais ativa que DC1A. No entanto, o poder elicitor da fração DC2 foi inferior ao da fração EC (Figura 15).

\subsection{Ensaios de proteção com plantas de soja}

Os primeiros testes de proteção foram conduzidos com os preparados SS ( $20 \mathrm{~g}$ de levedura/L) e SSA. A inoculação das plantas foi realizada 3 e 5 dias após os tratamentos. Neste experimento, devido a condições ambientais, a severidade da doença foi bastante baixa, e não houve diferença entre os tratamentos e o controle na manifestação do oídio (Tabela 4). 


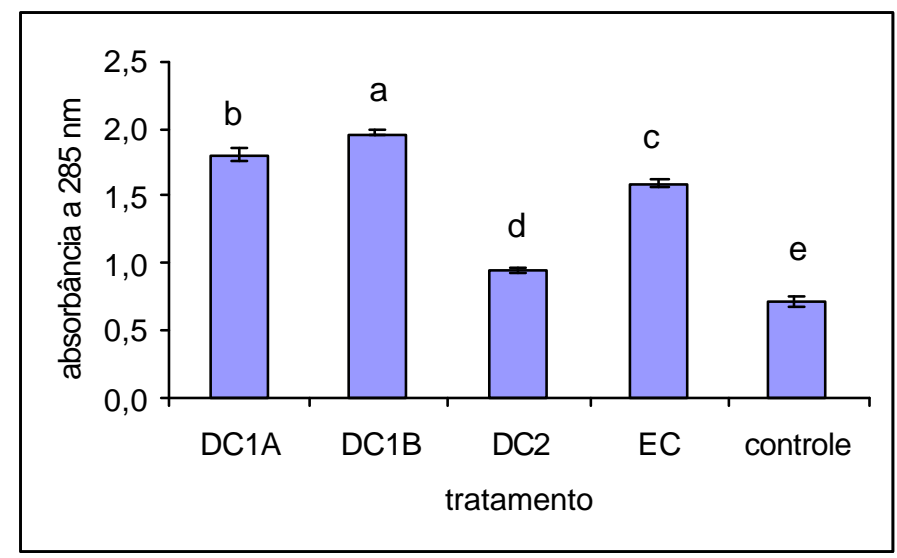

Figura 15 - Acúmulo de gliceolina em cotilédones de soja tratados com água ou com as frações de Saccharomyces cerevisiae resultantes da cromatografia de troca iônica (DC1A, DC1B e DC2) e com o extrato bruto (EC) na concentração de $100 \mu \mathrm{g} / \mathrm{mL}$ de equivalentes de glucose. Letras distintas acima das barras representam diferença significativa entre tratamentos pelo teste $\mathrm{F}$ a $5 \%$ de probabilidade. Cada barra representa a média de 5 repetições. $C V=5,96 \%$.

Tabela 4. Efeito do tratamento plantas de soja com diferentes preparados de Saccharomyces cerevisiae e intervalos de tempo entre o tratamento e a inoculação, na manifestação de sintomas de oídio.

\begin{tabular}{|c|c|c|}
\hline & \multicolumn{2}{|c|}{ Severidade de oídio (\% de área doente) } \\
\hline & $\begin{array}{l}\text { Plantas inoculadas } 3 \text { dias } \\
\text { após o tratamento } \\
\end{array}$ & $\begin{array}{l}\text { Plantas inoculadas } 5 \text { dias } \\
\text { após o tratamento }\end{array}$ \\
\hline Controle & $4,99 \pm 2,00$ & $1,96 \pm 0,19$ \\
\hline SS & $7,04 \pm 3,39$ & $2,84 \pm 0,50$ \\
\hline SSA & $6,61 \pm 2,94$ & $2,09 \pm 0,21$ \\
\hline
\end{tabular}

Plantas com 4 semanas foram tratadas com água ou com os seguintes preparados: SS = suspensão de células de Saccharomyces cerevisiae $(20 \mathrm{~g} / \mathrm{L}) ; \mathrm{SSA}=$ sobrenadante da suspensão de células autoclavada $(200 \mathrm{~g} / \mathrm{mL})$. Três ou sete dias após o tratamento as plantas foram inoculadas. A inoculação, natural, ocorreu pelo contato das plantas tratadas com plantas fonte infectadas. Os números representam a média de 5 repetições, seguidos por \pm erro padrão da média. Não houve diferença significativa entre os tratamentos pelo teste $F$ a $5 \%$ de probabilidade. (1). $C V=$ 96,19\%; (2). CV $=51,78 \%$. 
Em um segundo experimento as plantas foram tratadas com os preparados EC nas concentrações de 100, 200 e $400 \mu \mathrm{g} / \mathrm{mL}$ em equivalentes de glucose, com intervalo de 3 dias entre o tratamento e a inoculação. Também não houve diferença significativa entre os tratamentos e o controle na manifestação do oídio (Tabela 5).

Tabela 5. Efeito do tratamento plantas de soja com diferentes concentrações da fração EC da Saccharomyces cerevisiae, na manifestação dos sintomas de oídio.

\begin{tabular}{lc}
\hline & Severidade de oídio (\% de área doente) \\
\hline Controle & $34,80 \pm 7,72$ \\
EC $100 \mu \mathrm{g} / \mathrm{mL}$ & $43,71 \pm 12,08$ \\
EC $200 \mu \mathrm{g} / \mathrm{mL}$ & $33,50 \pm 3,5$ \\
EC $400 \mu \mathrm{g} / \mathrm{mL}$ & $28,05 \pm 9,18$ \\
\hline
\end{tabular}

Plantas com 4 semanas foram tratadas com o sobrenadante da precipitação etanólica (EC) nas concentrações de 100, 200 e $400 \mu \mathrm{g} / \mathrm{mL}$. Três dias após o tratamento as plantas foram inoculadas. A inoculação, natural, ocorreu pelo contato das plantas tratadas com plantas fonte infectadas. Os números representam a média de 6 repetições seguido por \pm 0 erro padrão da média. Não houve diferença significativa entre os tratamentos pelo teste $\mathrm{F}$ a $\mathrm{5} \% \mathrm{de}$ probabilidade. $\mathrm{CV}=45,48 \%$.

\subsection{Testes de fungitoxidez in vitro}

A incorporação das frações EC e DC2 a meio de cultura não alterou a velocidade de crescimento micelial do fungo $C$. lagenarium (Tabela 6). No entanto, a esporulação do fungo foi favorecida pelos dois preparados (Figura 16). 
Tabela 6. Efeito das frações EC e DC2 da Saccharomyces cerevisiae na velocidade de crescimento micelial de Colletotrichum lagenarium.

\begin{tabular}{cc}
\hline & Velocidade de crescimento micelial $\left(\mathrm{cm}^{2} /\right.$ dia $)$ \\
\hline Controle & $2,59 \pm 0,04$ \\
EC & $2,58 \pm 0,09$ \\
DC2 & $2,68 \pm 0,07$ \\
\hline
\end{tabular}

Os preparados EC (sobrenadante da precipitação etanólica) e DC2 (Figura 6a) foram incorporados a meio BDA para que a concentração final no meio fosse de 200 e 50 $\mu \mathrm{g} / \mathrm{mL}$ em equivalente de glucose, respectivamente. Os números representam a média de 7 repetições seguidos por \pm 0 erro padrão da média. Não houve diferença significativa entre os tratamentos pelo teste $\mathrm{F}$ a $5 \%$ de probabilidade. CV $=6,14 \%$.

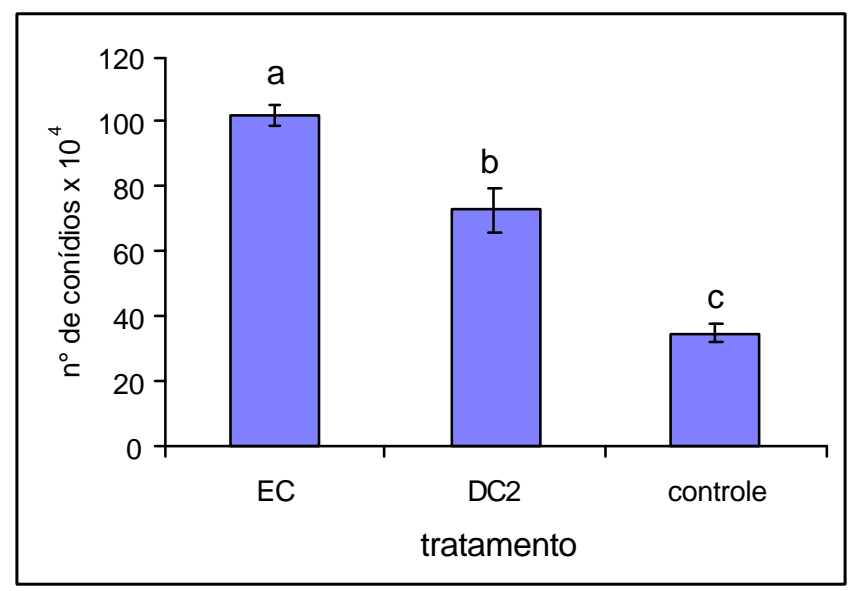

Figura 16 - Efeito do extrato bruto (EC) e da fração DC2 (Figura 6a) da Saccharomyces cerevisiae, na esporulação de Colletotrichum lagenarium. As frações EC e DC2 foram incorporadas a meio de cultura de modo a que a concentração no meio fosse de 200 e $50 \mu \mathrm{g} / \mathrm{mL}$ em equivalentes de glucose. Letras distintas acima das barras representam diferença significativa entre tratamentos pelo teste $\mathrm{F}$ a $5 \%$ de probabilidade. Cada barra representa a média de 5 repetições. CV $=16,4 \%$. 


\subsection{Caracterização espectrofotometrica / espectrometrica dos elicitores}

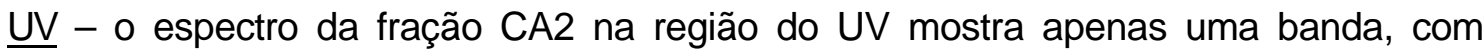
máximo de absorção a 200 nm (Figura 17).

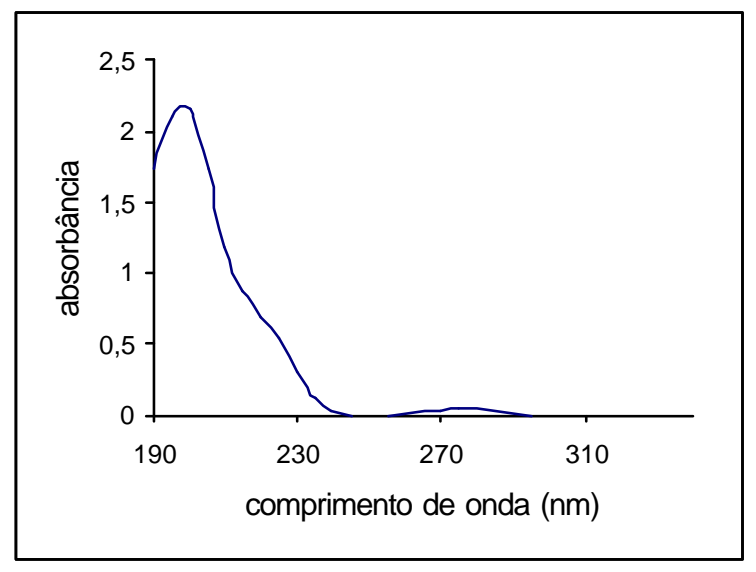

Figura 17 - Espectro na região do ultravioleta da fração de Saccharomyces cerevisiae ligada a Con-A (CA2).

$\underline{\mathbb{R}}$ - foram detectadas as seguintes bandas, na região estudada, da fração CA2 (Figura 18a):

$3387,79 \mathrm{~cm}^{-1}$ - característica de deformação axial N-H (amida)

2932,76 $\mathrm{cm}^{-1}$ - característica de deformação axial C-H alifático

1654,96 cm $\mathrm{cm}^{-1}$ - característica de deformação axial $\mathrm{C}=\mathrm{O}$, banda de amida característica de deformação angular $\mathrm{N}-\mathrm{H}$, banda de amida (sobreposta)

$1454,95 \mathrm{~cm}^{-1}$ - característica de deformação axial C-N

$1057,44 \mathrm{~cm}^{-1}$ - característica de deformação axial C-H alifático

$679,27 \mathrm{~cm}^{-1}$ - banda larga, característica de deformação angular, fora do plano, $\mathrm{N}-\mathrm{H}$

A banda em $3387,79 \mathrm{~cm}^{-1}$ pode ser também uma sobreposição de banda de $\mathrm{N}-\mathrm{H}$ com banda de $\mathrm{O}-\mathrm{H}$. 
No espectro de IR da fração CA1 (Figura 18b), foram detectadas bandas inexistentes no espectro da fração CA2 e algumas bandas semelhantes as do espectro da fração CA2. É provável que as bandas não detectadas no espectro da fração CA2 e detectadas no espectro de $\mathrm{CA} 1$ sejam relativas àpresença de proteínas. $\mathrm{A}$ banda forte e larga a $3387,79 \mathrm{~cm}^{-1}$ característica de amida, estava presente no espectro de CA1, mas com intensidade e largura menor, podendo ser devido à presença de $-\mathrm{OH}$, nos açúcares.
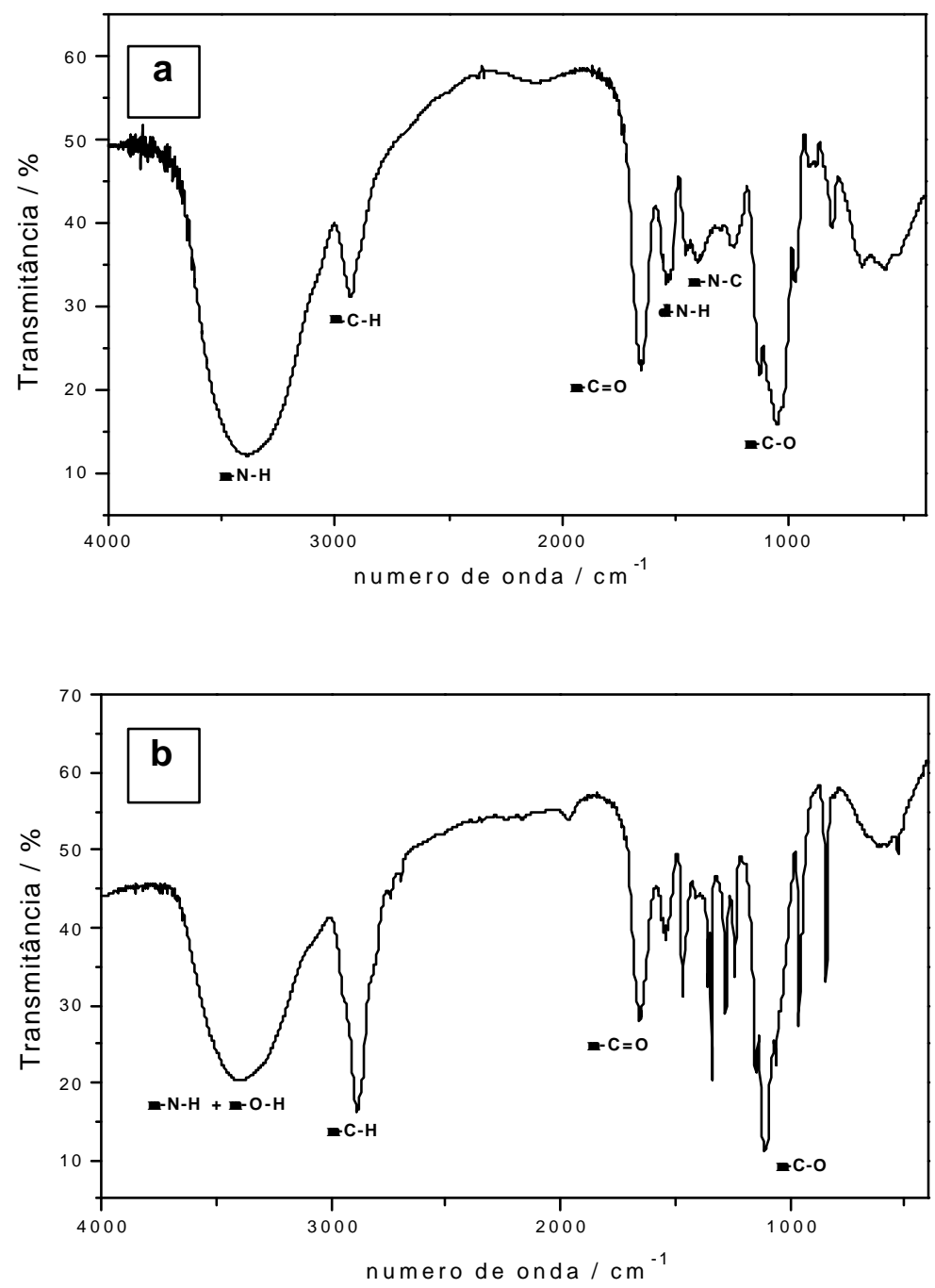

Figura 18 - Espectro na região do infravermelho de frações da Saccharomycees cerevisiae. (a). Fração ligada a Con-A (CA2); (b). fração não ligada a Con-A (CA1). 
$\underline{\mathrm{RMN}}$ - o espectro da fração CA2 apresenta sinais em $\delta=100,78,72,70,66$ e 62 ppm. O sinal em $\delta 96 \mathrm{ppm}$ é da referência interna $\left(\mathrm{CCl}_{4}\right)$ (Figura 19), provavelmente dos carbonos 1, 3, 2, 4, 5 e 6 (Apêndice 3), presentes em manose ou glucose, respectivamente (Kóllar et al., 1997).

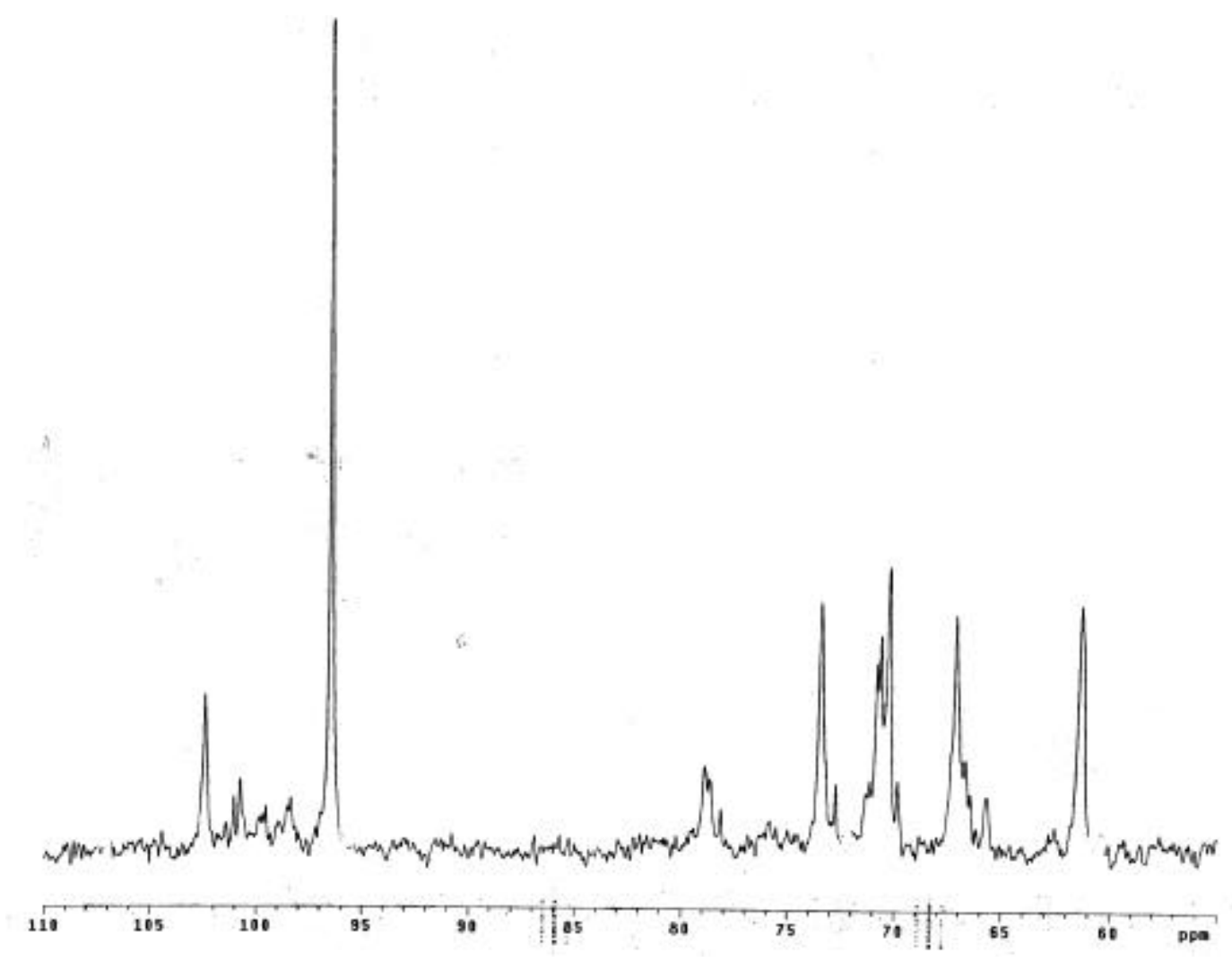

Figura 19 - Espectro de ressonância magnético nuclear da fração da Saccharomyces cerevisiae ligada a Con-A. 


\section{DISCUSSÃO}

A hipótese de haver um elicitor na parede de Saccharomyces cerevisiae, capaz de induzir resistência em soja e pepino contra infecções fúngicas, foi baseada nos seguintes fatos: (1). capacidade de suspensões de células da levedura de proteger diversas plantas contra infecção (Pascholati, 1998); (2). a presença, na parede da levedura, de elicitores de síntese de fitoalexinas, tanto em soja quanto em sorgo (Hahn \& Albersheim, 1978; Wulff \& Pascholati, 1999); (3). indução de resistência em plantas de tomate contra Fusarium oxysporum f.sp. radicis-lycopersicipor glucanas extraídas da parede da levedura (Behnamou \& Lafontaine, 1995); (4). ocorrência de explosão oxidativa em tecido de pepino tratado com glucana extraída da parede de Phytophthora megasperma (Svalheim \& Robertsen, 1993); (5). semelhança, tanto estrutural como em poder elicitor, de carboidratos estruturais de $S$. cerevisiae e $P$. megasperma (Hahn \& Albershein, 1978) e (6). capacidade de preparados de $S$. cerevisiae de induzir alterações qualitativas e quantitativas na expressão de peroxidases, em sorgo e milho (Roncato \& Pascholati, 1998).

\subsection{Métodos para extração dos elicitores}

Diversos métodos podem ser utilizados para a extração de elicitores da parede de microrganismos. A simples solubilização em água foi eficiente para extrair um elicitor de esporos de Blumeria graminis f.sp. tritici (Schweizer et al., 2000). Em outras situações, uma condição menos suave, como autoclavagem, pode ser necessária (Guzzo, 1989; Jorrin \& Dixon, 1990). Wulff \& Pascholati (1999) utilizaram a autoclavagem, com sucesso, para extrair elicitores da parede de S. cerevisiae. Já Hahn \& Albersheim (1978) fizeram uso de um extrato autolizado da mesma levedura 
para purificação de um elicitor. A autoclavagem permite a extração de mananas da parede da levedura, sendo que as glucanas e a quitina são mais resistentes àextração (Cabib et al., 1982). O método usado por Wulff \& Pascholati (1999), foi escolhido por ser mais simples e, pelos resultados, teve sua eficácia comprovada.

As etapas de purificação como a precipitação etanólica e a separação por cromatografia de troca iônica e de afinidade são freqüentemente utilizadas na purificação de elicitores (Andreu et al., 1998; Davis et al., 1998; Guzzo, 1989; Hahn \& Albersheim, 1978; Koch et al., 1998; Schaffrath et al., 1995; Séjalon-Delmas et al., 1997; Slováková et al., 2000; Wulff \& Pascholati, 1999). A primeira etapa da purificação, a precipitação etanólica, foi capaz de separar uma fração ativa $(E C)$, tanto em cotilédones de soja como em plantas e plântulas de pepino, de uma fração inativa ou menos ativa $(\mathrm{RC})$. A subseqüente separação desta fração, em novas frações, por cromatografia de troca iônica, também levou ao isolamento parcial de compostos mais ativos. A última etapa de fracionamento da amostra, a cromatografia de afinidade, levou à separação da amostra DC1A em duas amostras, ambas com capacidade de induzir resistência em pepino. Assim sendo, o método de purificação utilizado se mostrou válido.

Embora as duas amostras resultantes da separação por cromatografia de afinidade tenham o mesmo poder elicitor, estas apresentam composição diferente. A fração CA1 apresenta tanto carboidratos como proteínas, já a fração CA2 só apresenta carboidratos.

Os preparados elicitores utilizados na indução de resistência, tanto em plantas como em plântulas de pepino, foram uniformizados tento como base a concentração de carboidratos das amostras. A escolha de carboidratos e não de proteínas foi baseada nos fatos 4 e 5 descritos no primeiro parágrafo deste tópico. A redução na severidade de antracnose em plântulas tratadas com a fração CA2 (que só apresentava carboidratos em sua composição) mostrou que existe um carboidrato na parede da levedura capaz de induzir resistência em pepino contra $C$. lagenarium.

Os resultados do trabalho em questão mostram que existem elicitores capazes de induzir resistência em pepino contra $C$. lagenarium e capazes de induzir síntese de gliceolinas em cotilédones de soja. No entanto, em nenhum dos testes conduzidos com diversos preparados (de maior ou menor grau de purificação) foi verificada a indução de resistência em soja contra $M$. diffusa. 


\subsection{Indução de resistência em pepino}

As plântulas de pepino tratadas com o preparado EC, as frações DC1A (fração não adsorvida da cromatografia de troca iônica), CA1 e CA2 (fração não ligada e ligada da cromatografia de afinidade) apresentaram manifestação reduzida de antracnose em relação ao controle.

A utilização de plântulas de pepino permitiu que os ensaios fossem realizados de modo rápido, com um número razoável de repetições e com gasto mínimo de amostras elicitoras. Diversos trabalhos vêm sendo relatados na literatura em que plantas de pepino são substituídas por plântulas, sendo o tratamento elicitor efetuado em cotilédones ou hipocótilos (Siegrist et al.; 1994; Slováková et al., 2000; Sticher \& Métraux, 2000; Svalheim \& Robertsen, 1993). O tratamento com ASM leva ao estabelecimento de indução de resistência tanto em plântulas como em plantas adultas com completa supressão da doença 5-7 dias após a inoculação. Além disto, o preparado EC foi capaz de induzir resistência tanto em cotilédones de plântulas como em folhas de plantas adultas. A capacidade de cotilédones em expressar resistência, após tratamento indutor, permitiu a substituição de plantas adultas por plântulas, para os testes de indução de resistência com as frações das cromatografias. O baixo rendimento do processo de purificação (Anexo) foi o fator decisivo que levou àescolha de cotilédones para a realização dos ensaios de indução de resistência.

O baixo rendimento obtido nas purificações de elicitores é apontado como fator que restringe o estudo de respostas de defesa ou de sinalização (Hahn, 1996). Devido ao baixo rendimento, a maior parte dos trabalhos realizados envolvendo a purificação de elicitores usa respostas de defesa, como acúmulo de fitoalexinas em tecidos vegetais, para nortear a purificação (Davis et al., 1998; Guzzo, 1989; Hahn \& Albersheim, 1978; Wulff \& Pascholati, 1999). Neste trabalho, ao invés do uso de um "marcador de resistência", a severidade da antracnose foi usada como parâmetro na tentativa de purificação de um elicitor da parede de S. cerevisiae.

Como foi já comentado anteriormente, não houve indução de resistência pelo tratamento de plantas ou plântulas de pepino com os preparados SS, SSA nem RC. Os extratos brutos resultantes da extração de elicitores de parede fúngica apresentam composição bastante variável, podendo ter presente mais de um elicitor ou mesmo supressores de respostas de defesa (Fauth et al., 1996; Davis et al., 
1998; Schaffrath et al., 1995; Shiraishi et al., 1997; Wulff, 1997). É possível que nos preparados SS e SSA a concentração dos elicitores fosse muito baixa ou ainda que a ação de outras moléculas, supressoras ou sem atividade, estivessem interferindo com a atividade do elicitor. A adição de etanol ao preparado SSA gerou as frações RC (precipitado) e EC (sobrenadante), a primeira com menor capacidade elicitora que a segunda. A precipitação etanólica possivelmente separou moléculas interferentes e permitiu a obtenção de uma fração que, depois de dialisada e concentrada, apresentou capacidade de induzir resistência em pepino contra $C$. lagenarium.

O preparado EC foi fracionado com o uso de cromatografia de troca iônica e de afinidade. Como era de se esperar, a fração ativa da cromatografia de troca iônica (DC1A) levou a maior nível de proteção que o obtido com o preparado EC. Quanto mais puro o elicitor, maior sua atividade (Davis et al., 1998; Guzzo, 1989). O fato surpreendente foi que as duas frações obtidas na cromatografia de afinidade (CA1 e CA2) levaram à mesma redução, da severidade da antracnose. Além disso, a redução na severidade da doença foi inferior aquela obtida com o uso da DC1A. Possivelmente a fração DC1A era composta por mais de um elicitor com atividade sinérgica. Aceitando a suposição de que existe mais de um elicitor na fração DC1A, a cromatografia de afinidade simplesmente separou os elicitores que se ligam à Con- $A$ daqueles que não se ligam àresina. Embora a redução na severidade da antracnose, apresentada pelas frações CA1 e CA2, fosse menor que aquela apresentada pela fração DC1A, cabe lembrar que a concentração (em termos de carboidratos) usada no tratamento com as frações CA1 e CA2 foi a metade daquela usada na fração DC1A.

É muito provável que o grau de inibição da manifestação da doença seja maior com doses maiores do elicitor. Infelizmente, não é possível calcular uma atividade específica, pois não se sabe se a redução da severidade da doença se comporta linearmente com o aumento da dose do elicitor, como acontece com as fitoalexinas (Figura 14) (Guzzo; 1989; Wulff \& Pascholati, 1999).

O baixo rendimento da purificação e o fato de pelo menos uma molécula elicitora ser um carboidrato não são boas características para que um elicitor possa ser utilizado em larga escala. Além disso, embora a redução na severidade da doença tenha sido alta (chegou a cerca de 70\%) o coeficiente de variação também se manteve alto e reduções um pouco menores não seriam estatisticamente significativas. 
Na maior parte dos experimentos realizados, o coeficiente de variação foi bastante alto para as condições utilizadas (condições controladas de temperatura e luz). O material vegetal utilizado nos testes é um híbrido que contém $10 \%$ de polinizador. O fato do material ser um híbrido e de haver mistura com semente de polinizador pode levar a respostas mais variáveis em relação a doença (Hernandez ${ }^{2}$ ). Portanto, para este tipo de pesquisa, seria mais adequado o trabalho com linhagens.

\subsection{Acúmulo de fenóis}

Os resultados dos ensaios realizados com plântulas de pepino submetidas a tratamento com CA2 e posterior inoculação com C. lagenarium não apresentaram alterações consideráveis na concentração de fenóis livres, nem ligados, em relação ao controle.

Segundo Stermer (1995) a indução de resistência não leva a alterações significativas na concentração de fenóis. No entanto, em pepino tratado com Milsana® ou silício, e desafiado com $S$. fuliginea, há alteração importante, quantitativa e qualitativa, na composição dos fenóis glicosilados (conjugados), sem que haja alteração nos fenóis livres (Daayf et al., 1995; Fawe et al., 1998).

Os fenóis podem ocorrer em células vegetais na sua forma livre, na forma ligada àparede celular, ou ainda, conjugado para a formação de ésteres, amidas ou glicosídeos (Figura 2) (Strack, 1997). Os fenóis livres são facilmente extraídos pelo uso de metanol e, os ligados, por uma reação de esterificação com $\mathrm{NaOH}$ (Kofalvi \& Nassuth, 1995). No entanto, a ligação por laço glicosídico é estável æ̀ bases, requerendo hidrólise ácida ou tratamento com $\beta$-glucosidases para liberação da porção fenólica (Hrazdina et al., 1997; Lehninger, 1984).

No trabalho em questão, só foram avaliados os fenóis livres e os ligados à parede celular. Os resultados estão de acordo com aqueles obtidos anteriormente por Daayf et al. (1995) e Fawe et al. (1998). No entanto, estes resultados

2 HERNANDEZ, R. (Associate Director, R\&D; Seminis Vegetable Seeds). Comunicação pessoal, 2002. 
estão em desacordo com aqueles obtidos por Siegrist et al. (1994) que verificaram alterações na concentração de fenóis ligados à parede, em hastes de pepino, tratadas com o indutor de resistência ácido 2,6 dicloroisonicotínico. É provável que o metabolismo dos fenóis tenha sido alterado nas plântulas tratadas com a fração CA2, já que foi verificado aumento na atividade da peroxidase (discutido a seguir). Além disso, é esperado um aumento de lignificação, já que o fortalecimento de parede celular é tido como importante resposta de defesa envolvida na RSA em cucurbitáceas, e a lignina é formada pela polimerização de fenóis.

Aqui foram avaliadas apenas alterações quantitativas de fenóis. No entanto, trabalhos em que é avaliada a participação de fenóis na resposta de defesa mostram que ocorrem alterações qualitativas e quantitativas no perfil dos fenóis (Anwar et al., 1995; Lo et al., 1999).

Com base no que foi discutido nos parágrafos anteriores, é possível levantar as seguintes hipóteses para explicar o fato de não haver alteração na concentração de fenóis em plântulas tratadas com a fração CA2:

(1). Houve alteração qualitativa mas não quantitativa nos fenóis sintetizados pelas plântulas;

(2). Houve uma alteração apenas nos fenóis glicosilados que não foram analisados;

(3). Houve alteração que levou a aumento rápido da concentração de fenóis tanto livres como ligados. No entanto, houve também uma rápida polimerização para formação de lignina e ligação à parede, o que levou à insolubilização, tanto dos fenóis livres como dos ligados.

Para uma melhor compreensão do comportamento dos fenóis e para que se pudesse afirmar que não houve alteração no metabolismo fenólico, seria necessário uma avaliação qualitativa dos fenóis, seja por cromatografia em camada fina (TLC), seja por HPLC. Além disso, seria útil a determinação da concentração dos fenóis conjugados e da lignina. Um exame microscópico, nos moldes daquele realizado por Behnamou \& Garand (2001), poderia ser interessante para se verificar a incorporação de fenóis a parede celular, a aposições e a papilas. 


\subsection{Atividade de peroxidases}

O fungo $C$. lagenarium, após inoculação em plantas de pepino, demora cerca de 24 horas para germinar e formar o apressório. Quarenta e oito horas após a inoculação a hifa de penetração invade a parede celular (Stein et al., 1993). O simples crescimento na superfície foliar de um mutante de $C$. lagenarium, incapaz de produzir melanina (e por isso com problemas de penetração), já é capaz de estimular a planta a exibir respostas de defesa (Kästner et al., 1998). Do mesmo modo, o crescimento na superfície de raízes de ervilha de um fungo endofítico é capaz de induzir a mesma gama de respostas de defesa (Benhamou \& Garand, 2001). Tendo isto, em mente é de se esperar que as respostas de defesa começem a ocorrer antes da penetração da hifa, ou seja, antes de $48 \mathrm{~h}$.

Embora Roncato \& Pascholati (1998) tenham verificado aumento na atividade de peroxidases e alteração da composição isoenzimática dessas enzimas em plantas de sorgo tratadas com preparados de $S$. cerevisiae, diversos trabalhos, como já comentado anteriormente, vêm demonstrando que o tratamento elicitor em plantas suscetíveis não é suficiente para ativar as respostas de defesa, mas deixa a planta em estado de alerta. A ameaça de infecção é necessária para que ocorram as respostas de defesa (Behnamou \& Lafontaine, 1995; Daayf et al., 1995; Kästner et al., 1998; Schaffrath et al., 1995; Siegrist et al., 1994). O acúmulo de fenóis e/ou fitoalexinas e o aumento da atividade de enzimas relacionadas àdefesa, entre outros mecanismos de defesa, só ocorrem após o contato com o fungo.

Com base no que foi exposto nos dois últimos parágrafos, era esperado que houvesse diferença significativa na atividade das peroxidases no período entre 24 e 48h após a inoculação. Nos experimentos realizados com plântulas de pepino, tratadas com a fração CA2, não houve diferença significativa da atividade de peroxidases entre o controle e as plantas tratadas até $24 \mathrm{~h}$ após a inoculação. No entanto, $48 \mathrm{~h}$ após a inoculação, a diferença foi significativa, perdurando até $96 \mathrm{~h}$ após a inoculação, como esperado.

Entre os papéis atribuídos as peroxidases estão a catálise da formação de lignina (Strack, 1997) e a incorporação de glicoproteínas ricas em hidroxiprolina, por ligações cruzadas, à parede celular (Tenhaken et al., 1995). Ambas as funções levam ao enrijecimento da parede vegetal, o que dificulta a penetração de 
um patógeno. A indução de resistência em pepino é ligada ao insucesso do fungo em penetrar a parede celular (Fauth et al., 1996) e, portanto, deve estar ligada ao fortalecimento da parede celular e àatividade de peroxidases (Stein et al., 1993).

Embora a participação de peroxidases no estabelecimento de indução de resistência seja, pelo menos em pepino, considerada como importante, alguns trabalhos mostram que o aumento da atividade da enzima não esta relacionado com o estabelecimento de uma relação incompatível. Nesses casos, o aumento da atividade de peroxidases é considerado como sendo apenas uma resposta da planta àinfecção (Ray \& Hammerschmidt, 1998; Siegrist et al., 1994).

O aumento da atividade de peroxidases verificado nas plantas tratadas com CA2 e inoculadas com o patógeno não foi acompanhado de aumento na concentração de fenóis, como era inicialmente esperado, já que os fenóis servem como substrato para a enzima. No entanto, outros trabalhos verificaram que o aumento da atividade de peroxidases não implica, necessariamente, em aumento na concentração de fenóis ou aumento na lignificação. Hipocótilos de pepino com resistência induzida por ácido 2,6 dicloroisonicotínico apresentam acúmulo de fenóis e de lignina, sem apresentar aumento significativo na atividade de peroxidases (Siegrist et al., 1994). Plantas de trigo infectadas por WSMV têm aumento na atividade da FAL, de peroxidase, acúmulo de fenóis livres e ligados, mas não têm aumento na lignificação (Kofalfi \& Nassuth, 1995). Plantas de batata transformadas com o gene de uma peroxidase de pepino apresentam alta atividade da enzima. No entanto, esse aumento não é seguido por aumento de lignificação nem por aumento na resistência contra patógenos fúngicos e bacterianos (Ray et al., 1998).

O metabolismo vegetal é bastante complexo, não sendo possível, na maior parte dos casos, estabelecer ligação direta entre aumento de atividade de determinada enzima e aumento na síntese de seus substratos. A presença de fenóis livres estimula a atividade de peroxidases (Grisebach, 1981). É possível que o tratamento elicitor utilizado e a posterior infecção levem à descompartimentalização de fenóis (glicosilados ou não). Esses fenóis, por sua vez, podem estimular a atividade da peroxidase, levando à formação de lignina e à síntese de novos fenóis que, rapidamente, seriam polimerizados. Ou ainda, é possível uma alteração na proporção normal de fenóis produzidos na via dos fenilpropanóides, sendo que a síntese dos alcoóis cinâmicos (precursores da lignina) tenham sido favorecida e a síntese de outros 
fenóis tenha sido prejudicada. Estas hipóteses poderiam ser confirmadas por análise de lignina e uma análise qualitativa de fenóis, como já mencionado no item anterior.

A localização das diversas isoformas da peroxidase é relacionada com sua função. Peroxidases ligadas ao enrijecimento de parede e à formação de $\mathrm{H}_{2} \mathrm{O}_{2}$ estão ligadas à parede celular (Grisebach, 1981; Strack, 1997). A solubilização destas enzimas é mais fácil quando se faz uso de um tampão salino, como o PBS (tampão fosfato salino) (Ray \& Hammerschmidt, 1998; Kofalfi \& Nassuth, 1995). No presente trabalho, a extração de peroxidases foi realizada na presença de tampão fosfato sem adição de sais, conforme descrito por Dalisay \& Kuc (1995a). A adição de sais ao tampão de extração poderia levar a resultados diferentes.

\subsection{Testes de fungitoxidez in vitro}

A incorporação da fração EC e da fração DC2A a meio de cultura (BDA) não levou àalteração na velocidade de crescimento micelial de $C$. lagenarium, mas levou ao aumento acentuado na esporulação. O aumento na esporulação não é um fato estranho já que se faz incorporação de extratos de levedura a diversos meios de cultura.

O fato de nenhuma das amostras testadas interferir com o crescimento micelial do fungo é um indício de que nenhum dos compostos extraídos da levedura é fungitóxico. No entanto, este fato não descarta a possibilidade de algum dos compostos ser metabolizado pela célula vegetal e transformado em uma substância fungitóxica, o que não foi avaliado neste trabalho.

A possibilidade do uso de um indutor de resistência extraído de $S$.

cerevisiae em larga escala deve ser avaliada levando em conta o aumento da esporulação do fungo em questão. Se por um lado o produto é capaz de reduzir a severidade da doença, por outro, o mesmo produto pode levar a aumento na produção de inóculo secundário e, conseqüentemente, aumento no número de ciclos do patógeno. Isto poderia fazer com que houvesse um incremento de severidade na avaliação a longo prazo.

Os resultados obtidos neste trabalho indicam que plântulas de pepino tratadas com a fração CA2 são mais resistentes à antracnose que plantas não 
tratadas. Este aumento na resistência é acompanhado pelo aumento na atividade de peroxidases, sem que haja alteração na concentração de fenóis livres ou ligados. A fração EC não interferiu com o crescimento micelial de $C$. lagenarium. Estes resultados indicam que houve uma alteração no metabolismo vegetal que levou à contenção, parcial, do desenvolvimento do fungo. Com base nestes fatos é bastante provável que a fração CA2 tenha capacidade de induzir resistência em pepino.

\subsection{Indução de resistência e de fitoalexinas em soja}

A presença de carboidratos na parede celular de $S$. cerevisiae, capazes de induzir cotilédones de soja a produzir gliceolinas, não é fato novo (Hahn \& Albersheim, 1978). As fitoalexinas são conhecidos compostos antimicrobianos que fazem parte do arsenal de defesa da planta. A importância dessa classe de compostos para o estabelecimento da resistência induzida ainda não foi completamente determinada e a questão "As fitoalexinas são parte da resposta de defesa ou são apenas consequência de uma infecção ?" continua até hoje sem resposta (Hammerschmidt, 1999b). Se por um lado existem dúvidas da importância das fitoalexinas, por outro, foi demonstrado que na relação incompatível soja $\times P$. megasperma f.sp. sojae, a síntese de gliceolinas é mais importante do que outras respostas de defesa, como o acúmulo de outros fenóis ou mesmo a lignificação (Mohr \& Cahill, 2001).

Em soja, as gliceolinas são sintetizadas a partir de precursores glicosilados. Quando o tecido vegetal é atacado por um patógeno, ou tratado com elicitor, os precursores sofrem alterações em suas moléculas, originando as fitoalexinas. O aumento na concentração de fitoalexinas ocorre em células bem próximas ao ponto de penetração. Já nas células mais distantes, ocorre um aumento na síntese dos precursores e essas ficam em estado de alerta (Graham, 1995).

No trabalho aqui apresentado, o tratamento de cotilédones de soja com frações de maior ou menor grau de purificação, extraídas da parede celular de $S$. cerevisiae, levou a acúmulo significativo de gliceolinas. No entanto, nenhum desses preparados foi capaz de induzir resistência em plantas adultas de soja contra $M$. diffusa. 
O não estabelecimento da RSA pode ser explicado pelas seguintes hipóteses: (1). a dose do elicitor ser insuficiente; (2). presença de supressores nos extratos testados; (3). tempo inadequado entre a indução e a inoculação; (4). as respostas de defesa estimuladas pelos tratamentos podem não ter sido efetivas contra o patógeno em questão; (5). O patógeno ser tolerante a gliceolinas e (6). a síntese das fitoalexinas seguir uma rota de sinalização diferente da rota de sinalização de outras respostas de defesa, sem as quais o estabelecimento da RSA ficaria prejudicado.

Resultados de diversas pesquisas mostram que a expressão de respostas de defesa é relacionada à dose do elicitor, sendo que, na maior parte dos casos, o aumento da dose provoca respostas mais intensas (Koch et al., 1998; Schaffrath et al., 1995; Slováková et al., 2000). Nos experimentos de indução de fitoalexinas, doses crescentes da fração EC levaram a maior acúmulo de gliceolinas (Figura 14). Nos testes de indução de resistência em soja, três doses foram usadas (100, 200 e $400 \mu \mathrm{g} / \mathrm{mL}$ de equivalentes de glicose). Respostas diferentes daquelas verificadas, e talvez até indução de resistência, poderiam ter sido obtidas com outras doses.

Além do fator dose, outro fator que pode interferir com a manifestação de resistência induzida é a presença de supressores. Wulff (1997), trabalhando com o mesmo tipo de elicitores extraídos da levedura, verificou que, além da presença de um forte elicitor de síntese de fitoalexinas em sorgo, havia também, presente no extrato bruto (equivalente ao preparado EC), uma fração capaz de suprimir completamente a síntese de fitoalexinas. A possível presença de um supressor nos preparados testados pode explicar a falha na indução de resistência em soja contra o fungo causador de oídio.

O acúmulo de fitoalexinas pode ser verificado tanto em relações compatíveis como em relações incompatíveis (Lo et al., 1999; Mohr \& Cahill, 2001), havendo portanto necessidade de outras respostas de defesa e/ou diferenças na cinética de síntese das fitoalexinas para o estabelecimento de resistência. Como já comentado anteriormente, é possível haver mais de uma rota de sinalização. Essas rotas podem ser ativadas por compostos diferentes e levar, de modo independente, a diferentes respostas de defesa (Koch et al., 1998). Uma glicoproteína purificada a partir do filtrado de cultura do fungo Verticillium dahliae é capaz de induzir a síntese de fitoalexinas em células de algodão, mas incapaz de ativar a explosão oxidativa. Em 
contraste, o preparado não purificado é capaz de produzir as duas respostas de defesa (Davis et al., 1998). Com base nesses dados, é plausível supor, que nos extratos de $S$. cereviseae avaliados, exista um elicitor capaz de induzir a síntese de fitoalexinas em cotilédones de soja, mas incapaz de induzir outras respostas importantes de defesa, como a HR e a explosão oxidativa, sem as quais não foi possível o estabelecimento da resistência induzida.

O fato de os extratos testados não induzirem resistência em soja contra $M$. diffusae não significa, necessariamente, que estes não sejam capazes de induzir resistência contra outros patógenos. Diversos patógenos apresentam resistência a fitoalexinas produzidas por seus hospedeiros. A capacidade de detoxificação de fitoalexinas, em determinadas relações compatíveis, é um fator de virulência importante para o patógeno (Vanetten et al., 2001). A presença de um mecanismo de detoxificação de gliceolinas em $M$. diffusae poderia explicar os resultados obtidos.

Cabe salientar que as interações planta-patógeno, no caso do oídio (biotrófico), são bem diferentes daquelas que ocorrem em interações com fungos hemibiotróficos ou necrotróficos. Trabalhos têm mostrado que, no caso de oídios, o acúmulo de fenóis ou de fitoalexinas tem papel importante na resposta de defesa (Daayf et al., 1995; Kunoh, 1995; Wurms et al., 1999). No entanto, o simples tratamento com um indutor não é capaz de levar ao acúmulo desses compostos (Daayf, 1995; Fawe et al., 1998). O tratamento elicitor leva à planta a um estado de competência ("primming") e torna a resposta de defesa mais rápida e intensa no momento em que ocorre o contato com o patógeno (Conrath et al., 2001). O tratamento de cotilédones de soja com elicitores faz com que haja a síntese de fitoalexinas, sem a necessidade de contato com um patógeno. Segundo Fauth et al. (1996), o ferimento causado nesse tipo de bioensaio é suficiente para condicionar os tecidos cotiledonares, e o tratamento subseqüente com o indutor faz o papel do patógeno, levando à síntese de compostos de defesa. Sendo assim, a indução de fitoalexinas em cotilédones de soja, por tratamento elicitor, não garante que plantas tratadas com o mesmo elicitor vão sintetizar fitoalexinas quanto ameaçadas de infecção. A síntese dependerá, além do elicitor, da capacidade do patógeno em estimular al ativar os mecanismos de defesa que estariam em estado de alerta. 
O ASM é um potente indutor de resistência em pepino contra $C$. lagenarium, mas é incapaz de induzir resistência no mesmo hospedeiro contra Sphaerotheca fuliginea (Wurms et al., 1999). É possível que os compostos de defesa induzidos pelo tratamento da soja com os elicitores testados não sejam suficientes, em qualidade ou quantidade, para impedir a manifestação de oídio, mas sejam suficientes para o controle de um outro patógeno, como no caso do ASM em pepino.

Como visto anteriormente, diversas hipóteses podem explicar 0 fracasso da indução de resistência em soja contra $M$. diffusa. A realização de novas pesquisas com o patossistema soja - $M$. diffusa poderiam auxiliar na compreensão dos resultados. Uma primeira etapa seria a realização da inoculação alguns dias mais tarde do que o realizado. Se mesmo assim os resultados verificados fossem idênticos aos anteriores, seria interessante verificar se plantas adultas de soja sintetizam fitoalexinas em resposta ao tratamento elicitor e à inoculação. Caso a resposta fosse negativa, poderia ser realizada dosagem de $\mathrm{H}_{2} \mathrm{O}_{2}$ e de enzimas hidrolíticas em cotilédones de soja tratados com os elicitores. Assim, seria possível verificar se a síntese de fitoalexinas é a única resposta de defesa apresentada pelos cotilédones.

\subsection{Caracterização espectrofotometrica/ espectrometrica dos elicitores}

O espectro na região do infravermelho (IR) da fração CA2 apresentou bandas características de amida, semelhantes às de quitina e de quitosana (Monteiro Júnior, 1999), o que leva a crer que exista pelo menos um polímero ou oligômero que contenha $N$-acetilglucosamina ou glucosamina. Não foi observada nenhuma banda característica de aminoácidos (Paiva et al., 1996; Silverstein et al., 1979).

O espectro na região do ultravioleta (UV) da fração CA2 não apresenta nenhuma banda a $280 \mathrm{~nm}$. A absorção a $280 \mathrm{~nm}$ é característica dos aminoácidos aromáticos tirosina e triptofano (a fenilalanina tem máximo a $260 \mathrm{~nm}$ ) e é utilizada para detecção de proteínas (Lehninger, 1984). Há uma banda forte de absorção em 205 nm, que pode ser atribuída àdiversos compostos.

Os dados do IR e do UV confirmam a ausência de proteínas na fração CA2 e levantam a hipótese do composto ter $N$-acetilglucosamina ou glucosamina em sua molécula. Com certeza, o composto não é a quitosana, já que a quitosana é 
altamente insolúvel em água e o composto em questão é hidrofílico. Além disso, a quitosana é um derivado da quitina e esta é de difícil extração (Cabib et al., 1982).

Com base nestes dados e considerando que: (1). apenas mananas foram extraídas pela autoclavagem; (2). os compostos presentes na fração CA2 não foram adsorvidos pela resina DEAE-Celulose e, por isso, não devem ter carga; (3). não existe proteína na fração CA2 e (4). o fósforo confere carga ao polímero (Cabib et al., 1982), é possível que as mananas tenham sido clivadas nos pontos indicados pelas setas grossas da Figura 20. Assim sendo, na fração CA2 podem estar presentes mananas, com diversos pesos moleculares, ligadas à $\mathrm{N}$-acetilglucosamina (ou a glucosamina) sem a presença de fósforo ou aminoácidos.

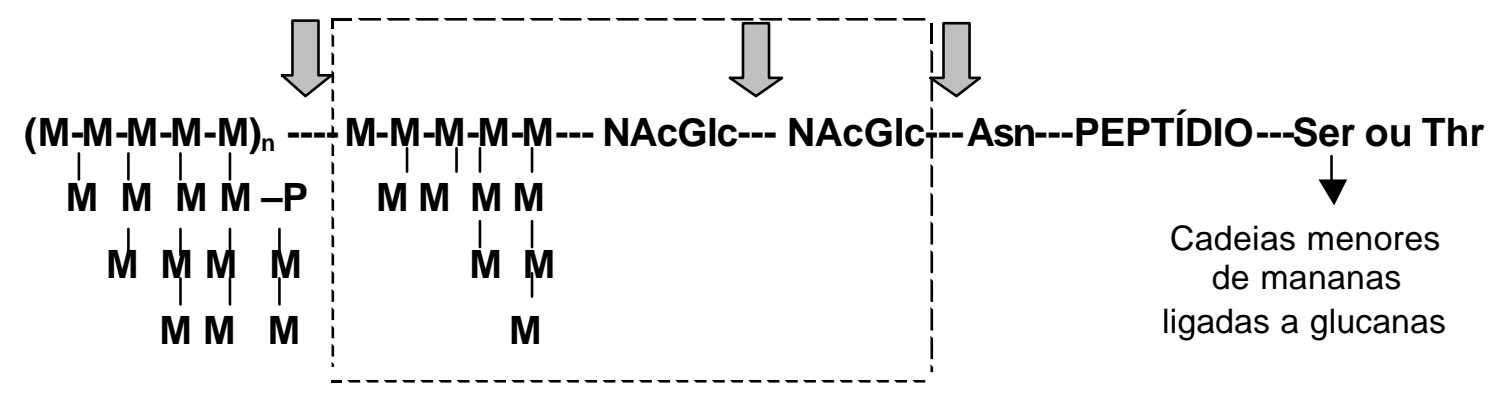

Figura 20 - Molécula hipotética possivelmente presente na fração CA2 (dentro do retângulo tracejado). As setas grossas indicam os locais de provável quebra da manoproteína para formação de um oligômero presente na fração CA2. $\mathrm{M}=$ manose $; \mathrm{P}=$ fósforo; $\mathrm{NAcGlc}=\mathrm{N}$-acetilglucosamina; Asn = asparagina; Ser $=$ serina; Thr $=$ treonina .

A presença de glucanas não pode ser completamente descartada. Segundo Cabib et al. (1982), as glucanas são extraídas por tratamento com alcali e ácido a quente. No entanto, não é impossível que alguma porção do polissacarídeo tenha sido extraída junto com as mananas.

O fracionamento dos polissacarídeos da parede celular de $S$. cerevisiae leva a frações que, quando separadas por cromatografia de afinidade (ConA), geram duas novas frações, uma com afinidade pela Con-A e outra sem afinidade 
pela resina. A diferença entre duas frações é a presença na primeira de mananas e ausência destas na fração sem afinidade, formada apenas por glucanas (Kollár et al., 1997).

A lecitina Con-A tem afinidade por $\alpha$-D-manopiranosídeos, $\alpha$-Dglucopiranosídeos e resíduos com conformação espacial semelhante. Para que haja ligação dos açúcares a resina, é necessário que as hidroxilas dos carbonos 3 , 4 e 5 estejam livres (Pharmacia, 1991). Nas mananas, a maior parte das ligações na cadeia ocorre entre os carbonos 1 e 6 . Já nas glucanas, a maior parte das ligações é entre carbonos 1 e 3 (Lipke \& Ovalle, 1998). Assim sendo, é de se esperar que as $\beta-1,6$ mananas se liguem a Con- $A$, e as $\beta-1,3$ glucanas, não. Portanto, é possível que na fração CA1 existam glucanas em ligação $\beta-1,3$ ou mananas com algumas das hidroxilas das posições 3,4 ou 5 bloqueadas (Apêndice 3 ).

$\mathrm{O}$ RMN de ${ }^{13} \mathrm{C}$ obtido da fração CA2 guarda grande semelhança com aquele obtido de uma fração da parede de $S$. cerevisiae, formada por glucanas (Kollár et al., 1997). O espectro de RMN, tanto para glucose como para manose é idêntico. Os carbonos sofrem os mesmos deslocamentos devido à localização das hidroxilas e carbonila nas mesmas posições. 


\section{CONCLUSÕES}

(1). A levedura Saccharomyces cerevisiae possui em sua parede elicitores que podem ser extraídos por autoclavagem.

(2). Estes elicitores foram capazes de induzir a síntese de fitoalexinas em cotilédones de soja, mas incapazes de induzir resistência em plantas adultas de soja contra o fungo causador de oídio (Microsphaera diffusa).

(3). Existem pelo menos dois elicitores, não fungitóxicos, capazes de induzir resistência em pepino contra Colletotrichum lagenarium e aumentar a atividade de peroxidases. Um destes elicitores é provavelmente uma manana ligada a pelo menos uma molécula de $\mathrm{N}$-acetilglucosamina ou àglucosamina.

(4). O baixo rendimento do processo de purificação e o fato dos elicitores estimularem a esporulação de $C$. lagenarium tornam difícil sua utilização em larga escala. 
ANEXO 
Rendimento das etapas de purificação dos elicitores extraídos da parede celular da Saccharomyces cerevisiae, em termos de proteínas e carboidratos.

\begin{tabular}{|c|c|c|}
\hline Etapa & Proteínas(\%) & Carboidratos (\%) \\
\hline Precipitação etanólica & 30,0 & 44,0 \\
\hline $\begin{array}{l}\text { Diálise e concentração (após a } \\
\text { precipitação etanólica) }\end{array}$ & 57,6 & 6,7 \\
\hline Cromatografia de troca iônica & 94,8 & 90,2 \\
\hline $\begin{array}{l}\text { Diálise e concentração (após a } \\
\text { cromatografia de troca iônica) }\end{array}$ & 67,0 & 63,1 \\
\hline Cromatografia de afinidade & 18,6 & 63,9 \\
\hline $\begin{array}{l}\text { Diálise e concentração (após a } \\
\text { cromatografia de troca iônica) }\end{array}$ & 39,2 & 62,97 \\
\hline
\end{tabular}




\section{REFERÊNCIAS BIBLIOGRÁFICAS}

AGRIOS, G.N. Plant pathology. 4 ed. San Diego: Academic Press. 1997. 635p.

ANDREU, A.; TONÓN, C.; VAN DAMME, M.; HUARTE, M.; DALEO, G. Effect of glucans from different races of Phytophthora infestans on defense reactions in potato tuber. European Journal of Plant Pathology, v.104, p. 777-783, 1998.

ANWAR, M. N.; MAJUMDER, S. K.; SHETTY, H. S. Changes in phenolic acids in sorghum and maize leaves infected with Peronosclerospora sorghi. Indian Phytopathology, v.48, n.1, p.21-26, 1995.

BASSE, C.; BOCK, K.; BOLLER, T. Elicitors and supressors of the defense response in tomato cells: purification and characterization of glycopeptide elicitors and glycan supressors generated by enzymatic cleavage of yeast invertase. The Journal of Biological Chemistry, v.267, n.15, 1992.

BARZ, W.; KÖSTER, J. Turn over and degradation of secondry (natural) products. In: CON, E. E.; STUMPF, P. K. (Ed.) The biochemistry of plants: a comprehensive treatise. New York: Academic Press, 1981. v. 7, p. 457-479.

BECKER, J.; KEMPF, R.; JEBLICK, W.; KAUSS, H. Induction of competence for elicitation of defense responses in cucumber hypocotyls requires proteasome activity. The Plant Journal, v. 21, n.3, p. 311-316, 2000. 
BECKMAN, C. H. Phenolic-storing cells: keys to programmed cell death and periderm formation in wilt disease resistance and in general defense responses in plants? Physiological and Molecular Plant Pathology, v. 57, p.101-110, 2000.

BENHAMOU, N.; GARAND, C. Cytological analysis of defense-related mechanisms induced in pea root tissues in response to colonization by nonpathogenic Fusarium oxysporum Fo47. Phytopathology, v.91, n.8, p.730-740, 2001.

BENHAMOU, N.; LAFONTAINE, P. J. Ultrastructural and cytochemical characterization of elicitor-induced structural responses in tomato root tissues infected by Fusarium oxysporum f. sp. radicis-lycopersici. Planta, v.197, p.89-102, 1995.

BERTOZZI, C.; KIESSLING, L. L. Chemical glycobiology. Science, v.291, p.23572364, 2001.

BOSTOCK, R.M. Signal conflicts and synergies in induced resistance to multiple attackers. Physiological and Molecular Plant Pathology, v. 55, n. 2, p. 99-109, 1999.

BOSTOCK, R. M., KARBAN, R., THALER, J. S.; WEYMAN, P. D.; GILCHRIST, D. Signal interactions in induced resistance to pathogens and insect herbivores. European Journal of Plant Pathology, v.107, n.1, p.103-111, 2001.

BRADFORD, M. M. A rapid and sensitive method for the quantitation of microgram quantities of protein utilizing the principle of protein-dye binding. Analytical Biochemistry, v.72, p.248-254, 1976.

CABIB, E.; ROBERTS, S; BOWERS, B. Synthesis of the yeast cell wall and its regulation. Annual Review of Biochemistry, v.51, p.763-793, 1982.

CAMERON, R. K. Salicylic acid and its role in plant defense responses: what do we really know? Physiological and Molecular Plant Pathology, v.56, n.3, p.91-93, 2000. 
CERVONE, F.; HAHN, M. G.; DE LORENZO, G.; DARVILL, A.; ALBERSHEIM, P. Host-pathogen interactions: XXXIII. A plant protein converts a fungal pathogenesis factor into an elicitor of plant defense responses. Plant Physiology, v.90, p.542$548,1989$.

CHAMNONGPOL, S.; WILLEKENS, H.; MOEDER, W.; LANGEBARTELS, C.; SANDERMANN JR, H.; VAN MONTAGU, M.; INZÉ, D., CAMP, W.V. Defense activation and enhanced pathogen tolerance induced by $\mathrm{H}_{2} \mathrm{O}_{2}$ in transgenic tobacco. Proceedings of the National Academy of Science of the United States of America, v.95, p. 5818-5823, 1998.

CHEN, C.; BÉLANGER, R.; BENHAMOU, N.; PAULITZ, T. C. Defense enzymes induced in cucumber roots by treatment with plant growth-promoting rhizobacteria (PGPR) and Pythium aphanidermatum. Physiological and Molecular Plant Pathology, v.56, p.13-23, 2000.

CONRATH, U.; THULKE, O.; SCHWINDLING, S.; KOHLER, A. Primming as a mechanism in induced systemic resistance in plants. European Journal of Plant Pathology, v.107, n.1, p.113-119, 2001.

COSTET, L.; CORDELIER, S.; DOREY, S.; BAILLIEUL, F.; FRITIG, B.; KAUFFMANN, S. Relationship between localized acquired resistance (LAR) and the hypersensitive response (HR): HR is necessary for LAR to occur and salicylic acid is not sufficient to trigger LAR. Molecular Plant-Microbe Interactions, v. 12, n.8, p.655-662, 1999.

COVENTRY, H. S.; DUBERY, I. A. Lipopolyssacharides from Bulkholderia cepacia contribute to an enhance defensive capacity and the induction of pathogenesisrelated proteins in Nicotianae tabacum. Physiological and Molecular Plant Pathology, v. 58, p.149-158, 2001. 
DAAYF, F.; BEL-RHLID, R.; BÉLANGER, R.R. Methyl ester of p-coumaric acid: A phytoalexin-like compound from long english cucumber leaves. Journal of Chemical Ecology, v.23, n.6, p.1517-1526, 1997.

DAAYF, F.; SCHIMITT, A.; BÉLANGER, R. R. The effects of plant extracts of Reynoutria sachalinensis on powdery mildew development and leaf physiology of long english cucumber. Plant Disease, v.79, n.6, p.577-580, 1995.

DALISAY, R. F.; KUC, J. A. Persistence of induced resistance and enhanced peroxidase and chitinase activities in cucumber plants. Physiological and Molecular Plant Pathology, v.47, n.5, p. 315-327, 1995a.

DALISAY, R. F.; KUC, J. A. Persistence of reduced penetration by Colletotricum lagenarium into cucumber leaves with induced systemic resistance and its relation to enhanced peroxidase and chitinase activities. Physiological and Molecular Plant Pathology, v.47, n.5, p. 329-338, 1995b.

DAVIS, D. A.; LOW, P. S.; HEINSTEIN, P. Purification of a glycoprotein elicitor of phytoalexin formation from Verticillium dahliae. Physiological and Molecular Plant Pathology, v.52, p.259-273, 1998.

DEAN, R. A.; KUC, J. Induced systemic protection in cucumber: effects of inoculum density on symptom development caused by Colletotrichum lagenarium in previously infected and uninfected plants. Phytopathology, v. 76, n.2, p. 186-189, 1986.

EDEN BIOSCIENCE. http://www.edenbio.com/ms/msl.html. (17 dec. 2001).

ELLINGBOE, A. H. Plant-pathogen interactions: genetic and comparative analysis. European Journal of Plant Pathology, v.107, n.1, p.79-84, 2001.

EVANS, I. J.; GREENLAND, A. J. Transgenic approaches to disease protection: applications of antifungal proteins. Pesticide Science, v.54, p. 353-359, 1998. 
FARRAR, J. J.; NUNEZ, J. J.; DAVIS, R. M. Influence of soil saturation and temperature on Erwinia chrysantemi soft rot of carrot. Plant Disease, v.84, n.6, p.665-668, 2000.

FAUTH, M.; MERTEN, A.; HAHN, M. G.; JEBLICK, W.; KAUSS, H. Competence for elicitation of $\mathrm{H}_{2} \mathrm{O}_{2}$ in hypocotyls of cucumber is induced by breaching the cuticle and is enhanced by salicylic acid. Plant Physiology, v.110, n.2, p.347-354, 1996.

FAWE, A.; ABOU-ZAID, M.; MENZIES, J. G.; BÉLANGER, R. R. Silicon-mediated accumulation of flavonoid phytoalexins in cucumber. Phytopathology, v. 88, n. 5, p.396-401, 1998.

GODARD, J. F.; ZIADI, S.; MONOT, C.; LE CORRE, D.; SILUÉ, D. Benzothiadizole (BTH) induces resistance in cauliflower (Brassica oleracea var botrytis) to downy mildew of crucifers caused by Peronospora parasitica. Crop Protection, v.18, n.6, p. 397-405, 1999.

GÖRLACH, J.; VOLRATH, S.; KNAUF-BEITER, G.; HENGY, G.; BECKHOVE, U.; KOGEL, K.; OOSTENDORP, M.; STAUB, T.; WARD, E.; KESSMANN,H.; RYALS, $\mathrm{J}$. Benzothiadizole, a novel class of inducers of systemic acquired resistance, activates gene expression and disease resistance in wheat. The Plant Cell, v.8, p.629, 1996.

GOWDA, P. S. B.; BHAT, S. G.; BHAT, S. S. Peroxidase and polyphenol oxidase activities in sorghum and Peronosclerospora sorghi interaction. Current Science, v.58, n.18, p.1037-1039, 1989.

GRAHAM, T. L. Celular Biochemistry of phenylpropanoid responses of soybean to infection by Phytophthota sojae. In: DANIEL, M.; PURKAYASTHA, R. P. (Ed.) Handbook of phytoalexin metabolism and action. New York: Marcel Decker, 1995. p. 85-117. 
GREEnBERG, T. G. Programmed cell death: a way of life for plants. Proceedings of the National Academy of Science of the United States of America, v. 93, p. 12094-12097, 1996.

GRISEBACH, H. Lignins. In: CON, E. E.; STUMPF, P. K. (Ed.) The Biochemistry of plants: a comprehensive treatise. New York: Academic Press, 1981. vol. 7, cap.15, p. $457-479$.

GUZZO, S.D. Elicitação da fitoalexina gliceolina em cotilédones de soja (Glycine max (L.) Merril) por polissacarídeos extracelulares de uredinosporos de Hemileia vastatrix Berr, et Br. Piracicaba, 1989. 152p. Dissertação (Mestrado) - Escola Superior de Agricultura "Luiz de Queiroz", Universidade de São Paulo.

HAGERMAN, A. E.; BUTTLER, L. G. Tannins and lignins. In: ROSENTHAL, G. A.; BRENBAUM, M. R. Herbivores: their interactions with secondary plant metabolites. San Diego: Academic Press, 1991. v.1, cap. 10, p.355-384.

HAHN, M. G. Microbial elicitors and their receptors in plants. Annual Review of Phytopathology, v. 34, p. 387-412, 1996.

HAHN, M. G.; ALBERSHEIM, P. Host-Pathogen Interactions - XIV. Isolation and partial characterization of an elicitor form yeast extract. Plant Physiology, V.62, p.107$111,1978$.

HAHN, M. G.; CHEONG, J. J.; ALBA, R.; ENKERLI, J.; CÔTÉ, F. Oligossacharide elicitors: structure and recognition. In: INTERNATIONAL CONFERENCE OF EUROPEAN FOUNDATION FOR PLANT PATHOLOGY. 2., Strasbourg, 1992. Proceedings. Dordrecht: Kluwer Academic, 1993. p. 99-116.

HAMMERSCHMIDT, R. Induced resistance: how do induced plants stop pathogens ? Physiological and Molecular Plant Pathology, v. 55, p. 77-84, 1999 a. 
HAMMERSCHMIDT, R. Phytoalexins: What have we learned after 60 years ? Annual Review of Phytopathology, v. 37, p. 285-306, 1999b.

HAMMERSCHMIDT, R.; MÉTRAUX, J.P.; VAN LOON, L.C. Inducing resistance: a summary of papers presented at the First International Symposium on Induced Resistance to Plant Diseases, Corfu, May 2000. European Journal of Plant Pathology, v.107, n.1, p.1-6, 2001.

HEATH, M. C. Thoughts on the role and evolution of induced resistance in natural ecosystems, and its relationship to other types of plant defense. In: HAMMERSCHMIDT, R.; KUC, J. (Ed.) Induced resistance to disease in plants. New York: Kluwer Academic, 1995. p. 141-151.

HEATH, M. C. Non-host resistance to plant pathogens: nonspecific defense or the result of specific recognition events? Physiological and Molecular Plant Pathology, v. 58, p. 53-54, 2001 a.

HEATH, M. C. Pathogenicity factors and resistance mechanisms. Physiological and Molecular Plant Pathology, v. 58, p. 147-148, 2001b.

HEIL, M. The ecological concept of costs of induced systemic resistance (ISR). European Journal of Plant Pathology, v.107, n.1, p.137-146, 2001.

HONÉE, G. Engineered resistance against fungal plant pathogens. European Journal of Plant Pathology, v.105, p.319-326, 1999.

HRAZDINA, G. Compartimentation in phenolic metabolism. Acta Horticulturae, v.1, n. 381, p. 86-93, 1994.

HRAZDINA, G.; BOREJSZA-WYSOCKI, W.; LESTER, C. Phytoalexin production in an apple cultivar resistant to Venturia inaequalis. Phytopathology, v. 87, n. 8, p. 868876, 1997. 
HUANG, Q.; KUC, J. Cutin, cutinase and esterase as related to the induced systemic resistance of cucumber against Colletotrichum lagenarium. Physiological and Molecular Plant Pathology, v.46, n.3, p.215-226, 1995.

HUTCHESON, S. W. Current concepts of active defense in plants. Annual Review of Phytopathology, v.36, p.59-90, 1998.

ISAAC, S. Fungal and plant interactions. Fungal-plant interactions. Cambridge: Chapman and Hall, 1992. 418p.

ISHII, H.; TOMITA, Y.; HORIO, T.; NARUSAKA, Y.; NAKASAWA, Y.; NISHIMURA, K.; IWAMOTO, S. Induced resistance of acibenzolar-S-methyl (CGA 245704) to cucumber and Japanese pear diseases. European Journal of Plant Pathology, v.105, p. 77-85, 1999.

JACOBS, A. K.; DRY, I. B.; ROBINSON, S. P. Induction of different pathogenesisrelated c-DNAs in grapevine infected with powdery mildew and treated with ethefon. Plant Pathology, v. 48, p.325-336, 1999.

JAGTAP, V.; BARGAVA, S. Variation in the antioxidant metabolism of drought tolerant and drought susceptible varieties of Sorghum bicolor (L.) Moench. exposed to high light, low water and high temperature stress. Journal of Plant Physiology, v. 145, p.195-197, 1995.

JAKAB, G.; COTTIER, V.; TOQUIN, V.; RIGOLI, G.; ZIMMERLI, R.; MÉTRAUX, J. P.; MAUCHI-MANI, B. $\beta$-Aminobutyric acid-induced resistance in plants. European Journal of Plant Pathology, v.107, n.1, p.29-37, 2001.

JORRIN, J.; DIXON, A. Stress responses in alfafa (Medicago sativa L.): II. Purification, characterization, and induction of phenylalanine ammonia-lyase isoforms from elicitor-treated cell suspension cultures. Plant Physiology, v.92, p.447-455, 1990. 
KAMIDA, H. M.; PASCHOLATI, S. F.; BELLATO, C. M. Influência de Saccharomyces cerevisiae na expressão gênica da fenilalanina amônia-liase em tecido de sorgo protegido contra Colletotrichum sublineolum. Summa Phytopathologica, v.26, n.1, p. 74-77, 2000.

KÄSTNER, B; TENHAKKEN, R.; KAUSS, H. Chitinase in cucumber hypocotyls is induced by germinating fungal spores and by fungal elicitor in synergism with inducers of acquired resistance. The Plant Journal, v.13, n.4, p. 447-454, 1998.

KIM, Y. C.; BLEE, K. A.; ROBINS, J.; ANDERSON, A. J. Oxycom TM under field and laboratory conditions increases resistance responses in plants. European Journal of Plant Pathology, v.107, n.1, p.129-136, 2001.

KIMATI, H.; BERGAMIN FILHO, A. Princípios gerais de controle. In: BERGAMIN FILHO, A.; KIMATI, H.; AMORIM, L. Manual de fitopatologia: princípios e conceitos. 3 .ed. São Paulo: Agronômica Ceres, 1995. v.1, cap. 22, p.417-453.

KNOESTER, M.; PIETERSE, C. M. J.; BOL, J. F.; VAN LOON, L. Systemic resistance in Arabidopsis induced by rhizobacteria requires ethylene-dependent signaling at the site of application. Molecular Plant-Microbe Interactions, v. 12, n.8, p.720727, 1999.

KOCH, W.; WAGNER, C.; SEITZ, U. Elicitor-induced cell death and phytoalexin synthesis in Daucus carota L. Planta, v.206, p.523-532, 1998.

KOFALVI, S. A.; NASSUTH, A. Influence of wheat streak mosaic virus infection on phenylpropanoid metabolism and the accumulation of phenolics and lignin in wheat. Physiological and Molecular Plant Pathology, v. 47, p. 365-377, 1995.

KOGANEZAWA, H.; SATO, T.; SASAYA, T. Effects of probenazole and saccharin in symptom appearance of tobacco mosaic virus in tobacco. Annals of Phytopathological Society of Japan, v.64, p.80-84, 1998. 
KOGEL, K. H.; HÜCKELHOVEN, R. Superoxide generation in chemically activated resistance of barley in response to inoculation with the powdery mildew fungus. Journal of Phytopathology, v.147, p.1-4, 1999.

KOLLÁR, R.; REIHNOLDS, B.; PETRÁKOVÁ, E.; YEH, J. C.; ASHWELL, G.; DRGONOVÁ, J.; KAPTEYN, J. C.; KLIS, F.; CABIB, E. Architecture of the yeast cell wall: $\beta$ (1-6) glucan interconnects mannoprotein, $\beta(1-3)$ glucan, and chitin. The Journal of Biological Chemistry, v.272, n.28, p. 17762-17775, 1997.

KOMBRINK, K.; SCHMELZER, E. The hypersensitive response and its role in local and systemic disease resistance. European Journal of Plant Pathology, v.107, n.1, p.69-78, 2001.

KOOMAN-GERSMANN, M.; HONEÉ, G.; BONNEMA, G.; DE WIT, P. J. M. A highaffinity binding site for the AVR9 peptide elicitor of Cladosporium fulvum is present on plasma membranes of tomato and other solanaceous plants. The Plant Cell, v. 8, p. 929-938, 1996.

KOZLOWISKI, G.; BUCHALA, A.; MÉTRAUX, J.P. Methyl jasmonate protects Norway spruce [Picea abies (L.) Karst.] seedlings against Pythium ultimum Trow. Physiological and Molecular Plant Pathology, v. 55, n.1, p. 53-58, 1999.

KUC, J. Induced systemic resistance - an overview. In: HAMMERSCHMIDT, R.; $\mathrm{KUC}$, J. (Ed.) Induced resistance to disease in plants. New York: Kluwer Academic, 1995. p. 169-175.

LEHNINGER, A. L. Bioquímica. São Paulo: Edgard Blücher, 1984. v.1. 256p.

LEITE, B.; RONCATTO, L. D. B.; PASCHOLATI, S. F.; LAMBAIS, M. R. Reconhecimento e transdução de sinais moleculares em interações planta-fungos patogênicos. Revisão Anual de Patologia de Plantas, v. 5, p.235-280, 1997. 
LEVER, M. A new reaction for colorimetric determination of carbohydrates. Analytical Biochemistry, v.47, p.273-279, 1972.

LIPKE, P., OVALLE, R. Cell wall architecture in yeast: New structure and new challenges. Journal of Bacteriology, v. 180, n.15, 1998.

LO, S. C.; DE VERDIER, K.; NICHOLSON, R. L. Accumulation of 3deoxyanthocyanidin phytoalexins and resistance to Colletotrichum sublineolum in sorghum. Physiological and Molecular Plant Pathology, v. 55, p. 263-273, 1999.

LORITO, M.; HARMAN, E; HAYES, C. K.; BROADWAY, R. M.; TRONSMO, A.; WOO, S. L.; Di PIETRO, A. Chitinolytic enzymes produced by Trichoderma harzianum: antifungal activity of purified endochitinase and chitobiosidase. Phytopatholgy, v.83, p.302-306, 1993.

LORITO, M.; WOO, S.; FRENANDEZ, I. G.; COLUCCI, G.; HARMAN, G. E.; PINTORTOROS, J.; FILIPPONE, E.; MUCCIFORA, S.; LAWRENCE, C. B.; ZOINA, A.; TUZUN, S.; SCALA, F. Genes from mycoparasitic fungi as a source for improving plant resistance to fungal pathogens. Proceedings of the National Academy of Science of the United States of America, v.95, p.7860-7865, 1998.

LOW, S. P.; SCHROEDER, A. T. Signal transduction pathways of the oxidative burst. In: STACEY, G.; KEEN, N. Plant-microbe interactions. New York: Chapman \& Hall, 1997. cap.3, p.53-75.

LUCAS, J.A. Plant immunization: from myth to SAR. Pesticide Science, v. 55, p. 193196, 1999.

MARLEY, P. S.; HILLOCKS, R. J. Effect of root-knot nematodes on cajanol accumulation in the vascular tissues of pigeonpea after stem inoculation with Fusarium udum. Plant Pathology, v. 43, p. 172-176, 1994. 
MAUCH-MANI, B.; MÉTRAUX, J.P. Salicylic acid and systemic acquired resistance to plant pathogen attack. Annals of Botany, v.82, p.535-540, 1998.

MCDOUGALL, G. J. Procedure for selection of cell-wall-associated glycoproteins. Phytochemistry, v.45, n.4, p.633-636, 1997.

MÉTRAUX, J. P. Systemic acquired resistance and salicylic acid: current state of knowledge. European Journal of Plant Pathology, v.107, n.1, p.13-18, 2001.

MOHR, P.; CAHILL, D. M. Relative roles of glyceollin, lignin and the hypersensitive response and the influence of $A B A$ in compatible and incompatible interactions of soybeans with Phytophthora sojae. Physiological and Molecular Plant Pathology, v. 58, p. 31-41, 2001.

MOLINA, A.; HUNT, D. M.; RYALS, J. A. Impaired fungicide activity in plants blocked in disease resistance signal transduction. The Plant Cell, v. 10, n.11, p. 1903-1914, 1998.

MONTEIRO JÚNIOR, O. A. Preparação, modificação química e colorimétrica do biopolímero quitosana. Campinas, 1999. p. 110. Tese (Doutorado) - Instituto de Química, Universidade Estadual de Campinas.

MORAES, M. G. Mecanismos da resistência sistêmica adquirida em plantas. Revisão Anual de Patologia de Plantas, v.6, p. 261-284, 1998.

MORAN, P. J.; CIPOLLINI, D. F. Effect of wind-induced mechanical stress on soluble peroxidase activity and resistance to pest in cucumber. Journal of Phytopathology, v. 147, p.313-316, 1999.

MURPHY, J. F.; GILLILAND, A.; WONG, C. E.; WEST, J.; SINGH, P.; CARR, J. P. Signal transduction in resistance to plant viruses. European Journal of Plant Pathology, v.107, n.1, p.121-128, 2001. 
NICHOLSON, R. L.; HAMMERSCHMIDT, R. Phenolic compounds and their role in disease resistance. Annual Review of Phytopathology, v. 30, p.369-389, 1992.

OGALLO, J. L.; McCLURE, M. A. Systemic acquired resistance and susceptibility to root-knot nematodes in tomato. Phytopathology, v.86, n.5, p. 498-501, 1996.

OLIVEIRA, R. F. Estudo do sistema de defesa constitutivo e induzido de Mimosa scabrella contra fungos. Curitiba, 1994. 106p. Dissertação (Mestrado) Universidade Federal do Paraná.

ONGENA, M.; DAAYF, F.; JAQUES, P.; THONART, P.; BENHAMOU, N.; PAULITZ, T. C.; BÉLANGER, R. R. Systemic induction of phytoalexins in cucumber in response to treatments with fluorescent pseudomonads. Plant Pathology, v. 49, p. 523-530, 2000.

OOSTENDORP, M.; KUNZ, W.; DIETRICH, B.; STAUB, T. Induced disease resistance in plants by chemicals. European Journal of Plant Pathology, v.107, n.1, p.19-28, 2001.

PAIVA, D. L.; LAMPMAN, G. M.; KRIZ, G. S. Introduction to spectroscopy: a guide for students of organic chemistry. New York: Sauders College, 1996. 512p.

PASCHOLATI, S.F. Potencial de Saccharomyces cerevisiae e outros agentes bióticos na proteção de plantas contra patógenos. Piracicaba, 1998. 123p. Tese (Livre Docência). Escola Superior de Agricultura "Luiz de Queiroz", Universidade de São Paulo.

PASCHOLATI, S. F.; LEITE, B. Hospedeiro: mecanismos de resistência. In: BERGAMIN FILHO, A.; KIMATI, H.; AMORIM, L. (Ed.) Manual de fitopatologia: princípios e conceitos. 3 .ed. São Paulo: Agronômica Ceres, 1995. v.1, cap. 22, p.417-453. 
PEIXOTO, P. H. P.; CAMBRAIA, J.; SANT'ANNA, R.; MOSQUIM, R.; MOREIRA, M. A. Aluminum effect on lipid peroxidation and on the activities of enzymes of oxidative metabolism in sorghum. Revista Brasileira de Fisiologia Vegetal, v.11, n. 3, p.137-143, 1999.

PHARMACIA. Affinity chromatography: principles \& methods. Sweden: Ljungforetagen, 1991. 112p.

RAMAMOORTHY, V.; VISWANATHATHAN, R.; RAGUCHANDER, T.; PRAKASAM, V.; SAMIYAPPAN, R. Induction of resistance by plant growth promoting rhyzobacteria in crop plants against pests and diseases. Crop Protection, v.20, p.1-11, 2001.

RAY, H.; DOUCHES, D. S.; HAMMERSCHMIDT, R. Transformation of potato with cucumber peroxidase: expression and disease response. Physiological and Molecular Plant Pathology, v.53, p.93-103, 1998.

RAY, H.; HAMMERSCHMIDT, R. Response of potato tuber to infection by Fusarium sambucinum. Physiological and Molecular Plant Pathology, v.53, p.81-92, 1998.

REPKA, V.; FISCHEROVÁ, I.; SILHAROVÁ, K. Biological activity of the elicitor released from mycelium of a grapevine isolate of the necrotrophic fungus Botrytis cinerea. Vitis, v. 40, n. 4, p.205-212, 2001.

$\mathrm{RICCl}, \mathrm{P}$. Induction of the hypersensitive response and systemic acquired resistance by fungal proteins: the case of elicitins. In: STACEY, G.; KEEN, N. Plant-microbe interactions. New York: Chapman \& Hall, 1997. cap.3, p.53-75.

RICCI, P.; PANABIERES, F.; BONNET, P.; MAIA, N.; PONCHET, M.; DEVERGNE, J. C.; MARAIS, A.; CARDIN, L.; MILAT, M. L.; BLEIN, J. P. Proteinaceous elicitors of plant defense responses. Oligossacharide elicitors: structure and recognition. In: INTERNATIONAL CONFERENCE OF EUROPEAN FOUNDATION FOR PLANT PATHOLOGY. 2., Strasbourg, 1993. Proceedings. Dordrecht: Kluwer Academic, 1993. p. 121-135. 
RICHARD-MOLARD, C.; WUILLÈME, S.; SCHEEL, C.; GRESSHOFF, P. M., MOROTGAUDRY, J. F; LIMAMI, A. M. Nitrogen-induced changes in morphological development and bacterial susceptibility of belgian endive (Cichorium intybus L.) are genotype-dependent. Planta, v.209, p. 386-398, 1999.

RONCATO, M. C.; PACHOLATI, S. F. Alterações na atividade e no perfil eletroforético da peroxidase em folhas de milho (Zea mays) e sorgo (Sorghum bicolor) tratadas com levedura (Saccharomyces cerevisiae). Scientia Agricola, v. 55, n.3, p. 395402, 1998.

SAFESCIENCE. Elexa. http://www.safescience.com/agriculture/elexasmart.html. (21 dec. 2001).

SARIG, P.; ZUTKHI, Y.; MONJAUZE, A.; LISKER, N.; BEM-ARIE, R. Phytoalexin elicitation in grape berries and their susceptibility to Rhizopus stolonifer. Physiological and Molecular Plant Pathology, v. 50, p.337-347, 1997.

SCHAFFRATH, U.; SCHEINPFLUG, H.; REISSENER, H. J. An elicitor from Pyricularia oryzae induces resistance responses in rice: isolation, characterization and physiological properties. Physiological and Molecular Plant Pathology, v.46, p.293-307, 1995.

SCHOBER, B.; VERMEULEN, T. Enzymatic maceration of witloof chicory by the soft rot bacteria Erwinia carotovora subsp. carotovora: the effect of nitrogen and calcium treatments of the plant on pectic enzyme production and disease development. European Journal of Plant Pathology, v. 105, p.341-349, 1999.

SCHWEIZER, P.; KMECL, A.; CARPITA, N.; DUDLER, R. A solube carbohydrate elicitor from. Blumeria graminis $\mathrm{f}$. $\mathrm{sp}$. tritici is recognized by a broad range of cereals. Physiological and Molecular Plant Pathology, v. 56, n.4, p.157-167, 2000. 
SÉJALON-DELMAS, N.; MATEOS, F. V.; BOTTIN, A.; RICKAUER, M.; DARGENT, R.; ESQERRÉ-TUGAYÉ, M. T. Purification, elicitor activity, and cell wall localization of a glycoprotein from Phytophthora parasitica var. nicotianae, a fungal pathogen of tobacco. Phytopathology, v. 87, n.9, p.899-909, 1997.

SHIRAISHI, T.; YAMADA, T.; ICHINOSE, Y.; KIBA, A.; TOYODA, K.; KATO, T.; MURAKAMI, Y.; SEKI, H. Suppressor as a factor determining plant-pathogen specificity. In: STACEY, G.; KEEN, N. T. (Ed.) Plant-microbe interactions. New York: Chapman \& Hall, 1997. v.4, cap. 5, p.121-161.

SHULAEV, V.; SILVERMAN, P.; RASKIN, I. Airborne signalling by methyl salicylate in plant pathogen resistance. Nature, v. 385, n.6618, p. 718-721, 1997.

SIEGRIST, J.; JEBLICK, W.; KAUSS, H. Defense responses in infected and elicited cucumber (Cucumis sativus L.) hypocotyl segments exhibiting acquired resistance. Plant Physiology, v.105, n.4, p. 1365-1374, 1994.

SILVERSTEIN, R. M.; BASSLER, G. C.; MORRILL, T. C. Identificação espectrométrica de compostos orgânicos. Rio de Janeiro: Guanabara Dois, 1979. 299p.

SLOVÁKOVA, L.; LISKOVA, D.; CAPEK, P.; KUBACKOVÁ, M.; KÁKONIOVÁ, D.; KARACSONYI, S. Defense responses against TNV inffection induced by galactoglucomannan-derived oligosaccharides in cucumber cells. European Journal of Plant Pathology, v. 106, p. 543-553, 2000.

SNOEIJERS, S.; PÉREZ-GARCIA, A.; JOOSTEN, M. H. A. J.; de WITT, P. J. G. M. The effect of nitrogen on disease development and gene expression in bacterial and fungal plant pathogens. European Journal of Plant Pathology, v.106, p.493-506, 2000.

SNYDER, B.; NICHOLSON, R.L. Synthesis of phytoalexins in sorghum as a site response to fungal ingress. Science, v.248, p.1637-1639, 1990. 
SPLETZER, M.; ENYEDI, A.J. Salicylic acid induces resistance to Alternaria solani in hydroponically grown tomato. Phytopathology, v.89, n.9, p. 722-727, 1999.

STAUB, T. Fungicide resistance: practical experience with antiresistance strategies and the role of integrated use. Annual Review of Phytopathology, v.29, p. 421442, 1991.

STEIN, B. D.; KLOMPARENNS, K.; HAMMERSCHMIDT, R. Histochemistry and ultrastructure of the induced resistance response of cucumber plants to Colletotrichum lagenarium. Journal of Phytopatology, v.137, p. 177-188, 1993.

STERMER, B. A. Molecular regulation of systemic induced resistance. In: HAMMERSCHMIDT, R.; KUC, J. (Ed.) Induced resistance to disease in plants. New York: Kluwer Academic, 1995. p. 111 - 140.

STEVENS, C.; KHAN, V. A.; LU, J. Y.; WILSON, C. L.; ADEYEYE, O.; PUSEY, L. P.; TANG, A. Y. A. Induced resistance of sweetpotato to Fusarium root rot by UV-C hormesis. Crop Protection, v.18, p. 463-470, 1999.

STICHER, L.; MÉTRAUX, J. P. Inhibitors of Nlinked glycosylation induce systemic acquired resistance in cucumber. Physiological and Molecular Plant Pathology, v. 56, p. $245-252,2000$.

STICHER, L.; MAUCHI-MANI, B.; METRAUX, J. P. Systemic acquired resistance. Annual Review of Phytopathology, v. 35, p.235-270, 1997.

STRACK, D. Phenolic metabolism. In: DEY, P. M.; HARBORNE, J. B. (Ed.). Plant biochemistry. London: Academic Press, 1997. cap.10, p.387-416.

SVALHEIM, O.; ROBERTSEN, B. Elicitation of $\mathrm{H}_{2} \mathrm{O}_{2}$ in cucumber hypocotyl segments by oligo-1,4- $\alpha$-D-galacturonides and an oligo- $\beta$-glucan preparation from cell walls of Phytophthora megasperma f.sp. glycinea. Physiologia Plantarum, v. 88, p. 675681, 1993. 
TENHAKEN, R.; LEVINE, A.; BRISSON, L. F.; DIXON, R. A.; LAMB, C. Function of the oxidative burst in hypersensitive disease resistance. Proceedings of the National Academy of Science of the United States of America, v.92, p.41584163, 1995.

TUZUN, S. The relationship between pathogen-induced systemic resistance (ISR) and multigenic (horizontal) resistance in plants. European Journal of Plant Pathology, v.107, n.1, p.39-50, 2001.

UMEMOTO, N.; KAKITANI, M.; IWAMATSU, A.; YOSHIKAWA, M.; YAMAOKA, N.; ISHIDA, I. The structure and function of a soybean $\beta$-glucan-elicitor-binding protein. Proceedings of the National Academy of Science of the United States of America, v.94, p.1029-1034, 1997.

VAN DER ACKERVEKEN, G. F. J. M.; DE WIT, P. J. G. M. The Cladosporium fulvum - tomato interaction, a model system for fungus-plant specificity. In: KOHMOTO, K.; SINGH, U. S.; SINGH, R. P. (Ed.) Pathogenesis and host specificity in plant diseases: histopathological, biochemical, genetic and molecular bases. Oxford: Pergamon, 1995. v. 2, cap.9, p.145-160.

VAN LOON, L.C.; VAN STRIEN, E.A. The families of pathogenesis-related proteins, their activities, and comparative analysis of PR-1 type proteins. Physiological and Molecular Plant Pathology, v. 55, p. 85-97, 1999.

VAN LOON, L.C.; PIETERSE, C. M. J.; BAKKER, P. A. H. M.; GERAATS, B. M. P.; KNOESTER, M.; TON, J.; VAN WEES, S. C. M. Systemically induced resistance in arabidopsis. In: CONGRESSO BRASILEIRO DE FITOPATOLOGIA, 34., São Pedro, 2001. Fitopatologia Brasileira, v.26, p.254, 2001. (Suplemento).

VANETTEN, H.; TEMPORINI, E.; WASMANN, C. Phytoalexin (and phytoanticipin) tolerance as a virulence trait: why is it not required by all pathogens? Physiological and Molecular Plant Pathology, v. 59, p.83-93, 2001. 
WALTON, J. D. Biochemical plant pathology. In: DEY, P. M.; HARBORNE, J. B. Plant biochemistry. London: Academic Press, 1997. cap.13, p.487-502.

WATTAD, C.; DINOOR, A.; PRUSKY, D. Purification of pectate lyase produced by Colletotrichum gloeosporioides and its inhibition by epicatechin: a possible factor involved in the resistance of unripe avocado fruits to anthracnose. Molecular Plant-Microbe Interactions v. 7, n. 2, p.293-297, 1994.

WEI, Z. M.; LABY, R. J.; ZUMOFF, C. H.; BAUER, D. W.; HE, S. Y.; COLLMER, A.; BEER, S. V. Harpin, elicitor of the hypersensitive response produced by the plant pathogen Erwinia amylovora. Science, v. 257, p. 85-88, 1992.

WHARTON, P. S.; NICHOLSON, R. L. Temporal synthesis and radiolabelling of the sorghum 3-deoxyanthocyanidin phytoalexins and the anthocyanin, cyanidin 3dimalonil glucoside. New Phytologist, v. 145, p. 457-469, 2000.

WULFF, N. A. Caracterização parcial de elicitores de fitoalexinas em sorgo (Sorghum bicolor) obtidos a partir de Saccharomyces cerevisase. Piracicaba, 1997. 62p. Dissertação (Mestrado) - Escola Superior de Agricultura "Luiz de Queiroz", Universidade de São Paulo.

WULFF, N. A.; PASCHOLATI, S. F. Partial characterization of sorghum phytoalexin elicitors isolated from Saccharomyces cerevisiae. Fitopatologia Brasileira, v.24, n.3, p. 428-435, 1999.

WURMS, K.; LABBÉ, C.; BENHAMOU, N.; BÉLANGER, R. R. Effects of Milsana and Benzothiadizole on the ultrastruture of powdery mildew haustoria on cucumber. Phytopathology, v.89, n.9, p. 728-736, 1999.

YAMAMOTO, M.; NAKATSUKA, S.; OTANI, H.; KOHMOTO, K.; NISHIMURA, S. (+)Catechin acts as an infection-inhibiting factor in strawberry leaf. Phytopathology, v.90, n.6, p. 595-600, 2000. 
ZEHNDER, G. W.; MURPHY, J. F.; SIKORA, E. J.; KLOEPPER, J. W. Application of rhizobacteria for inducced resistance. European Journal of Plant Pathology, v. 107, n. 1, p. 39-50, 2001. 
APÊNDICES 
APÊNDICE 1 - Soluções usadas para regeneração das resinas de cromatografia: sequência de uso, concentrações e volumes.

\section{DEAE-Celulose}

\begin{tabular}{|c|c|c|c|}
\hline & Reagente & Concentração (M) & Volume (mL) \\
\hline $1^{\circ}$ & Água & - & 100 \\
\hline $2^{\circ}$ & $\mathrm{NaOH}$ & 0,10 & 160 \\
\hline $3^{\circ}$ & Água & - & 100 \\
\hline $4^{\circ}$ & $\mathrm{HCl}$ & 0,10 & 160 \\
\hline $5^{\circ}$ & Água & - & 100 \\
\hline $6^{\circ}$ & Tris- $\mathrm{HCl}(\mathrm{pH} 8,0)$ & 0,05 & 100 \\
\hline $7^{\circ}$ & Tris- $\mathrm{HCl}(\mathrm{pH} 8,0)$ & 0,01 & 200 \\
\hline
\end{tabular}

\section{Con-A}

\begin{tabular}{|c|c|c|c|}
\hline & Reagente & Concentração (M) & Volume $(\mathbf{m L})$ \\
\hline $1^{\circ}$ & Tris- $\mathrm{HCl}(\mathrm{pH} \mathrm{8,5)}$ & 0,10 & 120 \\
\hline $2^{\circ}$ & $\begin{array}{c}\text { Tampão acetato }(\mathrm{pH} \\
4,5)+0,5 \mathrm{M} \mathrm{NaCl}\end{array}$ & 0,10 & 120 \\
\hline $3^{\circ}$ & Tampão Con-A & 0,02 & 120 \\
\hline
\end{tabular}


APÊNDICE 2 - (a). Curva padrão para a dosagem de proteínas através do método de Bradford; (b). Curva padrão para a dosagem de carboidratos redutores através do método de Lever; (c). Curva padrão para a dosagem de fenóis através do método de Folin-Cicalteau.
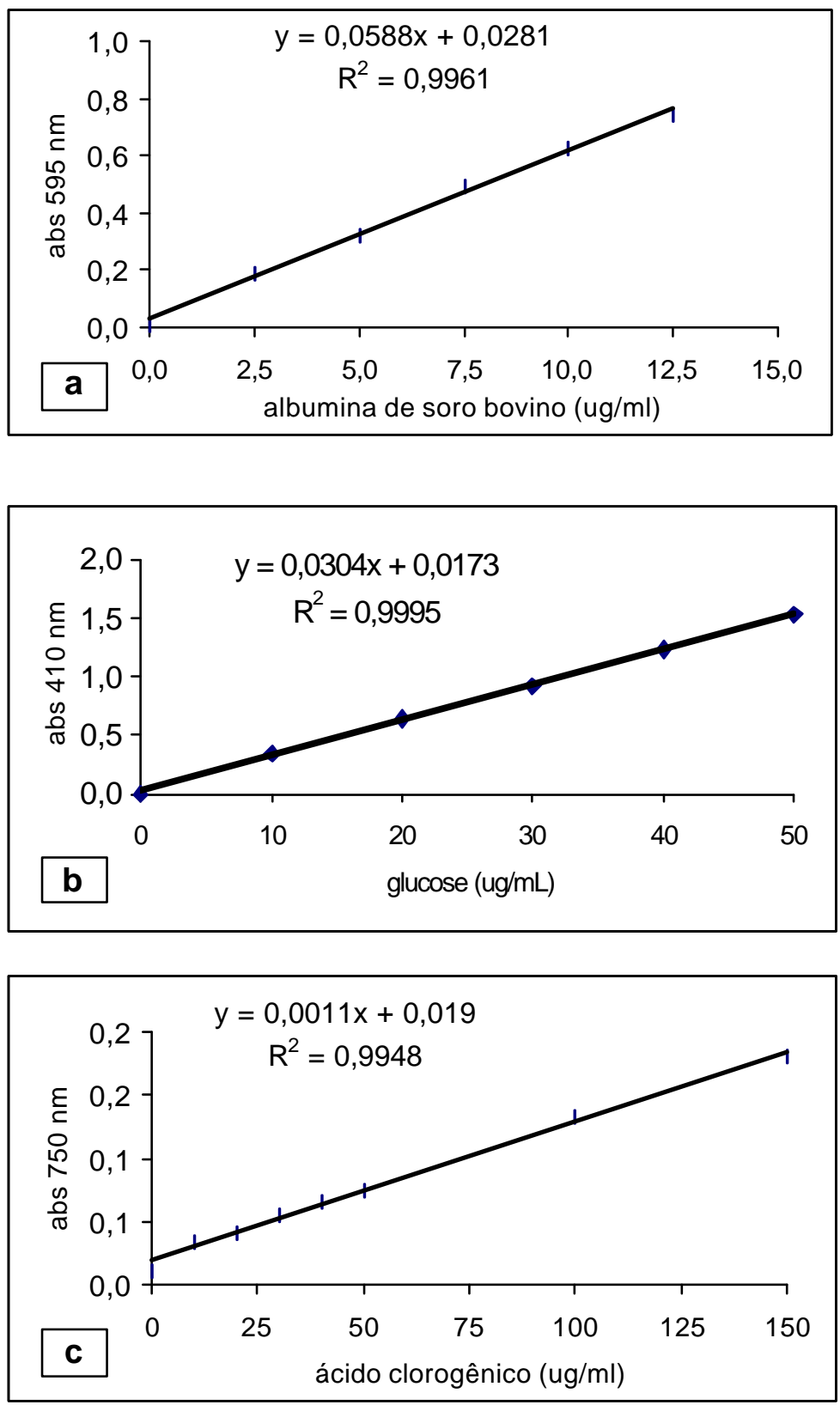
APÊNDICE 3 - Estruturas de carboidratos

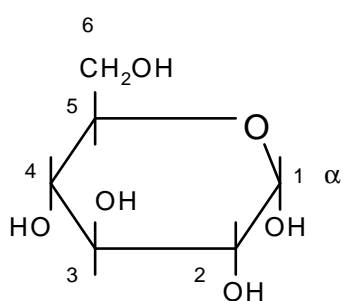

$\alpha$ - D- glucose

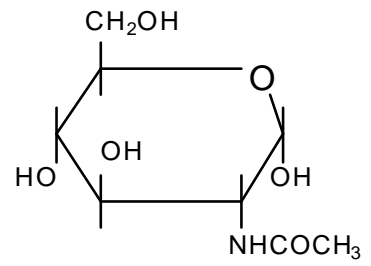

$N$-acetilglucosamina

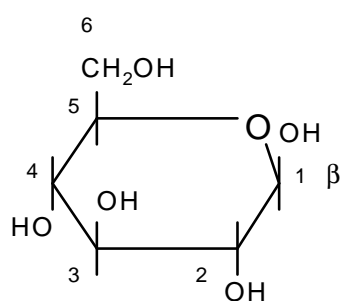

$\beta$ - D-glucose

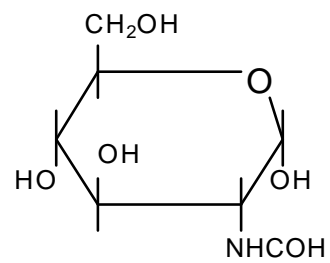

glucosamina

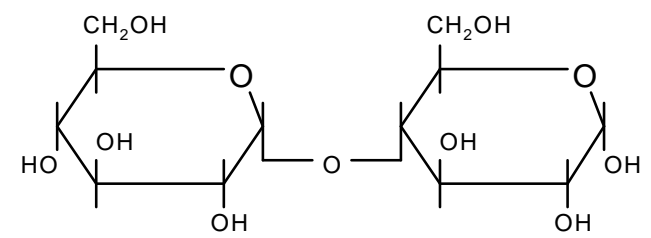

Duas moléculas de glicose, unidas por laço glicosídico $\alpha-1,4$

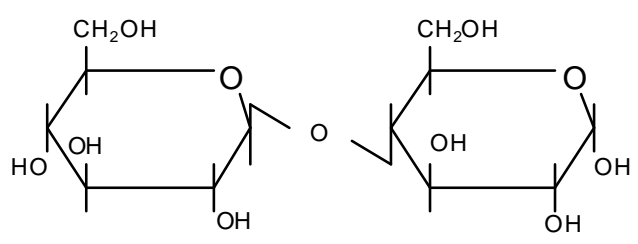

Duas moléculas de glicose, unidas por laço glicosídico $\beta-1,4$ 